\title{
AVALIAÇÃO DE PARÂMETROS MINERAIS E DETERMINAÇÃO DAS NORMAS DRIS DO CAPIM TANZÂNIA
}

\author{
Roberto Naves Souza Aguiar
}

Dissertação apresentada à Escola Superior de Agricultura "Luiz de Queiroz", Universidade de São Paulo, para obtenção do título de Mestre em Agronomia, Área de Concentração: Ciência Animal e Pastagens.

PIR A C I C A B A

Estado de São Paulo - Brasil

Abril - 2004 


\title{
AVALIAÇÃO DE PARÂMETROS MINERAIS E DETERMINAÇÃO DAS NORMAS DRIS DO CAPIM TANZÂNIA
}

\author{
Roberto Naves Souza Aguiar \\ Engenheiro Agrônomo
}

Orientador: Prof. Dr. MOACYR CORSI

Dissertação apresentada à Escola Superior de Agricultura "Luiz de Queiroz", Universidade de São Paulo, para obtenção do título de Mestre em Agronomia, Área de Concentração: Ciência Animal e Pastagens.

P I R A C I C A B A

Estado de São Paulo - Brasil

Abril - 2004 


\section{Dados Internacionais de Catalogação na Publicação (CIP) DIVISÃO DE BIBLIOTECA E DOCUMENTAÇÃO - ESALQ/USP}

Aguiar, Roberto Naves Souza

Avaliação de parâmetros minerais e determinação das normas DRIS do capim

Tanzânia / Roberto Naves Souza Aguiar. - - Piracicaba, 2004.

$148 \mathrm{p}$.

Dissertação (mestrado) - - Escola Superior de Agricultura Luiz de Queiroz, 2004.

Bibliografia.

1. Adubação 2. Capim - Tanzânia 3. Diagnose foliar 4. Irrigação 5. Nutrição vegetal Pastagens 7. Pastejo (Manejo) I. Título

CDD 633.2

"Permitida a cópia total ou parcial deste documento, desde que citada a fonte - O autor" 
Ao professor

Moacyr Corsi

Dedico

Ofereço aos meus pais

Antônio Alberto Aguiar

e Maria Augusta Naves Aguiar

“... Oh Escola! Oh flor da montanha! Oh insigne "Luiz de Queiroz"! Tua história é uma força tamanha, que nos faz avançar mais veloz."

“... Eia, pois, esalqueanos, sem guerra! Co'a bandeira da Escola na mão, ensinai que plantar nesta terra é lutar pela grande Nação!"

Ode à ESALQ - Salvador de Toledo Piza Jr. (1921) 


\section{AGRADECIMENTOS}

- $\quad$ Ao meu irmão Rodrigo e minhas irmãs Ana e Letícia, pelo apoio.

- Ao Prof. Dr. Moacyr Corsi pela amizade e orientação na condução das atividades.

- Ao Prof. Dr. Luis Gustavo Nussio, pelo incentivo e inspiração na área acadêmica.

- $\quad$ Aos colegas de pós-graduação Miguel Menezes e Fabio Maya pela ajuda na condução do trabalho de campo e coordenação do Projeto CAPIM.

- $\quad$ Aos Eng. Agr. Marco Balsalobre e Marco Penati, pelas sugestões para a melhor condução desse trabalho.

- $\quad$ Aos estagiários do Projeto CAPIM, pois sem eles esse trabalho não teria sido realizado.

- $\quad$ Ao amigo Miguel da Rocha Cavalcanti, pelo exemplo de dedicação.

- Ao Eng. Agr. Miguel José Thomé Menezes, pelo companheirismo e amizade.

- Ao Eng. Agr. Cláudio Melo, pelo auxilio na execução das análises estatísticas.

- Aos Amigos e colegas do Ano Xorão (turma centenário), pela alegria e fraternidade dos momentos em conjunto.

- $\quad$ A república Tipo Zero Uai, pelos ensinamentos indispensáveis a formação pessoal e profissional. 


\section{SUMÁRIO}

Página

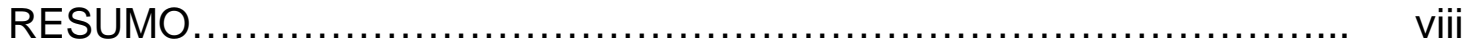

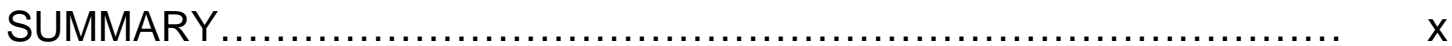

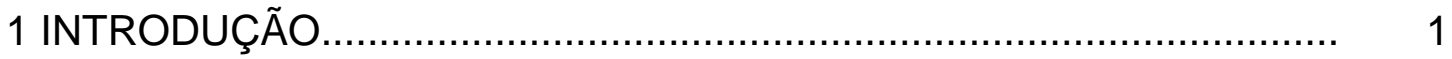

2 REVISÃO BIBLIOGRAFICA............................................................ 4

2.1 Efeito dos nutrientes nas forrageiras............................................... 4

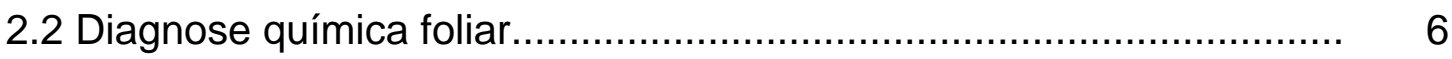

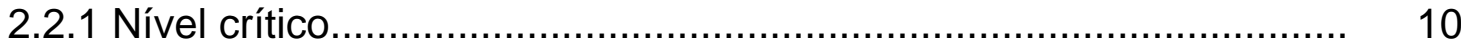

2.2.2 Faixa de suficiência.................................................................. 13

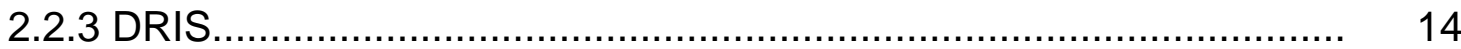

2.3 Fatores que influenciam a nutrição............................................... 20

2.3.1 Fatores climáticos.................................................................... 20

2.3.2 Fatores físicos do solo........................................................... 21

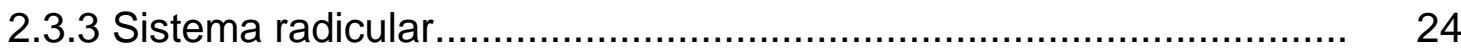

2.3.4 Relação entre nutrientes............................................................. 26

2.3.4.1 Potássio, magnésio e cálcio …………….............................. 26

2.3.5 Reciclagem de nutrientes...................................................... 27

2.3.5.1 Consumo e extração................................................................ 28

2.3.5.2 Vias de reciclagem.............................................................. 29

2.3.5.2.1 Via excreções................................................................... 31

2.3.5.2.2 Via forragem................................................................... 35

2.3.6 Nutrição da planta.................................................................... 39

3 MATERIAL E MÉTODOS............................................................... 42 
3.1 Primeiro ano experimental........................................................ 42

3.1.1 Local do experimento................................................................. 42

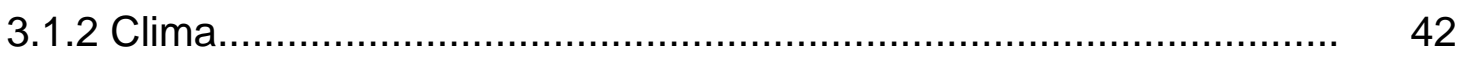

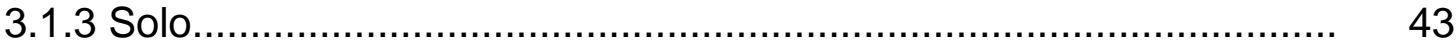

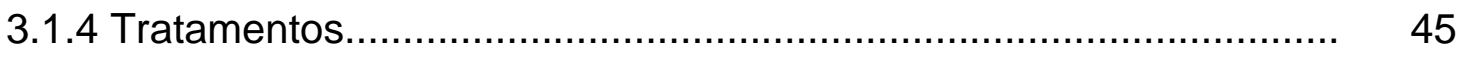

3.1.5 Instalação e condução do experimento........................................... 45

3.1.6 Análise estatística ................................................................... 52

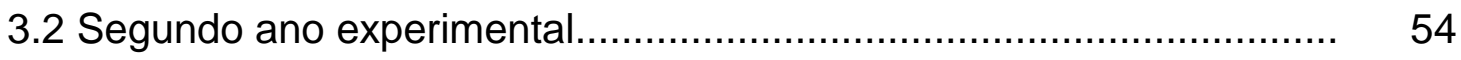

3.2.1 Local do experimento......................................................... 54

3.2.2 Clima

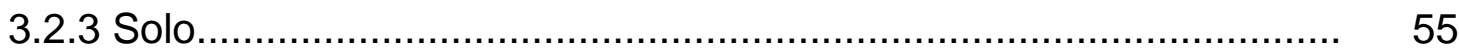

3.2.4 Instalação e condução do experimento.......................................... 55

3.3 Análise de terra e da planta............................................................ 58

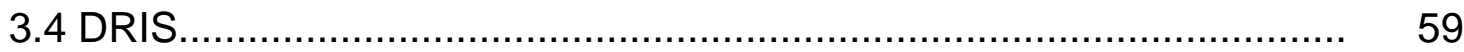

3.4.1 Métodos de cálculo do DRIS .................................................. 59

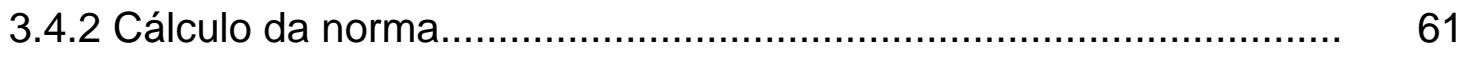

3.4.3 Validação da norma DRIS......................................................... 63

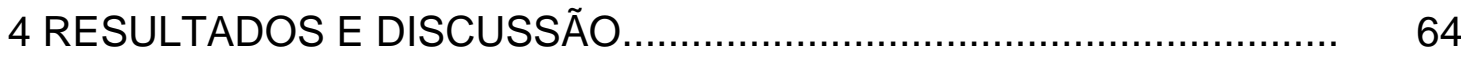

4.1 Concentração dos minerais em diferentes partes do capim

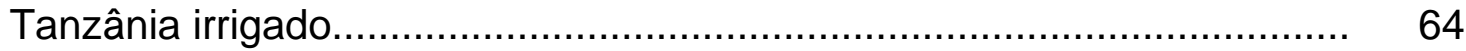

4.2 Pastejo simulado, consumo e reciclagem de nutrientes..................... 90

4.3 Cálculo e validação das normas DRIS .............................................. 100

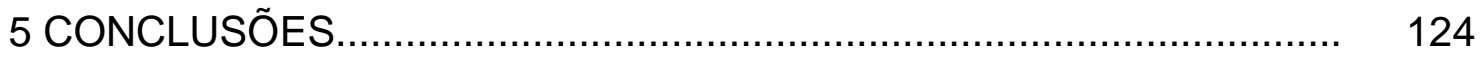

REFERÊNCIAS BIBLIOGRÁFICAS................................................ 126 


\title{
LISTA DE ABREVIATURAS E SÍMBOLOS
}

\author{
FE - Folha em expansão \\ LFRE - Lâmina de folha recém expandida \\ LFM - Lâmina de folha madura \\ $\mathrm{CB}$ - Colmo mais bainha \\ PT - Planta toda
}




\title{
AVALIAÇÃO DE PARÂMETROS MINERAIS E DETERMINAÇÃO DAS NORMAS DRIS DO CAPIM TANZÂNIA
}

\author{
Autor: ROBERTO NAVES SOUZA AGUIAR \\ Orientador: Prof. Dr. MOACYR CORSI
}

\section{RESUMO}

O objetivo desta pesquisa foi avaliar o efeito do manejo do pastejo e do período sobre a concentração dos minerais em diferentes partes da forrageira e sobre o consumo e reciclagem dos minerais por meio do pastejo. $O$ experimento foi realizado de outubro de 1999 a outubro de 2000 em um sistema de pastejo rotacionado em área irrigada de Panicum maximum Jacq. cv. Tanzânia estabelecidas na ESALQ, Piracicaba, SP. O delineamento foi em blocos (4) completos ao acaso com três massas de forragem pós-pastejo $(1.000,25.000$ e $4.000 \mathrm{~kg} / \mathrm{ha}$ de massa seca verde (MSV)), caracterizados, respectivamente, como tratamentos de alta, média e baixa intensidade de pastejo. O período de coleta apresentou diferenças nas concentrações dos minerais em diferentes partes da forrageira. As menores concentrações de nitrogênio e fósforo nas partes analisadas foram observadas no período 01 (30/10/1999 a 14/02/2000), correspondente a primavera e verão. A concentração de potássio variou na maioria das partes analisadas entre os períodos experimentais, sendo os menores valores encontrados no período 02 (15/02/2000 a 01/06/2000). Para o cálcio, ocorreu variação nas concentrações 
de LFRE (lâmina de folha recém-expandida) e LFM (lâmina de folha madura) entre os períodos ocorrendo maiores valores no período 02. As maiores concentrações de magnésio e enxofre ocorreram no período 03 (02/06/2000 a 23/10/2000). Por outro lado, a intensidade de pastejo demonstrou pouca influência sobre a concentração dos minerais na planta, ocorrendo, na maioria das vezes, apenas diferenças na concentração da LFM, como nos casos do $\mathrm{N}$, $\mathrm{P}, \mathrm{S}$ e $\mathrm{Zn}$, sendo que estes apresentaram maiores concentrações na LFM no tratamento de alta intensidade. O aumento da intensidade determinou aumento do consumo animal de minerais, com valores de $44,9 \mathrm{~kg} \mathrm{~N} ; 4,0 \mathrm{~kg} \mathrm{P} ; 54,2 \mathrm{~kg} \mathrm{~K}$; 6,1 kg Ca; 8,3 kg Mg e 2,6 kg S por hectare, por ciclo de pastejo, no tratamento de alta intensidade. Do mesmo modo, maiores quantidade e porcentagem de minerais contidos na forragem pré-pastejo retornaram ao solo via fezes e urina quando a pastagem foi manejada com alta intensidade. Assim, as diferenças entre consumo e reciclagem de minerais de acordo com a intensidade de pastejo podem determinar diferenças nas adubações. A partir das determinações desse primeiro ano experimental, e das coletas de forragem do segundo ano experimental, entre fevereiro de 2002 e janeiro de 2003, em áreas irrigadas e de sequeiro estabelecidas com capim Tanzânia, foi determinada a norma DRIS para o capim Tanzânia. O método DRIS, com base nas normas determinadas a partir de uma população de alta produção, demonstrou-se acurado para diagnosticar as amostras de tecido foliar como deficientes, equilibradas e excessivas. No entanto, existiu pouca relação entre IBN (índice de balanço nutricional) e produção de massa seca. Quanto aos métodos utilizados para cálculo das funções, o proposto por Jones (1981) demonstrou menores variações entre os índices DRIS e não apresentou relação do IBN com a produção de massa seca, o que determinou a indicação dos métodos propostos por Beaufils (1973) e Elwali \& Gascho (1984) para o cálculo do índice DRIS. 


\section{MINERAL PARAMETERS EVALUATION AND DRIS NORMS FOR PANICUM MAXIMUM JACQ. CV TANZÂNIA}

Author: ROBERTO NAVES SOUZA AGUIAR

Adviser: Prof. Dr. MOACYR CORSI

\section{SUMMARY}

The objective of this research was to evaluate the effects of grazing management and season of the year on mineral concentrations in four parts of Panicum maximum Jacq. cv. Tanzânia (EL - expanded leaf, RELB - recent expanded leaf blades, MLB - mature leaf blades and SS - stems plus sheaths), and on mineral intake and recycling through grazing cattle. One experiment was done from October 1999 to October 2000 on an irrigated area under rotational grazing. Treatments imposed were three post-grazing residues, 1000, 2500 and $4000 \mathrm{Kg} / \mathrm{ha}$ of green dry matter, respectively in a four randomized complete blocks design. Season of the year affected mineral concentrations in every part of the plant. From October till beginning of February (period 1) there was low concentration of nitrogen and phosphorous in all parts of the plant. Potassium concentrations varied among season of the year; its lowest concentrations occurred from February to May (period 2). Calcium concentration of the RELB and MLB, also varied along seasons of the year occurring highest values in period 2. The highest concentrations of magnesium and sulphur occurred for 
June to October (period 3). Grazing intensity had small influence on plant mineral concentrations. The MLB showed higher concentrations of $\mathrm{N}, \mathrm{P}, \mathrm{S}$ and $\mathrm{Zn}$ on the low post-grazing residue. Mineral intake was higher on the low postgrazing residue; intake levels during one grazing cycle at the low post-grazing residue were $44.9 \mathrm{~kg} \mathrm{~N} ; 4.0 \mathrm{~kg} \mathrm{P} ; 54.2 \mathrm{~kg} \mathrm{~K} ; 6.1 \mathrm{~kg} \mathrm{Ca} ; 8.3 \mathrm{~kg} \mathrm{Mg}$ e $2.6 \mathrm{~kg}$ S per hectare. A higher mineral percentage of the pre-grazing forage mass was returned to the soil via feces and urine when the pasture was managed with low post-grazing residue. Differences between intake and mineral recycling related to the grazing intensity can be used to establish the adequate fertilization for pasture maintenance and production. The DRIS norms for the Tanzania grass were determined using data colleted during two periods: October 1999 through October 2000 and February 2002 through January 2003. The DRIS method, based on the established norms, was accurate to diagnose deficiencies, balance and excess nutrients in leaf tissue. There was a low relationship between NBI (Nutritional Balance Index) and dry matter yield. The method proposed by Jones (1981) showed smaller variations between DRIS indexes and showed no relationship between NBI and dry matter yield. Methods proposed by Beaufils (1973) and Elwali \& Gascho (1984) were more suitable to estimate DRIS index. 


\section{INTRODUÇÃO}

O agronegócio tem grande participação na economia brasileira, representando 29\% do PIB brasileiro em 2002, sendo que o setor agropecuário representou $8,5 \%$ do PIB, e, destes, a pecuária contribuiu com 42\% (CEPEA, 2003). Além disso, a cadeia de agronegócio da pecuária emprega 20 milhões de pessoas (CNA, 2003).

Segundo dados do Ministério da Agricultura, Pecuária e Abastecimento (2004), a exportação de carne bovina superou 1,3 milhão de toneladas em equivalente carcaça, colocando o Brasil como o maior exportador mundial em 2003. A expectativa da ABIEC \& CNA (2004) para 2004 é de 1,4 milhão de toneladas em equivalente carcaça destinado à exportação e uma produção nacional de 7,8 milhões de toneladas em equivalente carcaça.

No entanto, nas últimas décadas, verificou-se expansão de culturas como cana-de-açúcar, citros, soja e cereais no Estado de São Paulo. Por outro lado, as áreas de pastagens, as quais eram exploradas de maneira extrativista, perdiam competitividade em relação a culturas tecnificadas, como alternativa de uso da terra (Faria et al., 1997). Assim, entre 1991 e 2001, a área de pastagem do Estado de São Paulo foi reduzida em 165 mil hectares, enquanto as áreas de cana-de-açúcar e de citros cresceram, respectivamente, 950 mil e 128 mil hectares (IEA, 2002).

Neste cenário, a intensificação da pecuária parece ser uma necessidade imperativa, sendo que a adubação de pastagens assume papel de destaque nesse processo, uma vez que a ausência de fertilização leva à exploração extrativista das áreas de pastagens, resultando no empobrecimento dos solos e 
na degradação das pastagens. Manejo e adubações adequados possibilitam altas produções de forragem, com qualidade superior, gerando benefícios na produtividade animal (Andrade et al., 1996).

Neste contexto, além da adubação, a produção de bovinos em pastagens irrigadas é uma tecnologia que tem sido crescentemente adotada pelos pecuaristas. Esta se apóia, principalmente, em dois objetivos, o de minimizar os efeitos da estacionalidade da produção e o de produzir maior quantidade e melhor qualidade de forragem durante $o$ ano.

A aumento na quantidade e qualidade de matéria seca em pastagens irrigadas e adubadas tem importância decisiva para aumentar em até dez vezes a atual produtividade animal. Trabalhos em pastagens irrigadas na Escola Superior de Agricultura "Luiz de Queiroz" têm demonstrado produtividade animal acima de $1.500 \mathrm{~kg}$ P.V. (peso vivo)/ha ano, enquanto a média de produtividade nacional é $150 \mathrm{~kg}$ P.V./ha ano (Penati, 2002).

Nesse cenário, a avaliação do estado nutricional das plantas cultivadas tem sido um dos grandes desafios em fertilidade do solo e nutrição de plantas em todo o mundo. No Brasil, o desafio se torna ainda maior em razão da necessidade de produção de alimentos em solos altamente intemperizados e de baixa fertilidade natural, predominantes nas regiões tropicais, conciliado à necessidade de otimizar os recursos de fertilidade em função dos custos.

Desse modo, estudos relacionados à composição mineral de plantas forrageiras têm grande importância para a interpretação de análise foliar com o objetivo de orientar níveis de adubação e possíveis inter-relações na absorção, translocação ou metabolismo desses nutrientes na planta (Corsi \& Nussio, 1994). Além disso, esses estudos têm importância no sentido de orientar decisões sobre manejo do solo e da adubação com o objetivo de garantir a perenidade e aumentar a produtividade da forragem.

Pesquisas em nutrição de plantas forrageiras sob pastejo intensivo em áreas irrigadas são escassas tanto no Brasil como em regiões com condições tropicais, demonstrando a necessidade de estudos nessa área. Este trabalho 
teve como objetivo avaliar o efeito do manejo do pastejo e do período de coleta sobre a concentração dos minerais em diferentes partes do capim Tanzânia, irrigado e adubado ao longo dos ciclos de pastejo, sobre o consumo e reciclagem dos minerais. Através destas determinações, foi estabelecida a norma DRIS para capim Tanzânia. 


\section{REVISÃO BIBLIOGRÁFICA}

\subsection{Efeito dos nutrientes nas forrageiras}

Trabalhos realizados por Mattos \& Werner (1979), Corrêa et al. (1996), Colozza (1998) e Manarin (2000) verificaram que as produções de massa seca de Panicum maximum aumentaram com a elevação das doses de nitrogênio. Nesse sentido, entre os macronutrientes, o nitrogênio e o potássio possuem importante papel para a nutrição das plantas. No caso do nitrogênio, por ser constituinte essencial das proteínas e interferir diretamente no processo fotossintético por sua participação na molécula de clorofila. No caso do potássio, por ser o cátion em maior concentração nas plantas, sendo um nutriente com relevantes funções fisiológicas e metabólicas como ativação de enzimas, fotossíntese, translocação de assimilados e, também, absorção de nitrogênio e síntese protéica, sendo, assim, limitantes em sistemas de utilização intensiva do solo (Andrade et al., 1996).

Segundo Mesa et al. (1989), o potássio tem grande influência no metabolismo, apesar de nem sempre apresentar efeitos marcantes na produção de massa seca, mas sua presença, em concentração adequada, é necessária, principalmente em exploração intensiva de pastagens. Nesse caso, Andrade et al. (2000) determinaram que as melhores respostas à adubação nitrogenada em Panicum maximum ocorreram quando existia um adequado suprimento de potássio. Também estudos realizados por Vicente-Chandler et al. (1962); França \& Haag (1985); Silva et al. (1995); Benetti \& Monteiro (1999) e Pereira 
(2001) verificaram efeito positivo na produção de matéria seca de Panicum maximum pelo fornecimento de potássio.

Por outro lado, Werner (1971), Corrêa (1991) e Lira et al. (1994) demonstraram o efeito positivo do fósforo na produção de matéria seca de gramíneas forrageiras. Desse modo, Hoffmann (1992) estudou a nutrição mineral e o crescimento do Panicum maximum cv. Colonião, determinando que a aplicação de doses crescentes de N, P, K, S promoveram aumentos na produção de massa seca. A produtividade máxima da parte aérea foi alcançada com a adição de 397, 202, 312 e 80 mg do nutriente em cada $\mathrm{kg}$ de solo, respectivamente, para $\mathrm{N}, \mathrm{P}, \mathrm{K}$ e $\mathrm{S}$, obtendo produção de 33,3 g MS (massa seca)/vaso, com primeiro corte realizado 46 dias após a emergência. Do mesmo modo, Faquin et al. (1994) estudaram as limitações nutricionais do capim Colonião e da Brachiaria decumbens, no noroeste do Paraná, pelo método de diagnose por subtração. Esses autores demonstraram redução da produção de MS da parte aérea das forrageiras em 75, 75, 70 e 60\%, respectivamente, para os tratamentos $-\mathrm{N},-\mathrm{P},-\mathrm{K}$ e -S. A produção do tratamento completo foi $44 \mathrm{~g}$ MS/vaso e os cortes, realizados 40 dias após a emergência e 30 dias após o primeiro corte. Também foi constatado efeito de concentração nos tratamentos que limitaram o crescimento. O perfilhamento das espécies foi afetado em ordem decrescente pelas omissões de P, N, S e K. Isto significa que, nesse solo, tanto o Colonião quanto a Braquiária somente terão crescimento e longevidade satisfatória se adubados $\operatorname{com} \mathrm{N}, \mathrm{P}, \mathrm{K}$ e S.

Monteiro et al. (1995), em um experimento com omissões dos macronutrientes em solução nutritiva com Brachiaria brizantha cv. Marandu, constataram redução de $45 \%, 70 \%$ e $30 \%$, respectivamente, na produção de massa seca da parte aérea, de raízes e no número de perfilhos quando compararam a omissão de magnésio, com o tratamento completo. Este apresentou produções de 14,3 e 5,9 g MS/vaso e 25 perfilhos/vaso, nas determinações apresentadas. Do mesmo modo, Corrêa (1996) observou efeito significativo do suprimento de magnésio (4,8 a $48 \mathrm{mg} / \mathrm{l})$ na produção de massa 
seca da parte aérea e raízes de três cultivares de Panicum maximum somente quando foi fornecida alta dose de nitrogênio, sendo esta de $378 \mathrm{mg} / \mathrm{l}$.

Por outro lado, segundo Faquin et al. (1994), os micronutrientes que mais comumente apresentam baixos teores no solo e deficientes nas culturas brasileiras são boro e zinco, e, mais raramente, o cobre. Em estudo realizado por Ferrari Neto et al. (1994), a omissão de boro, cobre e zinco na adubação de solo não promoveu queda de produção de massa seca e perfilhamento do capim Colonião, mesmo para boro, o qual se encontrava com teores baixos no solo (0,3 mg/dm ${ }^{3}$ em água quente). O autor evidencia que é de se esperar que, em sistemas de exploração intensiva, o boro possa aparecer em curto prazo, como limitação ao crescimento e à nutrição dessa forrageira.

\subsection{Diagnose química foliar}

A análise de nutrientes em material vegetal de determinado órgão e estádio fenológico tem sido utilizada para avaliar o estado nutricional das plantas, como também na determinação da prática de adubação. De acordo com o método clássico, a interpretação é feita comparando os resultados analíticos com parâmetros previamente estabelecidos (Malavolta, 1989). Essa análise se baseia na premissa de existir uma correlação positiva entre o suprimento de nutrientes e suas concentrações na planta e no fato de aumentos ou decréscimos nessas concentrações se relacionarem a maiores ou menores produções.

Em revisão realizada por Corsi \& Nussio (1994), concluiu-se que a interpretação dos resultados de análise de planta como método auxiliar para orientar recomendações de adubação deve merecer cuidados especiais quanto a espécie forrageira, estádio de desenvolvimento, parte da planta analisada, nível e potencial produtivo, época do ano, tipo e fertilidade do solo. Neste aspecto, segundo Mourão Filho (2000), a análise foliar pode ser uma 
ferramenta muito útil para a diagnose nutricional de plantas desde que procedimentos adequados estejam disponíveis para a análise dos dados. Em decorrência da natureza dinâmica da composição foliar, a qual é fortemente influenciada pela idade e maturação do tecido, bem como por todas as interações envolvendo absorção e translocação de nutrientes, a diagnose foliar pode tornar-se um processo de difícil entendimento e utilização prática.

Segundo Smith (1962), a parte da planta a ser amostrada é variável em função do nutriente, sendo as folhas geralmente mais recomendadas, pois a mistura de partes com diferentes idades fisiológicas determina perdas significativas da sensibilidade do diagnóstico. Devido ao fato de as folhas serem a sede da maioria dos processos fisiológicos, em geral, são analisadas (Raij et al., 1997). Por esta razão, Werner (1971) observou que as concentrações de nitrogênio nas folhas expandidas apresentavam maior correlação com a produção de matéria seca. Neste sentido, estudos realizados por Rossi (1999), Colozza (1998), Abreu (1999), Manarin (2000), Pereira (2001) e Lavres Júnior (2001) determinaram que as duas primeiras lâminas das folhas recémexpandias com lígula exposta são a parte da planta que mais representa o estado nutricional da forrageira.

No entanto, todos esses experimentos foram realizados em casa de vegetação, onde o efeito do manejo do pastejo não pode ser observado, pois existe uma padronização de freqüência e intensidade de corte, e os experimentos são de curta duração. Neste sentido, segundo Corsi \& Nussio (1994), pode-se explicar algumas das variações na composição mineral das plantas forrageiras por meio do metabolismo de cada nutriente na planta, e sua distribuição entre as partes do vegetal, e as inter-relações entre minerais, bem como destes com os fatores ambientais. Deste modo, torna-se questionável a validade de conclusões sobre a composição mineral da planta forrageira, principalmente quando submetida ao pastejo e quando se desconhecem informações complementares necessárias para auxiliarem na interpretação dos resultados, como idade da planta, nível de produtividade, época do ano, relação 
folha:haste, pressão de pastejo, consumo da planta forrageira e categoria do animal.

Em uma pastagem em crescimento vegetativo, na qual, aparentemente, apenas folhas são produzidas, a morfogênese pode ser descrita por três características básicas, sendo estas a taxa de surgimento de folhas (TSF), a taxa de alongamento foliar (TAF) e a duração de vida da folha (Chapman \& Lemaire, 1993). Estas características são determinadas geneticamente, mas são influenciadas por variáveis ambientais e por disponibilidade hídrica e de nutrientes. A combinação destas variáveis morfogênicas básicas determina as principais características estruturais das pastagens: tamanho das folhas, densidade de perfilhos e número de folhas por perfilhos (Nabinger, 1999).

O manejo do pastejo tem grande impacto sobre a maioria dos processos envolvidos em sistemas baseados no uso de pastagens, influenciando o crescimento e a morfologia das planta (Da Silva \& Pedreira, 1997). Segundo Gonçalves (2002), o padrão de desfolha também exerce efeito sobre a taxa de surgimento de folhas, principalmente quando relacionado às alterações na altura do relvado e à oferta de forragem. Parsons et al. (1991) demonstraram que folhas de azevém perene aparecem mais lentamente em relvados mantidos mais altos, demorando mais para completar sua expansão. Segundo Hodgson et al. (1981), incrementos na intensidade de desfolha de uma pastagem resultam em redução do comprimento do colmo mais bainha. Deste modo, segundo Skinner \& Nelson (1995), o maior comprimento da bainha conduz a planta a uma menor taxa de surgimento de folhas. Esse comportamento se deve à modificação do tempo gasto pela folha, desde sua iniciação no meristema até seu aparecimento acima do colmo mais bainha, formado pelas folhas mais velhas (Garcez Neto et al., 2002).

Neste sentido, Barbosa et al. (2002) observaram que a taxa de surgimento de folhas no resíduo alto foi inferior à verificada em resíduo baixo, quando estudaram as características morfogênicas de capim Tanzânia durante os 35 dias de rebrota, em dois resíduos pós-pastejo, sendo estes de 3,6 e 2,3 t 
de MS/ha, denominados resíduo alto e baixo, respectivamente. A adubação foi realizada após a saída dos animais do piquete com $100 \mathrm{~kg}$ de nitrogênio/ha, sendo as avaliações realizadas no mês de novembro. O número de folhas vivas por perfilhos é o produto entre o tempo de vida da folha e sua taxa de surgimento, sendo o número máximo de folhas vivas por haste uma constante genotípica (Davies, 1988). Deste modo, alterações na taxa de surgimento de folhas podem influenciar o seu tempo de vida.

Garcez Neto et al. (2002) estudaram as respostas morfogênicas de capim Mombaça sob diferentes alturas de corte $(5,10$ e $20 \mathrm{~cm}$ ) em casa de vegetação. Mostraram que a duração de vida da folha foi aumentada com a altura de corte, sendo 32, 38 e 45 dias para 5, 10 e $20 \mathrm{~cm}$, respectivamente. Além disso, foi observado que o aumento do comprimento da bainha por meio de diferentes cortes aumentou o comprimento da lâmina foliar, estabelecendo correlação entre comprimento da bainha e comprimento da lâmina, determinando que a altura de pastejo é um importante fator na definição do tamanho final da lâmina.

Deste modo, em ambiente que impõe diferenças de manejo a partir da intensidade promovida pelo pastejo ou corte, as características morfológicas e estruturais do dossel forrageiro podem ser alteradas. Lâminas foliares ocupando a mesma posição no perfilho podem apresentar diferenças em tamanho e duração de vida. Neste sentido, segundo Raij (1991) e Malavolta et al. (1997), a idade do tecido vegetal influencia a concentração dos nutrientes nesse tecido. Deste modo, os nutrientes como nitrogênio, fósforo, potássio, magnésio, cloro e molibdênio são móveis na planta, determinando que folhas mais jovens apresentam concentrações mais elevadas que folhas velhas. Por outro lado, em elementos como cálcio, enxofre, zinco, cobre, manganês, ferro e boro, freqüentemente, há um aumento relativo da concentração com o envelhecimento do tecido vegetal.

Sendo assim, alterações na duração de vida da folha, causadas por alterações de manejo, podem interferir nas correlações entre a concentração de 
nutrientes em partes da planta e a produção de massa seca da forragem em estudos que determinam a parte da planta a ser amostrada para diagnose foliar.

Os principais critérios para interpretar a análise química foliar são nível crítico, faixa de suficiência e Sistema Integrado de Diagnose e Recomendação (DRIS), segundo Reis Júnior (1999).

\subsubsection{Nível crítico}

Segundo Summer (1979), nível crítico é a concentração em uma parte específica da planta, em determinado estádio de crescimento correspondente a um percentual da produção máxima, mais especificamente, a 90 - $95 \%$ deste máximo. Procura-se, deste modo, comparar a concentração do nutriente em determinado órgão da planta a um banco de dados de referência.

Neste sentido, a concentração de nitrogênio nas folhas novas aos 28 dias de crescimento, determinada por Abreu (1999) como correspondente a 90\% da produção máxima, foi, para o capim Marandu, 23,2 g/kg MS, e para capim Tanzânia, 21,4 g/kg MS. Do mesmo modo, Hoffman et al. (1995) determinaram os níveis críticos de nitrogênio em capim Colonião aos 46 dias de crescimento após a emergência, obtendo valores de 11,4 e 13,8 g/kg MS na parte aérea e 15,7 e 19,4 g/kg de nitrogênio nas folhas totalmente expandidas, respectivamente, para 80 e 90\% da produção máxima, sendo esta de $34,5 \mathrm{~g}$ MS/vaso.

Colozza (1998) determinou os níveis críticos de nitrogênio para 90\% da produção máxima nas duas primeiras lâminas de folhas totalmente expandidas, com lígula visível. Para capim Aruana (Panicum maximum), foram 18,8 e 21,6 $\mathrm{g} / \mathrm{kg} \mathrm{MS}$, e, para o capim Mombaça, 20,8 e 22,9 $\mathrm{g} / \mathrm{kg}$ MS no primeiro e no segundo corte, respectivamente, sendo estes realizados aos 34 e 28 dias após a emergência e 34 e 35 dias após o primeiro corte, respectivamente para Aruana e Mombaça. As produções máximas encontradas para o capim 
Mombaça foram 18 e $37 \mathrm{~g}$ MS/vaso, respectivamente para o primeiro e o segundo corte.

Por outro lado, Dias Filho (1995) encontrou para Panicum maximum cv. Tanzânia, Colonião e Tobiatã respectivamente, níveis críticos internos na parte aérea para fósforo de 2,0, 2,1 e 2,2 g/kg MS, referentes a 90\% da produção máxima em plantas com 35 dias de crescimento. As produções máximas foram próximas a $30 \mathrm{~g} \mathrm{MS/vaso} \mathrm{para} \mathrm{os} \mathrm{três} \mathrm{cultivares.} \mathrm{Do} \mathrm{mesmo}$ modo, Corrêa et al. (1996) determinaram que o nível crítico interno de fósforo na parte aérea de capim Tanzânia, Mombaça, Vencedor e T21 foi 2,3 g/kg MS para $80 \%$ da produção máxima, correspondente a $2.050 \mathrm{~kg} \mathrm{MS} / \mathrm{ha}$, aos 85 dias após o plantio.

Rossi (1999) estudou a nutrição em fósforo em capim Colonião, utilizando doses crescentes ( 0,31 a $46,5 \mathrm{mg} / \mathrm{l})$ em solução nutritiva, obtendo, para todas as partes da planta estudadas, aumento linear na concentração de fósforo com essas doses. Os níveis críticos internos determinados para as partes da planta foram 1,3 g/kg MS para raiz, 2,3 g/kg MS para as folhas nãoexpandidas, 1,6 $\mathrm{g} / \mathrm{kg}$ MS para lâminas de folhas novas, $1,5 \mathrm{~g} / \mathrm{kg}$ MS para as lâminas de folhas velhas e de 1,8 g/kg MS para colmo mais bainha, no primeiro corte, realizado 40 dias após o transplante das mudas para os vasos. Por outro lado, Martinez (1980) avaliou a eficiência de absorção e utilização de fósforo por algumas gramíneas forrageiras em solução nutritiva, determinando que o nível crítico interno de fósforo associado ao máximo crescimento de Colonião foi 2,3 g/kg MS em plantas com 75 dias de desenvolvimento. Nesse estudo, as concentrações de fósforo nas folhas e na raiz foram de 2,9 e 1,1 g/kg MS, respectivamente.

Pereira (2001) estudou o efeito de potássio e magnésio em solução nutritiva em capim Mombaça na concentração destes nutrientes em diferentes partes da planta. A concentração aumentou significativamente em todas partes da planta com o incremento de potássio na solução nutritiva. As maiores e menores concentrações ocorreram nos colmos mais bainhas $(39,2$ e 31,8 g/kg 
MS no primeiro e no segundo corte, respectivamente) e nas lâminas de folhas maduras (26,9 e 27,8 g/kg MS nos respectivos primeiro e segundo cortes). Para o magnésio, a concentração em todas as partes analisadas aumentou significativamente com o incremento do nutriente na solução nutritiva até a dose máxima estudada (60 mg/l). As maiores e menores concentrações ocorreram nos colmos mais bainhas (7,0 e 5,6 $\mathrm{g} / \mathrm{kg}$ MS no primeiro e no segundo corte, respectivamente) e nas lâminas das folhas emergentes (3,9 e 1,9 g/kg MS, respectivamente para o primeiro e o segundo corte). Os cortes foram realizados 30 e 29 dias após o transplante e 22 e 21 dias após o primeiro corte, respectivamente para os experimentos com potássio e magnésio. As produções máximas obtidas nesses experimentos foram 20 e $35 \mathrm{~g}$ MS/vaso para potássio e 14 e $28 \mathrm{~g} \mathrm{MS/vaso} \mathrm{para} \mathrm{magnésio,} \mathrm{nos} \mathrm{respectivos} \mathrm{primeiro} \mathrm{e} \mathrm{segundo}$ cortes. Observam-se as variações nas concentrações dos nutrientes em estudo em diferentes partes da planta, ressaltando a importância da determinação e padronização da parte a ser amostrada para diagnose para que os resultados possam ser comparados. Nesse experimento, as lâminas de folhas recémexpandidas foram consideradas adequadas para a avaliação do estado nutricional, apresentando valores de nível crítico de 15,4 e 17,3 g/kg para K, respectivamente para o primeiro e o segundo corte, e 4,2 g/kg para $\mathrm{Mg}$. Skerman \& Riveros (1992) avaliaram a concentração de magnésio na matéria seca de 280 gramíneas forrageiras e verificaram uma variação de 0,4 a 9,0 g/kg MS, obtendo uma média de 3,6 g/kg MS.

Por outro lado, Andrade et al. (2000), trabalhando com capim Elefante cv. Napier, sob doses de nitrogênio e potássio, determinaram que os níveis críticos de potássio nas lâminas foliares e colmos foram 20,0 e 21,3 g/kg MS, respectivamente. As plantas foram cortadas com 54 dias de desenvolvimento e produção máxima próxima a $5.000 \mathrm{~kg} / \mathrm{ha}$, nas maiores doses de nitrogênio e potássio.

Coutinho et al. (2001) determinaram os níveis críticos para nitrogênio e potássio em Cynodon dactylon cv. Coastcross irrigado, manejado entre julho de 
1996 e setembro de 1997, com freqüência de cortes de 35 dias no período de primavera e verão e de 45 dias no período de outono e inverno. Os níveis críticos para $90 \%$ da produção máxima $(5.000 \mathrm{~kg} / \mathrm{ha})$ na parte aérea da planta foram 24,0 e 14,0 g/kg MS, respectivamente para nitrogênio e potássio. Nesse experimento, devido ao fato de as concentrações dos nutrientes terem sido determinadas na planta toda, a comparação com os resultados já apresentados fica prejudicada. Observa-se que o nível crítico determinado para potássio está abaixo dos valores apresentados até o presente momento, o que pode ser uma característica da espécie em estudo ou da metodologia de amostragem.

Faquin et al. (1994) determinaram em seu tratamento completo (adubado com 300 mg N, 200 mg P, 150 mg K, 75 mg Ca, 15 mg Mg, 50 mg S, 0,5 mg B, 1,5 mg Cu e $5 \mathrm{mg}$ Zn por $\mathrm{kg}$ de solo), com produção de $44 \mathrm{~g}$ MS/vaso e corte realizado 40 dias após a emergência, que a concentração na parte aérea de capim Colonião foi 18 para N, 5 para $\mathrm{P}, 10$ para K, 5 para Ca, 3 para Mg, 2 para $\mathrm{S}$ em g/kg MS, e 23 para B, 8 para $\mathrm{Cu}, 79$ para Fe, 424 para Mn e 50 para $\mathrm{Zn}$ em $\mathrm{mg} / \mathrm{kg}$ MS.

\subsubsection{Faixa de suficiência}

A utilização das faixas de suficiência para interpretação da diagnose química foliar está menos sujeita aos pequenos efeitos de ambiente e da planta em comparação ao nível crítico. No entanto, este método diminui a precisão do diagnóstico, pois os limites são mais amplos.

As faixas de suficiência para capim Colonião na parte aérea e no primeiro corte, realizado 46 dias após a emergência, correspondentes a 80 e $90 \%$ da produção máxima, foram, respectivamente: 11,4 e 13,8 para N; 1,6 e 2,4 para o P; 0,9 e 1,1 para $S$ em $\mathrm{g} / \mathrm{kg}$ MS. Da mesma maneira, nas folhas novas, esses valores foram 15,7 e 19,4 para N, 1,5 e 2,4 para $P$, e 0,8 e 1,0 para S em g/kg MS, respectivamente (Hoffmann, 1992). 
Segundo Malavolta et al. (1997), as concentrações de macronutrientes consideradas adequadas para capim Colonião são: 11,3 a 15,0 para N; 0,8 a 1,1 para $\mathrm{P} ; 14,3$ a 18,4 para K; 4,0 a 10,2 para Ca; 1,2 a 2,2 para Mg e 1,1 a 1,5 para $S$ em g/kg MS. Para os micronutrientes, são 15 a 20 para $B, 7$ a 10 para $\mathrm{Cu}, 100$ a 150 para Fe, 80 a 100 para Mn e 20 a 25 para Zn em mg/kg MS. Do mesmo modo, Werner et al. (1997) demonstraram a faixa de suficiência para capim Colonião como sendo 15 a 25 para N, 1,0 a 3,0 para P, 15 a 30 para K, 3 a 8 para $\mathrm{Ca}, 1,5$ a 5,0 para Mg e 1,0 a 3,0 para $\mathrm{S}$ em g/kg MS, e 10 a 30 para B, 4 a 14 para $\mathrm{Cu}, 50$ a 200 para Fe, 40 a 200 para Mn e 20 a 50 para Zn em $\mathrm{mg} / \mathrm{kg} \mathrm{MS}$.

\subsubsection{DRIS}

O correto diagnóstico dos fatores nutricionais que limitam a produtividade das forrageiras pode levar a um manejo mais adequado, promovendo importante redução nos custos da exploração pecuária, à medida que possibilita maior eficácia da intervenção a ser feita sobre o sistema. Contudo, o diagnóstico do estado nutricional das forrageiras nem sempre conduz a resultados confiáveis.

Os métodos usuais para a interpretação de análise química de tecido vegetal pressupõem a comparação das concentrações de nutrientes encontradas a valores de referência. Concentrações de nutrientes abaixo ou acima dos valores de referência são associadas a decréscimo no crescimento vegetativo. Esses métodos procuram avaliar valores isolados de deficiência ou excesso, sem mensurar o balanço nutricional.

Uma nova forma de interpretação dos resultados de análise foliar foi desenvolvida e proposta primeiramente por Beaufils (1957; 1971; 1973), em seringueira, denominando-se sistema integrado de diagnose e recomendação (DRIS - Diagnosis and Recommendation Integrated System). O método DRIS 
utiliza relações entre nutrientes, em vez de concentração absoluta e isolada, para interpretar a análise de tecido vegetal (Mourão Filho, 2000).

O sistema integrado de diagnose e recomendação, originalmente, foi desenvolvido com propósitos amplos, visando a diagnosticar as causas primárias e secundárias que afetam a produtividade das culturas. Entretanto, segundo Bataglia \& Santos (1990), atualmente, o DRIS se tem popularizado como critério de avaliação do estado nutricional das plantas.

O DRIS baseia-se no cálculo de um índice para cada nutriente, comparando as relações entre um nutriente e cada um dos demais nutrientes na amostra sob diagnose, com as relações envolvendo esse mesmo nutriente em uma população de alta produtividade (população de referência).

Os índices são expressos por valores positivos, negativos ou nulos. Valores positivos indicam excesso do nutriente em estudo em relação aos demais; valores negativos significam deficiência e, quanto mais próximos de zero estiverem esses índices, maior o equilíbrio nutricional da planta (Walworth \& Sumner, 1987). Segundo Jones (1981), Walworth \& Sumner (1987) e Mourão Filho (2000), a base do DRIS é formada pelas seguintes premissas: 1) as relações entre os nutrientes são, freqüentemente, melhores indicadores de deficiência nutricional do que valores isolados de concentração de nutrientes; 2) algumas relações entre nutrientes são mais significativas que outras; 3) somente quando relações nutricionais importantes são observadas próximas aos valores ideais ou ótimos, as produtividades máximas são atingidas; 4) a variância de uma relação nutricional importante é menor em uma população de alta produtividade (população de referência) do que em populações de baixa produtividade; 5) o valor ideal do índice DRIS para cada nutriente deve ser zero.

Desse modo, Baldock \& Schulte (1996) concluíram que o método DRIS apresenta quatro vantagens: a escala é contínua e facilmente interpretada; o DRIS classifica os nutrientes desde o mais deficiente ao mais excessivo; o DRIS pode identificar alguns casos em que a produtividade é limitada por desbalanço de nutrientes, mesmo que nenhum deles esteja abaixo de seu nível 
crítico; e o IBN (Índice de Balanço Nutricional) pode medir o efeito conjunto dos nutrientes sobre a produtividade. Por outro lado, estes autores também apontaram quatro desvantagens: é um sistema que exige computação um pouco complexa; os índices não são independentes, ou seja, o nível de um nutriente pode ter efeito sobre os outros nutrientes; resulta em diagnoses positivas falsas com muita freqüência; e, embora tenha sido divulgado que este sistema é menos sensível à maturidade da planta, na prática, é freqüentemente tão sensível quanto o método de faixa de suficiência.

Inicialmente, para a implantação do DRIS é preciso estabelecer valorespadrão. Os padrões nutricionais do DRIS são denominados normas, extraídas de uma população de alta produtividade, conhecida como população de referência. Segundo Nick (1998), a seleção dessa população tem grande importância para o sucesso do DRIS. Do mesmo modo, de acordo com Walworth \& Sumner (1987), um dos principais passos na formação do método DRIS é a definição dos valores de referência. Neste sentido, Leite (1992) utilizou 24 observações para dar origem às normas DRIS específicas para Coffea canephora cv. Conilon, cultivado ao norte do Estado do Espírito Santo. Do mesmo modo, Walworth et al. (1988) desenvolveram normas DRIS para milho a partir de dez observações, com produtividade maior que $18 \mathrm{t}$ MS/ha. Comparando o número de observações realizadas por Leite (1992) e Walworth et al. (1988) com as 2.800 utilizadas por Sumner (1977), para determinação das normas DRIS para milho, na África do Sul, questiona-se o tamanho ideal da população para dar origem a confiáveis normas DRIS. Deste modo, se, por um lado, as normas estabelecidas por Leite (1992) e Walworth et al. (1988) são mais específicas, e possibilitaram bom resultados em cultivares e regiões restritas, por outro, as observações realizadas por Sumner (1977), devido a sua abrangência, são mais genéricas, referindo-se a todos os cultivares de milho e a todo o território da África do Sul.

Neste aspecto, segundo Mourão Filho (2000), populações específicas, com pequeno número de observações, padronizadas quanto ao porta-enxerto e 
referentes a um ou dois anos de amostragem foliar e produção, formam bancos de dados mais eficientes para a obtenção das normas DRIS.

Creste \& Grassi Filho (1998) estabeleceram curvas de produtividade para três cultivares de laranja doce sobre dois porta-enxertos na região sudoeste do Estado de São Paulo. Os autores ressaltaram que normas regionais para DRIS devem ser estabelecidas, em vez de normas gerais e universais.

O uso universal das normas DRIS tem sido questionado (Hallmark \& Beverly, 1991), pois diferenças entre normas geradas a partir de populações e locais distintos têm sido encontradas (Bataglia \& Santos, 1990), demonstrando que não são inteiramente independentes de condições locais e época de amostragem (Reis Júnior, 1999).

Neste sentido, Beaufils (1973) relatou que a utilização do índice podem ser melhorada a partir do aumento considerável do número de observações da população de referência ou de sua particularização. No mesmo sentido, Bataglia \& Santos (1990), estudando o efeito do procedimento de cálculo e da população de referência nos índices DRIS em seringueiras, concluíram que existem evidências da necessidade de particularização da população de referência.

Segundo Nick (1998), a qualidade, mais que a quantidade de observações, deve ser a característica mais importante de uma base de dados que forme a população de referência.

A população inicial deve ser subdividida em duas categorias: população de referência (normas); e população de não-referência. Diversas pesquisas têm revelado que a seleção da população de referência é um importante fator no sucesso e eficiência do DRIS. Segundo Walworth \& Sumner (1987), o ponto de referência para separar as duas subpopulações deve ser escolhido de forma arbitrária. Por outro lado, Malavolta et al. (1997) recomendam que o ponto de referência seja $80 \%$ da produção máxima.

Sendo assim, Mourão Filho (2000) concluiu que os critérios para a definição da subpopulação de referência precisam ser estudados e, de certa 
forma, ajustados especificamente, para cada situação. Deste modo, normas DRIS devem ser desenvolvidas para condições específicas, em que todos os demais fatores que se correlacionem com produtividade sejam conhecidos e isolados.

Após a escolha da população de referência e determinação das normas, a razão entre um par de nutrientes deve ser definida, podendo ser tanto direta quanto inversa ( $X / Y$ ou $Y / X$, onde $X$ e $Y$ são concentrações de nutrientes). Nos cálculos do método DRIS, apenas um tipo de expressão é utilizado para relacionar cada par de nutrientes. Neste sentido, a ordem pode ser direta ou inversa para todos os nutrientes (Beaufils, 1973), definida pela razão das variâncias da população de referência e população de não-referência (Letzsch, 1985); ou definida por meio do cálculo dos coeficientes de correlação (r) entre os valores da variável-resposta da planta (produtividade) e a razão entre os pares de nutrientes (Nick, 1998).

Assim, Bataglia \& Santos (1990) testaram a utilização da razão dos nutrientes nas formas direta e inversa, demonstrando que apenas os índices dos nutrientes calculados pelo método proposto por Jones (1981) foram sensíveis a mudanças na ordem da razão. Nick (1998), estudando o DRIS para cafeeiros podados, demonstrou que as normas DRIS definidas por meio do critério por ele proposto (cálculo dos coeficientes de correlação) foram mais precisas que aquelas determinadas pelo critério de Letzsch (1985), desde que seguidas pelo método de Jones (1981) para cálculo das funções das razões dos nutrientes. Desse modo, observa-se que a ordem da razão a ser utilizada parece estar na dependência do método escolhido para o cálculo das funções, sendo o método proposto por Jones (1981) mais sensível a essas modificações.

As funções das razões dos nutrientes podem ser calculadas a partir de diferentes métodos, e, apesar de estes terem sido avaliados em alguns trabalhos, o mais recomendado ainda não foi definido. O método proposto originalmente por Beaufils (1973) para cálculo dos índices utiliza relações percentuais para estabelecer as funções dos nutrientes e impõe restrições 
quando a relação na amostra é maior ou menor que a relação média da população de referência. As diversas funções são ponderadas por meio da recíproca dos coeficientes de variação (C.V.) das respectivas relações da população de referência. Neste sentido, Elwali \& Gascho (1984) propuseram uma modificação no cálculo dos índices, considerando dois nutrientes balanceados se a razão de suas concentrações em uma amostra estiver dentro da faixa dada pela média geral da relação na população de referência mais ou menos seu desvio-padrão, sendo os procedimentos para os cálculos os mesmos propostos por Beaufils (1973). Por outro lado, Jones (1981) propôs uma simplificação do método de Beaufils (1973). Esse método não considera se o valor da relação na amostra é maior ou menor que a da população de referência e pondera a variabilidade das relações por meio da recíproca do desvio-padrão.

Finalmente, para o cálculo dos índices DRIS, é realizada a somatória em módulo das funções envolvendo cada nutriente (Beaufils, 1973).

O DRIS tem sido aplicado em várias culturas, como cana-de-açúcar (Reis Júnior, 1999), laranja (Beverly et al., 1984; Veloso et al., 2000; Mourão Filho et al., 2002), limão (Creste \& Nakagawas, 1997), café (Nick, 1998; Reis Júnior et al., 2002; Silva et al., 2003), abacaxi (Angeles et al., 1990), uva (Bhargava et al., 1996), eucalipto (Wadt et al., 1999), soja (Beverly, 1987; Beverly, 1993b; Hallmark et al., 1994), milho (Summer, 1977; Walworth et al., 1988; Beverly, 1993a) e sorgo (Sumner, 1983).

Poucas pesquisas foram realizadas com forrageiras, podendo ser citadas as normas desenvolvidas por Walworth et al. (1986), com alfafa (Medicago sativa L.); Bailey et al. (1997a), Bailey et al. (1997b) e Bailey et al. (2000), com Azevém perene; Tarpley et al. (1985), com Bermuda grass cv. Coastal (Cynodon dactylon sp.); e Silveira et al. (2003), com Brachiaria decumbens. Deste modo, estudos e normas DRIS em gramíneas tropicais ainda são incipientes, demonstrando a importância da realização deste estudo com capim Tanzânia (Panicum maximum). 


\subsection{Fatores que influenciam a nutrição}

Segundo Munson \& Nelson (1973), os fatores diretamente responsáveis por alterações na concentração dos nutrientes no tecido vegetal são espécie e/ou variedade, condições do ambiente, tipo de tecido e idade, forma química do nutriente considerado, níveis de nutrientes e suas interações. Sendo assim, o conteúdo de minerais na planta depende de vários fatores, incluindo espécie forrageira, estádio e maturidade da planta, produção e manejo das forragens, estação do ano, tipo e fertilidade dos solos e condições climáticas (Cecato et al., 2001). Observa-se que existem inúmeros fatores que influenciam a nutrição das plantas forrageiras, dentre os quais se podem destacar os fatores climáticos, solo, sistema radicular, adubação, intensidade de pastejo, manejo da pastagem, sendo estes os mais enfatizados, pois estão mais relacionados aos objetivos deste trabalho.

\subsubsection{Fatores climáticos}

Observa-se que há uma relação direta entre precipitação pluvial, energia radiante e temperatura na modulação da matéria seca. O período de menor formação de biomassa ocorre de julho a setembro, meses em que, dependendo do estresse hídrico, pode ocorrer intensa deficiência de N, associada, às vezes, a carência de $\mathrm{Ca}, \mathrm{Mg}$ e B. Uma precipitação pluvial excessiva sobre solos que não sejam arenosos pode acarretar o fenômeno da anaerobiose, ausência de oxigênio, induzindo a desnitrificação. Por outro lado, secas prolongadas podem induzir a deficiências minerais pela diminuição da mineralização da matéria orgânica do solo pelos microorganismos (Haag \& Dechen, 1994). 
Armeli et al. (2001) realizaram estudo comparativo entre as concentrações de cálcio, potássio, magnésio, manganês e sódio, em três gramíneas forrageiras, em diferentes tipos de solo e duas épocas do ano: 03/02/1998 (chuvas) e 04/08/1998 (seca). Com relação à época de corte, o período seco foi o que proporcionou, em média, as maiores concentrações de cálcio e magnésio, sendo 2,5 e 2,2 g/kg MS e 5,5 e 3, g/kg MS para cálcio e magnésio, respectivamente, nos períodos das chuvas e da seca. Esse fato foi relacionado pelo autor ao efeito de concentração, devido ao menor desenvolvimento e acúmulo de massa seca de forragem no período seco. Já para potássio, as maiores concentrações ocorreram no período das chuvas (14,08 g/kg MS), em relação às do período de seca (11,08 g/kg MS). Segundo o autor, a redução da concentração de potássio na forragem colhida no período seco pode ser resultado de efeito antagônico entre cátions, provocado pelo aumento da concentração de Ca.

Deste modo, a composição mineral da forragem ao longo do ano em pastagens irrigadas deve ser diferente quando comparada à de pastagens nãoirrigadas. A suplementação de água (irrigação) pode alterar a composição mineral dessas plantas em dois momentos, durante períodos de veranicos e, principalmente, durante o inverno. Além disso, o florescimento dessas plantas pode ser responsivo a um hidroperíodo, podendo ocorrer alterações na fisiologia do florescimento devido à irrigação. Por este motivo, pastagens irrigadas podem apresentar diferenças na qualidade ao longo do ano, quando comparadas às de sequeiro (Balsalobre, 2002).

\subsubsection{Fatores físicos do solo}

Dentre os fatores físicos, possivelmente o que mais afeta 0 desenvolvimento das forrageiras seja a compactação, podendo ser genética, natural do solo ou causada pelo manejo inadequado do pasto. Assim, o 
pastoreio intensivo ocasiona redução da infiltração de água e/ou aumento da densidade do solo. Havendo redução do sistema radicular e sendo o solo de baixa fertilidade, certamente, devem ocorrer distúrbios nutricionais na planta, especialmente deficiência de N, P e S (Haag \& Dechen, 1994). Por outro lado, Da Silva et al. (1999) avaliaram o grau de compactação a partir de dados de resistência à penetração, em pastagens sob sistema de manejo rotacionado e extensivo. Os autores concluíram que o solo sob manejo rotacionado apresentava grau de compactação inferior àquele observado em manejo extensivo.

Assim, Da Silva et al. (2003) trabalharam em pastagens de capim Tanzânia, manejado em três resíduos pós-pastejo (1.000, 2.500 e 4.000 kg MSV (massa seca verde)/ha) e determinaram o efeito do nível de pisoteio na resistência do solo à penetração para o tratamento de alta intensidade de pastejo (1.000 kg MSV/ha). Segundo o autor, considerando os valores de índice de cone (IC) após a correção da umidade com equações múltiplas, a elevação da taxa de lotação de 3,6 para 4,8 UA/ha (unidade animal por hectare) não alterou significativamente o IC, que passou de 6,13 para 6,20 MPa (mega pascal), respectivamente para os tratamentos de baixa (4.000 kg MSV/ha) e média $(2.500 \mathrm{~kg} / \mathrm{ha})$ intensidade de pastejo. Por outro lado, quando a taxa de lotação passou de 4,8 para 5,7 UA/ha, tratamentos de média e alta intensidade, respectivamente, ocorreu um aumento significativo no IC, passando de 6,2 para 9,92 MPa.

A elevação brusca do índice de cone a partir de determinadas taxas de lotação animal pode ser atribuída à compactação adicional do solo. Ela ocorre quando a pressão aplicada sobre o solo é maior que a pressão de préconsolidação, definida como a maior pressão que o solo já suportou no passado (Dias Júnior \& Pierce, 1996). A pressão de pré-consolidação é, portanto, o limite de pressão que o solo suporta antes que a compactação adicional ocorra e reflete o manejo utilizado. O entendimento da compactação adicional do solo é importante, pois pode causar redução da absorção de nutrientes pelas plantas, 
decréscimo da infiltração, e redistribuição de água e das trocas gasosas, aumentando a resistência mecânica dos solos e restringindo o crescimento radicular com conseqüente redução da produtividade e aumento da erosão hídrica (Smucker \& Erickson, 1989; Bicki \& Siemens, 1991; Lafond et al., 1996, citados por Da Silva et al., 2003).

Da Silva et al. (2004) realizaram um trabalho com capim Tanzânia, com e sem o uso de irrigação, com 5,9 e 5,6 UA/ha respectivamente, manejado com $2.500 \mathrm{~kg}$ de MSV por hectare de resíduo pós-pastejo. Observou-se que 33 dias de descanso da pastagem foram suficientes para reduzir significativamente o IC corrigido, de 13,05 para $9,75(-25 \%)$ no tratamento irrigado e de 23,75 para $16,11 \mathrm{MPa}(-32 \%)$ no não-irrigado. Portanto, 33 dias de pousio da pastagem foram suficientes para recuperação física do solo.

Valores de resistência do solo à penetração superiores a $2 \mathrm{MPa}$ indicam situação de comprometimento da qualidade física do solo para crescimento de plantas, caracterizando a compactação do solo (Da Silva et al., 1999). No entanto, foi verificado que os valores de IC medidos com penetrômetro manual de campo tenderam a ser superestimados, sendo estes muito acima dos valores críticos admitidos pela literatura como restritivos ao crescimento radicular. Deste modo, segundo o autor, a explicação para os altos valores de IC observados reside no fato de o penetrômetro manual registrar a resistência máxima do solo à penetração. Foi verificado, por meio do penetrômetro eletrônico de laboratório, que constrói uma figura registrando todos os valores de IC ponto a ponto durante o deslocamento da agulha ao penetrar na amostra, que a resistência máxima se concentra nos primeiros centímetros de solo, atingindo o pico em uma região estreita, decrescendo bruscamente em seguida. O mesmo aparelho calcula a média do IC dividindo a soma dos valores lidos ponto a ponto pelo número de pontos de deslocamento ao longo da amostra. A média apresentou-se significativamente menor que os valores máximos encontrados na maioria das amostras, indicando que a compactação do solo na 
área em questão se concentra em uma camada superficial estreita, justamente aquela atingida pelo aparelho manual de campo (Da Silva et al., 2004).

Deste modo, estima-se que um bovino de $400 \mathrm{~kg}$ transmita ao solo pressões de aproximadamente $0,35 \mathrm{MPa}$ ou $3,5 \mathrm{~kg} \mathrm{~cm}^{2}$. A pressão de pisoteio das patas dos animais aplica altas cargas no solo, ocasionando a compactação em profundidades que variam de 7 a $10 \mathrm{~cm}$ (Peterson, 1970). Resultados semelhantes foram observados por Davies et al. (1989) em experimento conduzido em pastagem utilizada com gado leiteiro por 26 anos, na qual verificaram que a densidade do solo aumentou rapidamente até a profundidade de 10-12 cm, diminuindo a profundidades maiores. Carvalho (1976) avaliou atributos físicos do solo em pastagem com quatro anos de uso a partir do monitoramento da densidade do solo, porosidade total e distribuição de poros por tamanho, e os resultados demonstraram que a compactação foi observada até a profundidade de $7,5 \mathrm{~cm}$.

Assim, o estudo sobre a relação entre compactação do solo e intensidade de manejo se apresenta necessário para definir seus efeitos sobre a nutrição por meio das concentrações dos nutrientes em diferentes partes da planta.

\subsubsection{Sistema radicular}

O efeito da área de superfície absorvente de raízes ocorre devido à difusão, principal mecanismo responsável pela movimentação do fósforo até a superfície do sistema radicular, onde é absorvido. O movimento provocado pela difusão dos minerais como $\mathrm{P}$ e K pode ser representado pela equação indicada por Malavolta et al. (1997):

$\mathrm{Dq} / \mathrm{dt}=\mathrm{DAP}(\mathrm{C} 1-\mathrm{C} 2) / \mathrm{L}$,

onde: 
$\mathrm{Dq} / \mathrm{dt}=$ quantidade de elemento que se difunde até as raízes;

$D=$ coeficiente de difusão do nutriente na água;

$\mathrm{A}=$ área total de absorção (sistema radicular);

$\mathrm{P}=$ parte do volume do solo ocupada pela água;

$\mathrm{C} 1$ = concentração do nutriente solúvel à distância $L$ da superfície da raiz; e

C2 = concentração do nutriente solúvel ao nível da raiz.

Deste modo, qualquer fator que interfira no volume do sistema radicular afeta diretamente a quantidade de fósforo absorvida. Assim, pastejos freqüentes e severos, e camadas de impedimento ao crescimento radicular (compactação, encharcamento, presença de barreiras químicas) devem concorrer para que a exigência externa da planta em fósforo seja aumentada (Corsi \& Nussio, 1994).

Por outro lado, Thornton \& Milard (1993) verificaram que um incremento na severidade de desfolha resultou em decréscimo da massa radicular, associado à diminuição da absorção de nitrogênio, de 0,54 para 0,14 $\mathrm{mg} / \mathrm{semana/planta} \mathrm{em} \mathrm{azevém} \mathrm{perene} \mathrm{quando} \mathrm{a} \mathrm{planta} \mathrm{foi} \mathrm{repetidamente}$ cortada a 8 e $4 \mathrm{~cm}$, respectivamente.

Além disso, a recuperação do sistema radicular pode ser influenciada pela intensidade de pastejo. Pagoto (2001) determinou, em capim Tanzânia irrigado, no tratamento de alta intensidade, caracterizado por apresentar massa de forragem pós-pastejo igual a $1.000 \mathrm{~kg}$ de MSV/ha, que o sistema radicular demorava 21 dias para retomar seu crescimento após o pastejo, enquanto os tratamentos de média (2.500 kg de MSV/ha) e baixa intensidade (4.000 kg de MSV/ha) retomavam esse crescimento em 12 dias.

Assim, o pastejo intensivo em áreas irrigadas pode provocar adensamento no solo, condições temporárias de anaerobiose e redução do sistema radicular conforme o grau de intensificação. Estas condições podem afetar a absorção de nutrientes pela planta forrageira. 


\subsubsection{Relação entre os nutrientes}

\subsubsection{Potássio, magnésio e cálcio}

A interação do magnésio e do potássio pode ocorrer em culturas que requerem altas quantidades de potássio para uma elevada produção e boa qualidade (Raij, 1991). Essa interação é denominada antagonismo, pois um íon interfere negativamente na absorção do outro. Neste sentido, Soares (1978) demonstrou que o aumento da quantidade absorvida de um cátion na planta, de maneira geral, reduz a quantidade de um ou mais cátions. Assim, tanto o potássio pode reduzir a absorção de cálcio e/ou magnésio, como estes podem diminuir a absorção de potássio. Do mesmo modo, segundo Marschner (1986), cátions como potássio e cálcio competem efetivamente com o magnésio e diminuem grandemente sua absorção quando aplicados.

Desta maneira, estudando os nutrientes magnésio, cálcio e potássio no tecido foliar de Brachiaria decumbens adubadas com doses de magnésio, Monteiro et al. (1998) determinaram que sua concentração no tecido foliar aumentou de acordo com o incremento da dose desse nutriente na solução nutritiva, ao mesmo tempo em que a concentração de potássio decrescia com o suprimento de magnésio. Por outro lado, Rodrigues \& Rossiello (1995) demonstraram que o incremento de potássio na solução reduziu significativamente o acúmulo de magnésio em plantas de Brachiaria brizantha cv. Marandu. Do mesmo modo, Andrade et al. (2000) verificaram, em capim Elefante, que a concentração de magnésio nas lâminas foliares decresceu de 1,9 para 1,0 g/kg entre a menor e a maior dose de potássio (16 e $304 \mathrm{~kg} / \mathrm{ha}$ ).

Sendo assim, segundo Mattos \& Monteiro (1998), deve-se atentar à nutrição de plantas com relação ao magnésio quando o potássio for altamente disponibilizado. Gomide (1986) já ressaltava que aplicações maciças de potássio devem ser evitadas para prevenir a absorção de luxo e evitar a interferência na absorção de magnésio e cálcio pela planta. 
Desse modo, Faquin et al. (1994), estudando as limitações nutricionais do capim Colonião, observaram interações entre potássio, cálcio e magnésio, no processo de absorção. As maiores concentrações de cálcio $(9 \mathrm{~g} / \mathrm{kg})$ e de magnésio $(6 \mathrm{~g} / \mathrm{kg})$ foram observadas no tratamento em que o potássio foi omitido. Por outro lado, as concentrações de cálcio e magnésio no tratamento completo foram 5 e $3 \mathrm{~g} / \mathrm{kg}$, respectivamente.

\subsubsection{Reciclagem de nutrientes}

As pastagens tropicais têm características que as distinguem dos sistemas agrícolas e estas têm grande impacto na dinâmica dos nutrientes. Nos sistemas agrícolas de produção, grande quantidade de nutrientes é removida das áreas por meio dos seus produtos. Em pastagens, a maior parte dos nutrientes consumidos retorna ao pasto pelas excretas dos animais, existindo uma grande variação com relação a sua eficiência de reciclagem pela forrageira. Isto ocorre devido à heterogeneidade de distribuição desses excrementos no pasto e à variação da magnitude das perdas de nutrientes por lixiviação, volatilização, fixação e imobilização. Além disso, a presença dos nutrientes no material em senescência e no material morto sobre o solo aumenta a complexidade do ciclo dos nutrientes em ambiente de pastejo.

Monteiro \& Werner (1999) relataram que os nutrientes reciclados no ecossistema de pastagem e sua disponibilidade nos vários segmentos desse ciclo influenciam a produtividade da pastagem. Do mesmo modo, segundo, Sollenberger et al. (2002), a habilidade de entender a dinâmica de nutrientes e o uso desse conhecimento para desenvolver estratégias apropriadas de manejo podem determinar o futuro dos ecossistemas de pastejo nos trópicos.

Neste contexto, na busca de aumentos na produtividade animal em pastejo, a adoção da fertilização como alternativa para intensificar o sistema tem sido imperativa, existindo a tendência de reduzir o ciclo de pastejo e 
aumentar a utilização da forragem, conseqüentemente, aumentando a extração de nutrientes. Assim, torna-se importante o conhecimento das taxas de entrada, saída e ciclagem dos nutrientes, para que sejam traçadas estratégias de adubação visando a fornecer o suprimento adequado de nutrientes e a aumentar a sustentabilidade do sistema (Marcelino \& Fonseca, 2002).

\subsubsection{Consumo e extração}

Os animais em pastejo afetam o ciclo dos nutrientes por meio do consumo dos minerais contidos na forrageira e do retorno destes ao solo pelas fezes e urina. A retenção pelos tecidos e a exportação em produto animal dos nutrientes ingeridos são muito baixas, e a maior parte dos elementos retorna ao solo via excrementos (Sollenberger et al., 2002).

Wilkinson \& Lowrey (1973) trabalharam com pastagem de festuca, manejando o ano todo com 2,47 pares de vaca-bezerro/ha, determinaram o consumo anual de $\mathrm{K}, \mathrm{P}, \mathrm{S}, \mathrm{Ca}$ e $\mathrm{Mg}$ pelos animais por meio do pastejo, sendo 255, 30, 22, 27 e $18 \mathrm{~kg} / \mathrm{ha}$, respectivamente.

Primavesi et al. (2001) determinaram as concentrações dos nutrientes e a extração mineral na forragem de capim Coastcross, relativas à soma das produções de massa seca de cinco cortes em função de doses de nitrogênio. As concentrações dos nutrientes nas doses 0 e $1.000 \mathrm{~kg}$ de $\mathrm{N} / \mathrm{ha}$ nos cinco cortes foram, respectivamente, 16,4 e 30,5, 16,9 e 23,1, 2,8 e 2,5, 3,5 e 2,8, 4,1 e 4,6, 1,9 e 2,6, para nitrogênio, potássio, fósforo, enxofre, cálcio, magnésio em g/kg MS, e 5,7 e 9,6, 21 e 29, 61 e 107, 269 e 159 para cobre, zinco, manganês e ferro, em mg/kg MS. Observa-se, nesse caso, que em geral, as concentrações dos nutrientes não decresceram com o aumento das doses de nitrogênio, demonstrando um equilíbrio nas adubações complementares. A extração mineral nas doses 0 e $1.000 \mathrm{~kg}$ de N/ha nos cinco ciclos foi, respectivamente, 41 e 429, 43 e 392, 7 e 35, 9 e 40, 11 e 67, e 5 e 37 para 
nitrogênio, potássio, fósforo, enxofre, cálcio, magnésio em kg/ha, e 14 e 137, 53 e 410, 151 e 1.431, e 593 e 2.206 para cobre, zinco, manganês e ferro, em g/ha.

Coutinho et al. (2001), estudando o efeito da adubação nitrogenada e potássica na produção de massa seca e composição mineral do capim Coastcross irrigado, determinaram que a extração de N e K, por corte, foi 108 e $63 \mathrm{~kg}$, respectivamente, quando a produção de massa seca foi $4.500 \mathrm{~kg} / \mathrm{ha}$ por corte. Andrade et al. (1996), trabalhando com doses de N e K em Panicum maximum cv. IZ-1, demonstraram que a extração de $\mathrm{K}, \mathrm{P}, \mathrm{Ca}$ e $\mathrm{S}$ foi, respectivamente, $713,61,211$ e $31 \mathrm{~kg} / \mathrm{ha}$ na dose de $753 \mathrm{~kg}$ de $\mathrm{N}$ e $753 \mathrm{~kg}$ de $\mathrm{K}_{2} \mathrm{O} /$ ha durante os sete cortes realizados, produzindo 34,1 t de massa seca por hectare.

São raros os dados, na literatura nacional, relacionados ao consumo de nutrientes por animais em pastejo, explorados intensivamente. Deste modo, a determinação desses valores possibilitará maior eficiência nas determinações de adubações, visto que o consumo de nutrientes é a base para os cálculos de reposição da fertilidade do solo.

\subsubsection{Vias de reciclagem}

A diferença entre a disponibilidade e a perda de nutrientes da liteira e dos excrementos animais auxilia na compreensão da dinâmica dos nutrientes em ecossistemas de pastagens. Os nutrientes são distribuídos mais uniformemente, espacial e temporalmente, por meio da deposição do material vegetal sobre o solo em relação à excreta animal (Haynes \& Williams, 1993). No entanto, a disponibilidade de muitos nutrientes, em especial N e P, pode ser baixa devido à menor qualidade dos capins tropicais. Em contrapartida, os

nutrientes contidos nas fezes e urina são mais prontamente disponíveis à planta, mas são facilmente perdidos, pois tendem a ser depositados em alta 
concentração em pequenas áreas. Saunders (1984) demonstrou que o valor aproximado da quantidade de nutrientes devido à deposição de fezes é 800 , 300, 400, 600, 150 e 100 kg/ha, respectivamente para N, P, K, Ca, Mg e S, e, devido à deposição de urina, 500, 3, 1.000, 5, 4 e 80 kg/ha, respectivamente para os mesmos nutrientes.

Deste modo, os nutrientes contidos no material vegetal depositado no solo e excretas dos animais são importantes fontes no sistema, sendo sua importância relativa dependente do grau de utilização da pastagem. Assim, à medida que se intensifica o sistema de produção, por exemplo, por meio do aumento da taxa de lotação, cresce a proporção de forragem consumida, aumentando a importância da excreta em relação ao material vegetal depositado no solo no retorno dos nutrientes ao solo, conforme demonstra a tendência verificada para a reciclagem de N, ilustrada na Figura 1.

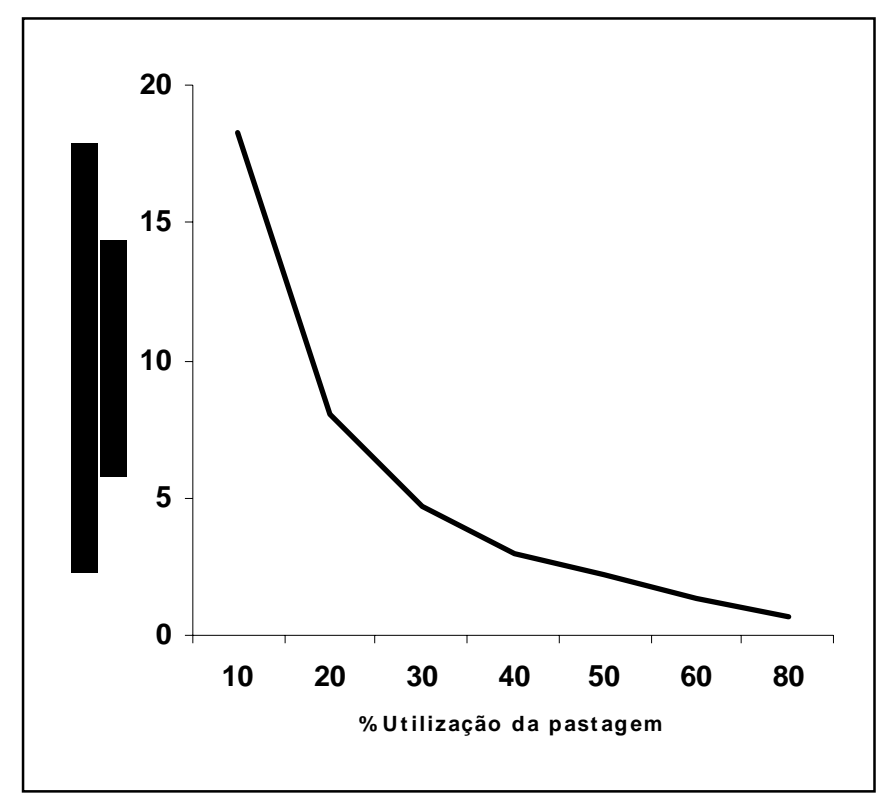

Figura 1 - Variação do retorno do nitrogênio da forragem ao solo, demonstrada a partir da relação $\mathrm{N}$-material vegetal depositado sobre o solo e $\mathrm{N}$ excreta, em função da taxa de utilização da forragem Fonte: Adaptado de Thomas, 1992. 
Neste sentido, segundo Sollenberger et al. (2002), geralmente, a eficiência de pastejo determina se o material vegetal depositado no solo ou a excreta será a principal fonte de carbono do sistema, sendo o entendimento do ciclo do carbono de grande importância, porque a disponibilidade de N, P e S é dependente dos processos de mineralização e imobilização da matéria orgânica, pois esses nutrientes estão associados a compostos orgânicos e atividade microbiana (Cantarutti, 1996).

\subsection{Via excreções}

A quantidade de nutrientes exportados por meio de produtos animais em sistemas de pastejo é muito reduzida em relação ao total reciclado (Wilkinson \& Lorey, 1973). Assim, 60 a 99\% dos nutrientes ingeridos retornam ao pasto na forma de excreta (Barrow, 1987). Neste sentido, segundo Haynes \& Williams (1993), a quantidade de nutrientes retornados ao solo via fezes e urina pode ser estimada conhecendo a quantidade e a composição da forragem consumida e o requerimento de nutrientes pelo animal.

Em sistema intensivo de produção de gado leiteiro na Nova Zelândia, foi estimado que $38 \%$ do fósforo ingerido foram exportados como produto animal, ao passo que, para enxofre e potássio, foram 16 e 5\% do total ingerido, respectivamente (Middleton \& Smith, 1978). Esses autores demonstraram que, em sistema de produção de carne, com produtividade de $500 \mathrm{~kg}$ de PV/ha/ano, a exportação de N, P e K seria 12, 4 e $1 \mathrm{~kg} / \mathrm{ha} / \mathrm{ano}$, respectivamente. De modo geral, a retenção do nutriente consumido varia de 5 a 30\%, com menores valores para ganho corporal e maiores para produção de leite (Russelle, 1997).

A quantidade dos nutrientes que são removidos por meio do pastejo pelos animais proporcionando ganhos e, desta forma, exportados do sistema foi demonstrada por Wilkinson \& Lowrey (1973), sendo a remoção de N, P, K, S, Ca e Mg, respectivamente, 27,2, 6,8, 1,5, 1,5, 12,8 e 0,4 em g/kg de ganho de peso vivo de bovinos. 
Deste modo, os animais não são um grande reservatório de nutrientes, mas são muito importantes em sua reciclagem, pois grande quantidade é ingerida e excretada. Na Nova Zelândia, Williams et al. (1990) estimaram que os animais em pastejo são responsáveis direta e indiretamente por 74 a 92\% das perdas de potássio em pastagens com vacas leiteiras. As perdas diretas pela produção animal são menores $(0,12$ a $0,18 \mathrm{~kg}$ de $\mathrm{K}$ por $100 \mathrm{~kg}$ de produto animal) que as perdas indiretas, associadas a transferência espacial e concentração de potássio, devido ao padrão de deposição de fezes e urina do animal.

Segundo Schomberg et al. (2000), os nutrientes contidos na excreta estão sujeitos a perdas gasosas e por lixiviação, bem como podem ser fixados e imobilizados quimicamente. Deste modo, esses acontecimentos reduzem a eficiência de reciclagem do nutriente em ambientes de pastejo.

Uma micção bovina é equivalente a uma chuva de $5 \mathrm{~mm}$ em uma área de $0,4 \mathrm{~m}^{2}$, sendo, equivalente a $500 \mathrm{~kg}$ de $\mathrm{N} / \mathrm{ha}$ e $1.000 \mathrm{~kg}$ de $\mathrm{K} / \mathrm{ha}$ (Castilla et al. 1995). No local da deposição da urina, o nitrogênio poderá ser perdido por volatilização e o restante que exceder a demanda imediata da planta, provavelmente, será perdido por lixiviação. Além disso, freqüentemente, ocorre lixiviação de $\mathrm{K}^{+}$e $\mathrm{SO}_{4}^{-2}$ (Mathews et al., 1996), e, segundo Ryden (1986) dependendo das condições climáticas e da quantidade de material vegetal depositado no solo (aumento da atividade da urease) no solo, as perdas por volatilização de nitrogênio contido nas fezes e urina podem ser de 4 a $66 \%$. Essas perdas ocorrem, pois o composto nitrogenado predominante na urina de bovinos é a uréia, que ao ser depositada sobre o solo, sofre hidrólise através da ação da enzima urease, gerando amônia. Esta pode ser perdida para a atmosfera, de tal forma que substancial parte de nitrogênio contido na urina pode ser volatilizado. Em pastagens as perdas por volatilização mensuradas em condição de campo variam em função da época do ano, da forma de aplicação e da fonte de fertilizante empregada. Martha Junior (1999) determinou as perdas por volatilização de nitrogênio, utilizando sulfato de amônio e uréia com 
aplicações de $100 \mathrm{Kg}$ de $\mathrm{N} / \mathrm{ha}$ por corte. As perdas quando se utilizou sulfato foram de 21 e 16\% do nitrogênio aplicado, enquanto que para a uréia as perdas foram de 80 a 13\% do nitrogênio aplicado, respectivamente para aplicações realizadas no final do verão e inicio do outono.

Haynes \& Williams (1993), demonstraram que 95, 97, 78, 95 e 98\% do fósforo, cálcio, magnésio, cobre e zinco, respectivamente, foram excretados nas fezes. Neste aspecto, Braz et al. (2001) estudaram a reciclagem de nutrientes pelas fezes de bovinos pastejando a área estabelecida com Brachiaria decumbens, demonstrando que, respectivamente, $77,18,73$ e $63 \%$ do $\mathrm{P}, \mathrm{K}, \mathrm{Ca}$ e $\mathrm{Mg}$ consumidos pelos animais retornaram ao solo via fezes.

$\mathrm{P}, \mathrm{Ca}, \mathrm{Mg}$ e os micronutrientes metálicos ( $\mathrm{Fe}, \mathrm{Cu}, \mathrm{Mn}$ e $\mathrm{Zn}$ ) são excretados preferencialmente via fezes, enquanto $\mathrm{K} \mathrm{e}$, em menor proporção o $\mathrm{Na}$ são excretados preferencialmente pela urina; $\mathrm{N}$ e $\mathrm{S}$ são excretados por ambas as vias, e a participação relativa depende da quantidade na dieta (Mathews et al., 1996), indicando que as vias de excreção são diferentes, propiciando possibilidades de reciclagem diferentes para grupos de nutrientes.

Saunders (1984) estudou a produção, distribuição, composição mineral do solo e da planta em áreas de pastagens, onde ocorreram ou não a deposição de fezes e urina animal, em diferentes solos da Nova Zelândia. As áreas onde ocorreu deposição de excrementos variaram entre as localidades de 27 a $40 \%$ da área total, as quais, no entanto, representaram 70 a $82 \%$ da produção de massa seca, sendo esta de 60 a $360 \mathrm{~kg} \mathrm{MS/ha}$ nas áreas onde não ocorreu a deposição e de 450 a 1.720 kg MS/ha nas áreas onde ocorreu a deposição de fezes e urina. As áreas onde ocorreram deposições de excrementos apresentaram maiores teores de $\mathrm{K}, \mathrm{P}, \mathrm{Ca}, \mathrm{Mg}$ e $\mathrm{S}$ no solo e as plantas tinham maiores concentrações de K, P e Mo, demonstrando a influência das fezes e urina na produção e fertilidade do solo em áreas de pastejo.

Em revisão realizada por Monteiro \& Werner (1999), esses autores concluíram que a distribuição das excreções animais está sujeita a taxa de lotação, forma de pastejo, área de descanso, tipo de animal, quantidade e 
freqüência de excreções, sistema de manejo da pastagem e localização de aguadas e sombra.

Peterson \& Gerrish (1996) sugeriram que altas taxas de lotação e curtos períodos de ocupação aumentam a uniformidade de distribuição. Por outro lado, Mathews et al. (1994) determinaram que a concentração e a distribuição de nutrientes não diferem entre lotação contínua e rotacionada, mas $\mathrm{N}, \mathrm{P}$ e K são acumulados no terço inicial das pastagens, próximo à área de descanso. Neste sentido, Hilder (1966), citado por Monteiro \& Werner (1999), demonstrou que 27 a $35 \%$ das fezes de ovinos se concentravam em $4,4 \%$ da área total da pastagem.

A distribuição de fósforo foi avaliada em pastagens da Flórida, EUA (Sollenberger, dados não publicados, citado por Sollenberger et al. 2002), em lotação rotacionada com vacas de leite por aproximadamente 180 dias durante dois anos, com duas taxas de lotação (3,75 e 6,25 vacas/ha). As vacas receberam suplementação concentrada, o que determinou uma suplementação de $6 \mathrm{~kg}$ de fósforo por vaca/ano e a pastagem não foi adubada com fósforo. As áreas próximas a sombra e água tiveram incrementos do teor de fósforo (Mehlich I) do solo de 25 e $4 \mathrm{~g} / \mathrm{dm}^{3}(0-15 \mathrm{~cm})$, respectivamente para alta e baixa lotação, durante os dois anos de período experimental. Nas áreas mais distantes da sombra e da água, o teor de $P$ aumentou em $7 \mathrm{~g} / \mathrm{dm}^{3}$ para 0 tratamento com alta lotação e decresceu em $10 \mathrm{~g} / \mathrm{dm}^{3}$ no de baixa lotação, demonstrando a capacidade do primeiro de melhorar a redistribuição de $\mathrm{P}$ na pastagem, sugerindo que a taxa de lotação é uma variável importante que afeta a redistribuição dos nutrientes.

Bailey \& Welling (1999) demonstraram que a distribuição de fezes foi influenciada pela localização do cocho de suplementação mineral em sistema de lotação contínua em áreas de 260, 325 e 660 hectares, sendo o número de defecações na área próxima ao suplemento (200 metros) 6,6 vezes maior em relação às da área controle $(0,5$ defecação/100 m²). 
Deste modo, o ambiente de pastejo pode ter um papel importante na determinação do potencial de utilização do manejo da pastagem sobre a distribuição de excretas, tendo este potencial para reduzir o impacto da desuniformidade da distribuição de excreta.

\subsection{Via forragem}

Em ambiente de pastejo, outra fonte de reciclagem importante é composta por partes da planta (aérea e subterrânea) que, por meio da senescência, retornam os nutrientes ao solo durante o ciclo de produção por sua decomposição. Além disso, a forragem derrubada pelos animais durante o pastejo contribui para o incremento dessa via. É importante destacar que a contribuição de nutrientes via forragem apresenta maior uniformidade de distribuição na área de pastagem, quando comparada à contribuição via excreções (Monteiro \& Werner, 1999).

Aspectos que influenciem a taxa de senescência e a quantidade de material que deixa de ser pastejado e tem oportunidade de senescer devem interferir na reciclagem de nutrientes, principalmente daqueles de baixa mobilidade na planta, como Ca, S, B, Zn, entre outros.

A proporção de forragem acumulada que é removida pelos animais antes de iniciar o processo de senescência pode definir a eficiência de utilização da forragem em sistema de pastejo, sendo essa eficiência dependente da extensão do comprimento da folha que escapa da desfolha e deixa de ser consumida (Silva, 2002), ou seja, quanto menor esse comprimento, maior será a eficiência momentânea de pastejo. Assim, Nabinger (1999) indicou que a eficiência de utilização das plantas forrageiras varia em função da freqüência com que é pastejada, ou seja, do intervalo de tempo entre um pastejo e outro, do tempo em que os animais permanecem pastejando a mesma área e da intensidade com que esse pastejo permite a remoção de parte aérea da planta. 
Segundo Mott (1974), a porcentagem de nutrientes reciclada por essa via depende, primeiramente, da quantidade de forragem utilizada pelos animais, bem como da composição química das partes das plantas consumidas pelo animal. A intensidade de utilização da forragem é função, por exemplo, da carga animal empregada, tendo Penati (2002) demonstrado que a eficiência de pastejo em capim Tanzânia irrigado, manejado a 1.000, 2.500 e $4.000 \mathrm{~kg}$ de MSV/ha de resíduo pós-pastejo, equivalente a lotação de 6,5, 5,2 e 4,1 UA/ha, foi 75, 67 e 47\%, respectivamente. Do mesmo modo, Caminha et al. (2002) obtiveram eficiência de pastejo em capim Marandu, em lotação contínua, manejado a 10, 20, 30 e $40 \mathrm{~cm}$ de altura, de 82, 76, 69 e 68\%, respectivamente.

Santos (2002), também manejando capim Tanzânia irrigado, na mesma área experimental que Penati (2002), demonstrou existir maior renovação da população de perfilhos nas áreas submetidas a alta intensidade de pastejo (1.000 kg de MSV/ha de resíduo pós-pastejo).

Deste modo, espera-se que plantas manejadas com maior intensidade tenham maior renovação de tecido e maior eficiência de pastejo, gerando menor quantidade de material senescido, o que determinaria menor reciclagem via forragem como já demonstrado na Figura 1. Ao mesmo tempo, devido à maior renovação, essas áreas devem apresentar maior fertilidade para atender ao maior requerimento nutricional da planta forrageira.

Outro aspecto que pode influenciar as diferenças de reciclagem devidas ao manejo do pastejo empregado é a dinâmica do sistema radicular, pois, segundo Matthews (1992), a paralisação do crescimento e a mortalidade do sistema radicular após a desfolha ocorrem em dependência da intensidade do pastejo. Pagoto (2001), trabalhando com capim Tanzânia irrigado em três intensidades de pastejo, na mesma área experimental que Santos (2002) e Penati (2002), estudou a porcentagem de raízes vivas e mortas nesses tratamentos, demonstrando maior mortalidade para o tratamento submetido ao resíduo de $1.000 \mathrm{~kg} \mathrm{MSV/ha} \mathrm{(alta} \mathrm{intensidade).} \mathrm{Deste} \mathrm{modo,} \mathrm{espera-se} \mathrm{que}$ plantas manejadas intensivamente tenham maior porcentagem da reciclagem 
de nutrientes via sistema radicular, quando comparadas a plantas manejadas com menor intensidade, comportamento este oposto ao observado na reciclagem via material senescente.

Além da senescência, em um sistema de pastejo, existem outros fatores de perdas, como os danos físicos decorrentes do pisoteio ou da queda da forragem durante os processos de escolha, apreensão e manipulação do alimento pelo animal em pastejo (Penati, 2002), e essas perdas também podem influenciar a porcentagem de nutrientes reciclados na área.

No caso dos danos físicos por pisoteio, Quadros et al. (2001) encontraram valores de perdas de até $13,92 \%$ da forragem disponível prépastejo, para o capim Mombaça, quando submetido aos níveis mais altos de adubação, sendo os valores médios ao redor de 7\%. Tosi (1999), em pastagem adubada de capim Tanzânia sob lotação intermitente, obteve valores de 1.415 $\mathrm{kg} \mathrm{MS/ha} \mathrm{por} \mathrm{ciclo} \mathrm{de} \mathrm{pastejo} \mathrm{no} \mathrm{período} \mathrm{de} \mathrm{verão,} \mathrm{sendo} \mathrm{o} \mathrm{valor} \mathrm{médio} \mathrm{anual}$ $1.050 \mathrm{~kg} \mathrm{MS} / \mathrm{ha}$ por ciclo de pastejo (28\% da massa de forragem média prépastejo). Penati (2002), trabalhando em áreas irrigadas de capim Tanzânia sob pastejo, determinou a quantidade de forragem perdida em função dos tratamentos, obtendo valores de 624, 1.175 e $1.720 \mathrm{~kg}$ de massa seca por hectare por ciclo, respectivamente, para os tratamentos de alta, média e baixa intensidade de pastejo. Do mesmo modo, Castilla et al. (1995) estudaram o efeito de duas taxas de lotação (3,3 e 8,3 animais/ha) em áreas com produções de massa seca semelhantes, demonstrando que a quantidade de material vegetal depositado sobre o solo decresceu em função do aumento da taxa de lotação.

Sendo assim, principalmente em condições de alta produção de forragem, deve-se atentar para as perdas da forragem por pisoteio, uma vez que podem ser ainda maiores que aquelas por senescência.

De acordo com Wilkinson \& Lowrey (1973), em pastagens de festuca manejado com 2,47 vacas com bezerro ao pé por hectare o ano todo, sem uso de insumos em área recém-utilizada com cultura anual, o retorno do potássio, 
fósforo, enxofre, cálcio e magnésio, decorrente de forragem não pastejada e tecidos mortos de raízes das plantas, foi 97,3, 12,1, 10,1, 13,7 e 9,0 kg/ha/ano, respectivamente.

Além da quantidade, a qualidade do resíduo das plantas que retornam ao solo regula o ciclo dos nutrientes em pastagens. Neste sentido, a taxa relativa de decomposição (TRD) é um importante parâmetro de reciclagem e disponibilidade dos nutrientes, sendo, segundo Myers et al. (1994), as características-chave da qualidade do material vegetal depositado no solo, englobando suas propriedades físicas e composição química, principalmente as concentrações e relações $\mathrm{N}, \mathrm{P}, \mathrm{C}$, lignina e polifenóis.

A concentração de fósforo de $2 \mathrm{~g} / \mathrm{kg}$ MS de resíduos da forrageira é considerada limiar entre o balanço do processo de mineralização e imobilização; em concentrações inferiores, há predominância de imobilização (Sollenberger et al., 2002).

Neste sentido, em trabalho realizado por Resende et al. (1999), com pastagens de Brachiaria humidicola, consorciada ou não com Desmodium ovalifolium, os autores demonstraram que o material sobre o solo da pastagem consorciada se decompôs mais rapidamente em relação ao do monocultivo, podendo ser esse resultado decorrente da melhor qualidade do material, devido à presença da leguminosa, que proporcionou maiores concentrações de nitrogênio, refletindo-se em menor relação $\mathrm{C} / \mathrm{N}$. Dessa maneira, a decomposição do material sobre o solo variou de 0,071 a 0,08 g/g/dia. Neste aspecto, segundo Barbosa (1999), citado por Marcelino \& Fonseca (2002), a concentração de minerais no material depositado sobre o solo é função da disponibilidade de nutrientes para as plantas. Sendo a disponibilidade alta, o vegetal produzirá uma camada de material depositado rica em nutrientes, que se decomporá rapidamente.

Deste modo, segundo Sollenberger et al. (2002), em ecossistemas de pastagens, a deposição e a decomposição dos resíduos das plantas durante a estação de crescimento exercem influência contínua no suprimento de 
nutrientes à forrageira, em especial $\mathrm{N}, \mathrm{P}$ e $\mathrm{S}$, pois sua disponibilidade está em parte controlada por processos biológicos.

Assim, a decomposição do material morto proveniente das plantas e das excretas do animal é um dos principais fatores que influenciam a reciclagem dos nutrientes em ambiente de pastejo, já que os minerais podem ser imobilizados ou não pela microbiota durante o processo de decomposição (Marcelino \& Fonseca, 2002).

\subsubsection{Nutrição da planta}

A intensidade de pastejo influencia a produção e a disponibilidade de forragem, a morfogênese, a dinâmica do sistema radicular, a reciclagem de nutrientes e fatores relacionados à física do solo, como a compactação, portanto, deve-se esperar que a intensidade de pastejo influencie o requerimento de minerais pela planta, interferindo nas avaliações nutricionais da forrageira.

Desse modo, Harris (1978), citado por Pagoto (2001), inferiu que o aumento da severidade dos cortes poderia afetar negativamente o consumo de nutrientes pelas plantas, em função de fatores como a redução do sistema radicular em decorrência da desfolha, podendo limitar a exploração de água e nutrientes do solo; a diminuição da transpiração, restringindo a absorção de nutrientes e a restrição do fluxo de fotossintetizados e, conseqüentemente, os substratos para a respiração das raízes, limitando a absorção ativa de nutrientes.

Cecato et al. (2001) estudaram os níveis de Ca, P, K, Mg na composição do capim Tanzânia manejado em lotação contínua e em diferentes alturas (20, 40, 60 e $80 \mathrm{~cm}$ ). As concentrações de Ca nas lâminas foliares apresentaram comportamento linear e crescente em relação à altura do pasto e ao período de coleta, com interação das variáveis altura e período, sendo este compreendido 
entre janeiro e maio de 1999. Nos colmos, a concentração de Ca decresceu em função do período de amostragem. A concentração média de Ca observada nas lâminas oscilou entre 4,1 e 5,4 g/kg MS, enquanto os colmos apresentaram valores inferiores e variaram entre 3,2 e 4,2 $\mathrm{g} / \mathrm{kg} \mathrm{MS}$ ao longo do período experimental. A concentração de $P$ variou entre 4,2 e 4,9 g/kg MS nas lâminas, decrescendo em função do período de amostragem, não sendo influenciada pela altura. Já a concentração do colmo mais bainha apresentou valores entre 3,5 e $3,8 \mathrm{~g} / \mathrm{kg} \mathrm{MS}$, decrescendo com o aumento da altura de pastejo. As concentrações de $\mathrm{K}$, independentes da parte, foram influenciadas pelo período de coleta, decrescendo com seu avanço e apresentando valores de $28 \mathrm{~g} / \mathrm{kg} \mathrm{MS}$ para ambas as partes. As concentrações de Mg apresentaram comportamento linear decrescente com o aumento da altura de pastejo, variando de 2,4 a 3,2 g/kg MS.

Do mesmo modo, a concentração média de $\mathrm{P}$ encontrada nas lâminas de capim Elefante anão Mott por Almeida et al. (2000) apresentou comportamento linear decrescente no decorrer do período experimental, sendo este compreendido entre outubro de 1994 a abril de 1995, e não indicou efeito da altura da forragem pós-pastejo. Com relação aos colmos, estes apresentaram decréscimos nos níveis de $\mathrm{P}$ com incrementos na altura da planta, e seus níveis foram semelhantes ao longo das coletas. A concentração média de $P$ nas lâminas variou de 4,9 a 4,2 $\mathrm{g} / \mathrm{kg}$ MS do período inicial até o final da avaliação. Já a fração colmo, oscilou de 3,8 a 3,5 g/kg MS para as alturas 24 e $78 \mathrm{~cm}$, respectivamente.

Ribeiro et al. (1999), trabalhando com adubação nitrogenada em capim Elefante cv. Mott, pastejado sob manejo rotacionado ao atingir 80 e $120 \mathrm{~cm}$ de altura, observaram diferenças na concentração de nitrogênio nas lâminas de folhas nos tratamentos de 80 e $120 \mathrm{~cm}$, no primeiro e no segundo período. As concentrações de nitrogênio nas lâminas foram 15,8 e 18,2 g/kg MS e 14,5 e $16,4 \mathrm{~g} / \mathrm{kg} \mathrm{MS}$, no primeiro e no segundo corte, para 80 e $120 \mathrm{~cm}$, respectivamente. As concentrações do nutriente no colmo mais bainha foram 
12,6 e 13,2 g/kg MS e 11,2 e 6,8 g/kg MS, no segundo e no terceiro corte, para 80 e $120 \mathrm{~cm}$, respectivamente. A concentração de nitrogênio nas lâminas aumentou com o suceder de cortes, fato este interpretado como efeito residual do adubo nitrogenado e/ou queda do rendimento forrageiro. A concentração nos colmos mais bainhas foi reduzida no último corte em plantas colhidas ao atingirem $120 \mathrm{~cm}$, provavelmente, devido à intensificação do alongamento dos colmos e, conseqüentemente, à diluição do conteúdo celular. Por outro lado, as concentrações de fósforo não variaram em função da altura em todas as partes estudadas. Nos tratamentos de $80 \mathrm{~cm}$, a concentração de potássio foi maior nos colmos mais bainhas (43,2 g/kg MS) em relação às lâminas (27,7 g/kg MS). Houve diferença na concentração de potássio nos colmos entre os tratamentos, sendo 43,2 g/kg MS no tratamento de $80 \mathrm{~cm}$ e $29,2 \mathrm{~g} / \mathrm{kg}$ MS no de $120 \mathrm{~cm}$. A concentração de cálcio não variou com os tratamentos, mas apresentou concentrações baixas, variando de 2,4 a 3,7 g/kg MS nas lâminas e 3,2 g/kg MS nos colmos.

Conclui-se que intensidade de pastejo, época do ano e idade da planta afetam diferentemente as concentrações de nutrientes em diversas partes da planta. Entretanto, os trabalhos realizados com nutrição de plantas forrageiras não consideram o efeito do pastejo na determinação dos níveis críticos ou faixa de suficiência, ou ainda na escolha da parte da planta que melhor correlaciona concentração do nutriente na planta e produtividade. Deste modo, estudos que determinem a influência da intensidade de pastejo na concentração e na relação dos minerais em diferentes partes da planta, quando o déficit hídrico é eliminado e a fertilidade do solo é elevada, devem promover resultados que propiciem maior segurança na utilização de ferramentas de planejamento, avaliação e calibração da adubação para gramíneas tropicais exploradas para produção intensiva em pastagens tropicais irrigadas. 


\section{MATERIAL E MÉTODOS}

\subsection{Primeiro ano experimental}

\subsubsection{Local do experimento}

Esse trabalho foi desenvolvido entre 30 de outubro de 1999 e 24 de outubro de 2000 em Piracicaba, SP, em área estabelecida em 4,8 ha com Panicum maximum Jacq. cv. Tanzânia sob pivô central, pertencente ao Departamento de Engenharia Rural da ESALQ/USP, nas coordenadas geográficas de $22^{\circ} 42^{\prime} 30^{\prime \prime}$ latitude sul e $47^{\circ} 38^{\prime} 30^{\prime \prime}$ longitude oeste a 580 metros de altitude.

\subsubsection{Clima}

As condições climáticas da área experimental podem ser avaliadas através da Tabela 1. A média da precipitação anual de 1999 e 2000 em Piracicaba foi $1.390 \mathrm{~mm}$. 
Tabela 1. Dados de temperatura e insolação medidos na estação meteorológica da ESALQ durante o período experimental, localizada a 500 metros da área experimental

\begin{tabular}{cccccc}
\hline Ano & Mês & Insolação & \multicolumn{3}{c}{ Temperatura média diária ( ${ }^{\circ}$ C) } \\
& & Horas/Dia & Máxima & Mínima & Média \\
\hline 1999 & Outubro & 6,98 & 28,5 & 15,4 & 21,9 \\
1999 & Novembro & 7,04 & 29,5 & 15,7 & 22,6 \\
1999 & Dezembro & 7,23 & 30,6 & 19,0 & 24,8 \\
2000 & Janeiro & 6,37 & 30,2 & 19,9 & 24,6 \\
2000 & Fevereiro & 5,49 & 29,9 & 19,2 & 24,6 \\
2000 & Março & 5,42 & 29,7 & 18,5 & 24,1 \\
2000 & Abril & 9,08 & 29,4 & 14,5 & 21,9 \\
2000 & Maio & 7,36 & 26,6 & 11,2 & 18,9 \\
2000 & Junho & 6,68 & 27,2 & 11,4 & 19,3 \\
2000 & Julho & 6,47 & 24,7 & 8,8 & 16,6 \\
2000 & Agosto & 5,74 & 26,5 & 12,5 & 19,5 \\
2000 & Setembro & 6,17 & 27,2 & 15,1 & 21,1 \\
2000 & Outubro & 7,20 & 32,1 & 18,0 & 25,0 \\
2000 & Novembro & 6,79 & 29,8 & 17,7 & 23,8 \\
\hline
\end{tabular}

\subsubsection{Solo}

O preparo do solo foi realizado com uma gradagem utilizando grade aradora e duas gradagens empregando grade niveladora. A semeadura foi realizada a 17 de março de 1999, a um espaçamento de $17 \mathrm{~cm}$ entre linha. Para o estabelecimento da pastagem, foram utilizados 1,5 tonelada de calcário (PRNT $=65 \%$ ) para atingir $80 \%$ da saturação de bases, $3 \mathrm{~kg} / \mathrm{ha}$ de sementes puras viáveis de capim Panicum maximum cv. Tanzânia, $135 \mathrm{~kg} / \mathrm{ha}$ de $\mathrm{P}_{2} \mathrm{O}_{5}$ na 
forma de superfosfato simples, $210 \mathrm{~kg} / \mathrm{ha} \mathrm{K}_{2} \mathrm{O}$ na forma de cloreto de potássio e 75 kg/ha de FTE-BR 12.

O calcário foi distribuído antes da gradagem, e o cloreto de potássio com o FTE foram aplicados entre as duas operações da grade niveladora. $O$ superfosfato simples foi aplicado em linha, próximo à semente, durante a semeadura. Após 15 dias de emergência, foi realizada uma adubação de cobertura com $45 \mathrm{~kg} / \mathrm{ha}$ de nitrogênio na forma de uréia.

Após o primeiro ciclo de pastejo, foram coletadas amostras de terra para acompanhar a evolução da fertilidade do solo. Para compor as amostras, foram coletadas 12 subamostras para cada tratamento por bloco. Os resultados das análises químicas das amostras estão na Tabela 2.

Tabela 2. Análise química da terra da área experimental, coletada em janeiro de 2000, na camada de 0 a $20 \mathrm{~cm}$

\begin{tabular}{|c|c|c|c|c|c|c|c|c|c|c|c|c|c|}
\hline Trat.* & M.O. & P & S-SO4 & K & $\mathrm{Ca}$ & $\mathrm{Mg}$ & T & V & B & $\mathrm{Cu}$ & $\mathrm{Mn}$ & $\mathrm{Zn}$ & $\mathrm{Fe}$ \\
\hline & $\mathrm{g} / \mathrm{dm}^{3}$ & \multicolumn{2}{|c|}{$--\mathrm{mg} / \mathrm{dm}^{3}--$} & \multicolumn{4}{|c|}{---------mmolc/dm³'------ } & $\%$ & \multicolumn{5}{|c|}{----------------mg/dm³'------------- } \\
\hline Alta & 25 & 20 & 30 & 4.9 & 46 & 24 & 110 & 65 & 0.46 & 5.2 & 44 & 4.7 & 52 \\
\hline Média & 25 & 18 & 31 & 4.4 & 39 & 19 & 96 & 64 & 0.49 & 5.1 & 49 & 5.7 & 40 \\
\hline Baixa & 24 & 18 & 29 & 3.4 & 36 & 19 & 96 & 60 & 0.40 & 4.3 & 47 & 4.1 & 46 \\
\hline
\end{tabular}

* Alta intensidade de pastejo - $1.000 \mathrm{~kg} \mathrm{MSV/ha} \mathrm{de} \mathrm{resíduo} \mathrm{pós-pastejo;} \mathrm{Média} \mathrm{intensidade} \mathrm{de} \mathrm{pastejo} \mathrm{-} 2.500 \mathrm{~kg}$ MSV/ha de resíduo pós-pastejo; Baixa intensidade de pastejo - 4.000 kg MSV/ha de resíduo pós-pastejo.

Ao final do experimento, foi realizada outra análise da terra, que pode ser observada na Tabela 3. 
Tabela 3. Análise química da terra da área experimental, coletada em fevereiro de 2001, na camada de 0 a $20 \mathrm{~cm}$

\begin{tabular}{|c|c|c|c|c|c|c|c|c|c|c|c|c|c|}
\hline Trat. * & M.O. & $\mathrm{P}$ & S-SO4 & $\mathrm{K}$ & $\mathrm{Ca}$ & $\mathrm{Mg}$ & $\mathrm{T}$ & V & B & $\mathrm{Cu}$ & $\mathrm{Mn}$ & $\mathrm{Zn}$ & $\mathrm{Fe}$ \\
\hline & $\mathrm{g} / \mathrm{dm}^{3}$ & \multicolumn{2}{|c|}{$----m g / \mathrm{dm}^{3}---$} & \multicolumn{4}{|c|}{-----------mmolc/dm³'------ } & $\%$ & \multicolumn{5}{|c|}{------------'mg/dm } \\
\hline Alta & 30 & 32 & 37 & 7.1 & 38 & 19 & 97 & 67 & 0.39 & 5.8 & 55 & 5.3 & 57 \\
\hline Média & 32 & 33 & 31 & 7.1 & 36 & 20 & 98 & 64 & 0.41 & 6.6 & 65 & 6.2 & 54 \\
\hline Baixa & 31 & 25 & 32 & 5.7 & 42 & 21 & 101 & 67 & 0.23 & 5.7 & 76 & 5.3 & 58 \\
\hline
\end{tabular}

* Alta intensidade de pastejo - $1.000 \mathrm{~kg}$ MSV/ha de resíduo pós-pastejo; Média intensidade de pastejo - $2.500 \mathrm{~kg}$ MSV/ha de resíduo pós-pastejo; Baixa intensidade de pastejo - 4.000 kg MSV/ha de resíduo pós-pastejo.

\subsubsection{Tratamentos}

O delineamento experimental foi em blocos completos ao acaso, com três tratamentos (intensidade de pastejo) e quatro repetições, ao longo de dez ciclos de pastejo de 36 dias. Os tratamentos foram constituídos por três níveis de resíduo pós-pastejo (1.000, 2.500 e 4.000 kg de matéria seca verde/ha), denominados de intensidades de pastejo alta (T1), média (T2) e baixa (T3), respectivamente.

\subsubsection{Instalação e condução do experimento}

Neste experimento, utilizou-se uma área experimental de 4,8 ha, dividida em 12 parcelas de 0,4 ha, em formato de "fatias de pizza", sendo cada "fatia" subdividida em três (piquetes $A, B$ e C), a fim de permitir um ciclo de pastejo de 36 dias com três dias de ocupação, como pode ser observado na Figura 2. 


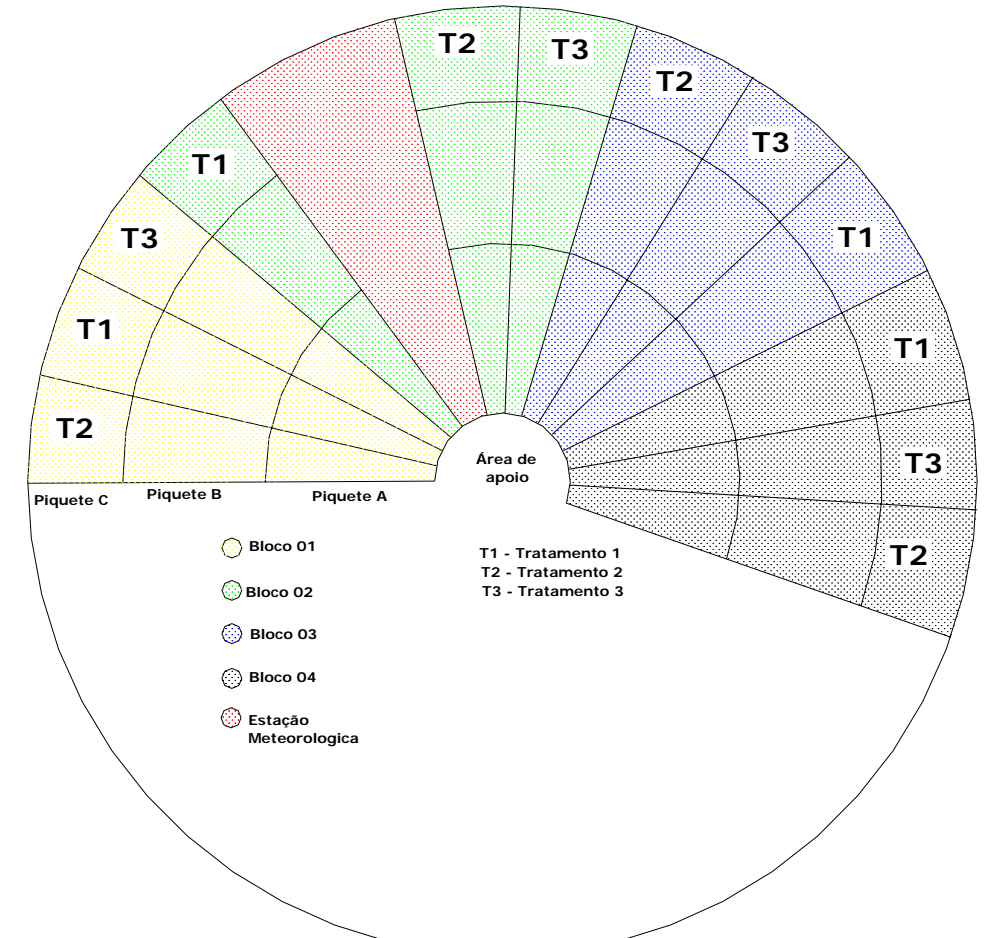

Figura 2 - Croqui da área experimental indicando as respectivas faixas dos tratamentos, blocos e dos piquetes $\mathrm{A}, \mathrm{B}$ e $\mathrm{C}$

A pastagem de capim Tanzânia foi formada em março de 1999, sendo o pastejo de uniformização iniciado em agosto de 1999 e, em seguida, os pastejos foram definidos para acertar as intensidades de pastejo até que o período experimental pudesse ser iniciado a 30 de outubro de 1999.

As adubações para produção de forragem foram parceladas e aplicadas logo após o pastejo, com $334 \mathrm{~kg}$ da fórmula 24-04-24 por hectare por ciclo de pastejo em todos os ciclos, totalizando $800 \mathrm{~kg}$ de N, $134 \mathrm{~kg}$ de $\mathrm{P}_{2} \mathrm{O}_{5}$ e $800 \mathrm{~kg}$ de $\mathrm{K}_{2} \mathrm{O}$ por hectare nos dez ciclos de pastejo.

A estimativa de massa de forragem pré-pastejo foi realizada conforme Penati et al. (2001). A determinação da massa de forragem nos piquetes foi feita a partir de cinco amostragens por piquete em área de $1 \mathrm{~m} \times 1 \mathrm{~m}$ a $5 \mathrm{~cm}$ do solo. As unidades amostrais, ou seja, as molduras de ferro de $1 \mathrm{~m} \times 1 \mathrm{~m}$, foram colocadas nos piquetes de forma sistemática, através de uma linha transecta, 
para evitar que, ao longo do período experimental, ocorresse a sobreposição das unidades de amostragem. Essas avaliações precederam a entrada dos animais nos piquetes. A massa de forragem pós-pastejo foi estimada ao término de cada pastejo com as mesmas freqüência e metodologia utilizadas para determinar a massa de forragem pré-pastejo.

A lotação animal foi ajustada diariamente em função dos níveis de massa de forragem pré e pós-pastejo, conforme Penati (2002).

O manejo da irrigação foi realizado com base no do potencial hídrico do solo, cujo monitoramento foi realizado por tensiômetros digitais de punção instalados em dez baterias, posicionadas nas profundidades de 10, 20, 40, 60, 80 e $100 \mathrm{~cm}$. O potencial hídrico médio foi mantido em valores superiores a $-0,05 \mathrm{Mpa}$, sendo as irrigações realizadas quando os tensiômetros instalados a $20 \mathrm{~cm}$ indicavam valores médios na faixa de -0,3 a -0,4 Mpa de tensão de água no solo (Lourenço et al., 2001).

As amostras destinadas à avaliação do estado nutricional da planta foram feitas a partir de amostragens ao acaso de plantas cortadas a $5 \mathrm{~cm}$ do solo, precedendo a entrada dos animais nos piquetes, durante dez ciclos de pastejo. Também foram coletadas amostras de forragem por meio de simulação de pastejo, nos mesmos períodos de coleta das amostras destinadas à avaliação do estado nutricional da planta. O pastejo simulado foi realizado com base na coleta manual e seletiva da forragem, observando a altura e a estrutura do resíduo do pastejo realizado no dia anterior. Cada amostra, tanto destinada à avaliação do estado nutricional quanto de pastejo simulado, era composta de 20 subamostras.

Em laboratório, após a coleta das amostras no campo, foi feita a separação das partes da planta em folhas emergentes (FE), isto é, lâminas de folhas que não apresentavam lígula visível; lâminas das duas folhas recémexpandidas (LFER), compreendendo as duas folhas superiores totalmente expandidas e apresentando lígula visível; lâminas das folhas maduras (LFM), representadas pelas lâminas das folhas restantes totalmente expandidas e com 
lígula visível, inclusive as folhas senescentes e colmo mais bainha (CB), bem como os senescidos do capim Tanzânia irrigado. Após a separação, o material foi pesado e secado em estufa a $65^{\circ} \mathrm{C}$, a fim de determinar a porcentagem de cada componente da planta na massa seca. Essas amostras foram utilizadas para determinação da concentração dos macro e micronutrientes. A concentração desses minerais na PT (planta toda) foi estimada por meio da ponderação das concentrações e das proporções das partes da planta.

O consumo animal de minerais por hectare foi estimado com base no produto de três variáveis, sendo estas: o consumo animal, determinado por Balsalobre (2002); a lotação animal determinada por Penati (2002); e a concentração dos minerais no pastejo simulado, determinada neste experimento (fórmula I). As determinações de consumo e lotação foram realizadas na mesma área e no mesmo período deste experimento, possibilitando a utilização dos dados.

$C A M=C A * L A * C M P S$

(fórmula I)

Onde:

CAM - Consumo animal de minerais por hectare $\left(\mathrm{kg}^{\star} \mathrm{ha} \mathrm{C}^{-1}\right)$

$\mathrm{CA}$ - Consumo animal (kg MS*UA $\left.{ }^{-1}\right)$

LA - Lotação animal (UA*ha-1)

CMPS- Concentração dos minerais no pastejo simulado ( $\mathrm{kg}$ do mineral*kg ${ }^{*} \mathrm{MS}^{-1}$ )

A estimativa da quantidade de minerais que retornaram via excreta animal (fezes e urina) foi realizada a partir da compilação dos seguintes dados: produtividade animal e concentração de minerais no produto animal, estimando a quantidade de minerais extraída do sistema via produto animal (carne). Dessa maneira, a quantidade de minerais que retornou ao solo via excreta animal foi a diferença entre o consumo animal de minerais e a quantidade de minerais extraída do sistema via produto animal (fórmula II). 
RMVE $=$ CAM $-(P R O D * C M P R O)$

(fórmula II)

Onde:

RMVE - Retorno de minerais via excreta $\left(\mathrm{kg}^{\star} \mathrm{ha}^{-1}\right)$

CAM - Consumo animal de minerais por hectare $\left(\mathrm{kg}^{\star} \mathrm{ha}^{-1}\right)$

PROD - Produtividade animal (kg PV*ha $\left.{ }^{-1}\right)$

CMPRO - Concentração de minerais no produto animal ( $\mathrm{kg}$ minerais*kg PV ${ }^{-1}$ )

A metodologia de cálculo foi baseada no trabalho realizado por Mays et al. (1980). As concentrações utilizadas de minerais no produto animal foram determinadas por Wilkinson \& Lowrey (1973), sendo: 0,0272; 0,0068; 0,0015; 0,$0015 ; 0,0128$; e $0,0004 \mathrm{em} \mathrm{kg} / \mathrm{kg}$ de ganho de peso vivo de bovinos na fase de recria, respectivamente para N, P, K, S, Ca e Mg.

Com o objetivo de testar os valores propostos por Wilkinson \& Lowrey (1973), realizou-se quatro simulações no programa CNCPS v. 4.0 da Universidade de Cornell. A caracterização dos animais e seus desempenhos podem ser observados na Tabela 4.

Tabela 4. Caracterização dos animais e seus respectivos consumos de massa seca e ganho de peso nas diferentes simulações realizadas

\begin{tabular}{ccccc}
\hline Simulação & $\begin{array}{c}\text { Idade } \\
\text { Meses }\end{array}$ & $\begin{array}{c}\text { Peso vivo } \\
\mathrm{kg}\end{array}$ & $\begin{array}{c}\text { Ganho } \\
\mathrm{kg}^{\star} \mathrm{PV}^{-1 \star} \text { animal }\end{array} \mathrm{Cdia}^{-2 *}$ & $\begin{array}{c}\text { Consumo } \\
\mathrm{kg} \mathrm{MS}^{\star} \mathrm{animal}^{-1 \star} \mathrm{dia}^{-2}\end{array}$ \\
\hline 01 & 18 & 300 & 0,38 & 6,00 \\
02 & 18 & 300 & 0,57 & 7,16 \\
03 & 36 & 520 & 0,38 & 9,20 \\
04 & 36 & 520 & 0,57 & 11,00 \\
\hline
\end{tabular}


Os resultados das simulações são apresentados na Tabela 5. Observouse pouca variação na concentração de minerais nos diferentes ganhos de peso. Com relação às diferenças de concentração de minerais nos animais mais velhos, em fase de terminação e nos mais novos (18 meses), constatou-se que apenas as concentrações de nitrogênio demonstraram variações. Desse modo, como este experimento utilizou animais em fase de recria, o emprego dos dados de Wilkinson \& Lowrey (1973) pode ser considerado satisfatório.

Tabela 5. Concentração de minerais via produto animal (ganho de peso) nas quatro simulações realizadas

\begin{tabular}{|c|c|c|c|c|c|}
\hline Simulacãn & Nitrogênio & Fósforo & Potássio & Cálcio & Magnésio \\
\hline 01 & 28,18 & 6,92 & 1,58 & 12,86 & 0,39 \\
\hline 02 & 27,60 & 6,99 & 1,59 & 12,98 & 0,40 \\
\hline 03 & 20,65 & 6,94 & 1,58 & 12,90 & 0,39 \\
\hline 04 & 20,20 & 7,06 & 1,61 & 13,11 & 0,40 \\
\hline Utilizado* & 27,20 & 6,80 & 1,50 & 12,80 & 0,40 \\
\hline
\end{tabular}

* Dados utilizados para retorno de minerais via excreta, determinados por Wilkinson \& Lowrey (1973).

A estimativa da porcentagem de minerais que retornou ao solo via excreta em relação à quantidade de minerais contida na massa de forragem pré-pastejo foi calculada a partir da quantidade de minerais que retornou ao solo via excreta e da quantidade de minerais por hectare na massa de forragem pré-pastejo (produto entre a massa seca pré-pastejo e a concentração dos minerais na massa seca pré-pastejo), empregando-se a fórmula III. 
Onde:

PMRVE - Porcentagem de minerais que retorna ao solo via excreta em relação à quantidade de minerais em pré-pastejo (\%) RMVE - Retorno de minerais via excreta $\left(\mathrm{kg}^{\star} \mathrm{ha}^{-1}\right)$ MFPP - Massa de forragem em pré-pastejo $\left(\mathrm{kg} \mathrm{MS}^{*} \mathrm{ha}^{-1}\right)$

CMFPP - Concentração de minerais na massa de forragem em pré-pastejo (kg de minerais*kg MS ${ }^{-1}$ )

Neste experimento, foi avaliado o efeito do manejo do pastejo e do período sobre: a concentração e as relações dos minerais e do nitrogênio na forma de nitrato em diferentes partes do capim Tanzânia irrigado e adubado ao longo dos ciclos de pastejo; o consumo de minerais em cada ciclo de pastejo; e a quantidade de minerais que retornou ao solo via excremento animal. Determinou-se, também, a porcentagem de minerais que retornou ao solo via excreta animal em relação ao total de minerais contidos na massa de forragem pré-pastejo.

Estudos fenológicos (Pagoto, 2001; Penati, 2002; Santos, 2002), de física do solo (Da Silva et al. 2003 e 2004) e determinações de consumo de matéria seca (Balsalobre, 2002), desenvolvidos em outros projetos que compuseram o Projeto CAPIM (Projeto Temático Fapesp 98/0805-5), foram utilizados para realização de estimativas e para auxiliarem na interpretação dos resultados desta pesquisa. A Tabela 6 demonstra os dados desses estudos utilizados nas estimativas realizadas deste experimento. 
Tabela 6. Determinações utilizadas nas estimativas realizadas neste experimento

\begin{tabular}{lccc}
\hline \multicolumn{1}{c}{ Determinações* } & \multicolumn{3}{c}{ Intensidade de pastejo } \\
& Alta & Média & Baixa \\
\hline Massa de forragem pré-pastejo (kg MS/ha) & 4092 & 6902 & 7778 \\
Produtividade (kg PV/ha) & 137 & 134 & 121 \\
Lotação (UA/ha) $^{\star \star}$ & 6,5 & 5,2 & 4,1 \\
Consumo (kg MS/100 kg PV) ${ }^{\star \star \star}$ & 1,85 & 2,00 & 2,01 \\
\hline
\end{tabular}

* Valores por ciclo de pastejo, ${ }^{* *}$ Penati (2002), ${ }^{* \star *}$ Balsalobre (2002).

As interpretações dos resultados da análise da terra e da composição mineral das partes da planta foram baseadas nos métodos dos níveis críticos e faixas de suficiência.

\subsubsection{Análise estatística}

Os ciclos de pastejo foram agrupados em períodos, apresentados na Tabela 7. Dessa maneira, ao invés de dez ciclos, têm-se três períodos que resumem os resultados dos ciclos que os compõem. 
Tabela 7. Distribuição dos ciclos de pastejo nos períodos e suas respectivas épocas de ocorrência

\begin{tabular}{cccc}
\hline \multirow{2}{*}{ Períodos } & Ciclos & \multicolumn{2}{c}{ Épocas } \\
& & & \\
\hline \multirow{2}{*}{1} & 2 & $30 / 10 / 99$ & $04 / 12 / 99$ \\
& 3 & $05 / 12 / 99$ & $09 / 01 / 00$ \\
& & $10 / 01 / 00$ & $1402 / 00$ \\
& 4 & $15 / 02 / 00$ & $21 / 03 / 00$ \\
2 & 5 & $22 / 03 / 00$ & $26 / 04 / 00$ \\
& 6 & $27 / 04 / 00$ & $01 / 06 / 00$ \\
& & & \\
& 7 & $02 / 06 / 00$ & $07 / 07 / 00$ \\
& 8 & $08 / 07 / 00$ & $12 / 08 / 00$ \\
& 9 & $13 / 08 / 00$ & $17 / 09 / 00$ \\
& 10 & $18 / 09 / 00$ & $23 / 10 / 00$ \\
\hline
\end{tabular}

Inicialmente, foi realizada uma análise exploratória para verificar as pressuposições do modelo estatístico, para, então, efetuar a análise de perfis dos dados resultantes de um delineamento em blocos completos, a fim de estudar o comportamento dos tratamentos ao longo dos períodos.

Quando houve interação entre tratamento e períodos, foram comparadas as médias de tratamentos dentro de cada período, bem como de períodos dentro de cada tratamento. O nível de significância utilizado nas comparações foi 5\%. Para essas análises, foi utilizado o PROC MIXED do SAS (1999). As regressões lineares foram analisadas por meio do PROC REG do SAS (1999) e os níveis de significância utilizados nas comparações foram 1, 5 e 10 \%. 


\subsection{Segundo ano experimental}

\subsubsection{Local do experimento}

Dois experimentos, um irrigado e outro em sequeiro, foram desenvolvidos entre 23 de fevereiro de 2002 e 4 de janeiro de 2003 em Piracicaba, SP, em área estabelecida em 3,2 ha com Panicum maximum Jacq. cv. Tanzânia sob pivô central, pertencente ao Departamento de Engenharia Rural da ESALQ/USP, nas coordenadas geográficas de $22^{\circ} 42^{\prime} 30^{\prime \prime}$ latitude sul e $47^{\circ} 38$ '30" longitude oeste a 580 metros de altitude.

\subsubsection{Clima}

As condições climáticas da área experimental podem ser avaliadas com base na Figura 3.
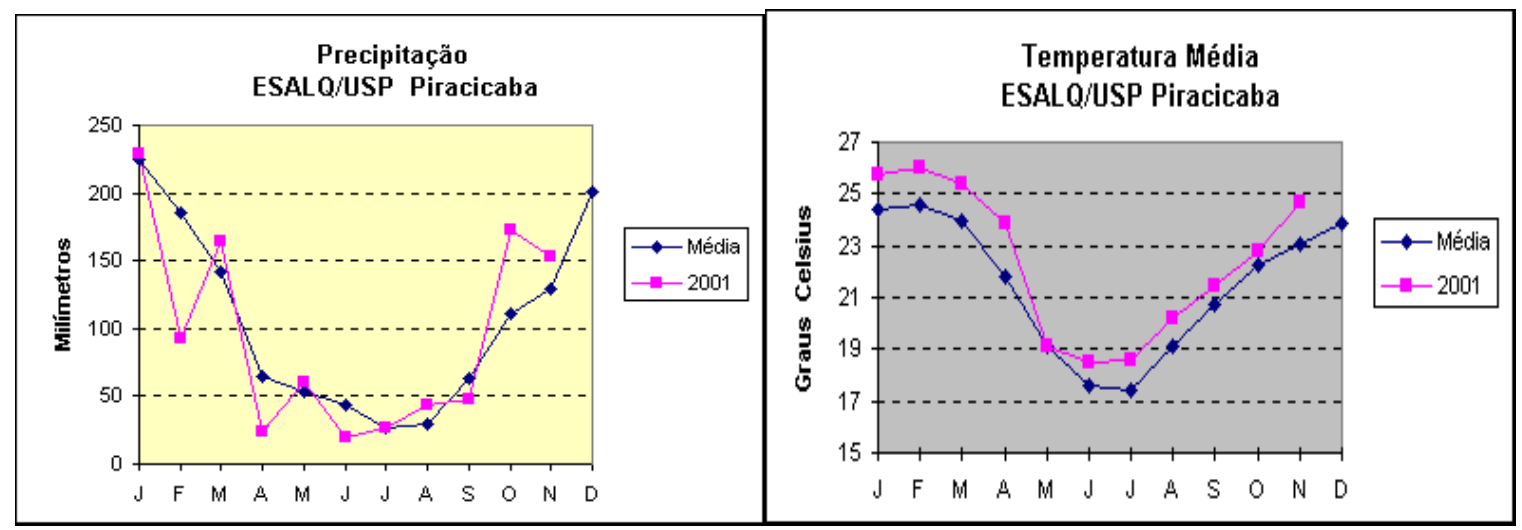

Figura 3 - Precipitação e temperatura média de Piracicaba 


\subsubsection{Solo}

No inicio desse ano experimental, foram aplicados calcário, fósforo e boro em algumas parcelas, como demonstrado na Tabela 8, objetivando alcançar uma saturação de bases igual a $80 \%$ e $30 \mathrm{mg} / \mathrm{dm}^{3}$ para fósforo.

Tabela 8. Adubação realizada em fevereiro de 2001

\begin{tabular}{ccccc}
\hline Bloco & Tratamento & $\begin{array}{c}\text { Calagem } \\
\text { t/ha }\end{array}$ & $\begin{array}{c}\text { Fosfatagem } \\
\text { kg SPS**/ha }\end{array}$ & $\begin{array}{c}\text { Boro } \\
\mathrm{kg} / \mathrm{ha}\end{array}$ \\
\hline 1 & 1 & 2.0 & - & 0.5 \\
1 & 2 & 2.2 & - & 0.5 \\
1 & 3 & 3.6 & 100 & 1 \\
2 & 1 & 4.0 & - & 0.5 \\
2 & 2 & 5.0 & - & 0.5 \\
2 & 3 & 3.3 & 300 & 0.5 \\
3 & 1 & 1.3 & - & 0.5 \\
3 & 2 & 2.7 & 400 & 1 \\
3 & 3 & 0.6 & - & 1 \\
4 & 1 & 2.1 & - & 0.5 \\
4 & 2 & 1.4 & 400 & 0.5 \\
4 & 3 & 1.9 & & 0.5 \\
\hline
\end{tabular}

* Calcário PRNT 65\%

** SPS $=$ Superfosfato simples.

\subsubsection{Instalação e condução do experimento}

Nesse ano, foi utilizada área de 3,2 ha, dividida em dois experimentos (irrigado e sequeiro) de 1,6 ha cada, divididos em 12 parcelas de 0,133 ha, o que permitiu um ciclo de pastejo de 36 dias com três dias de ocupação (Figura 4). 


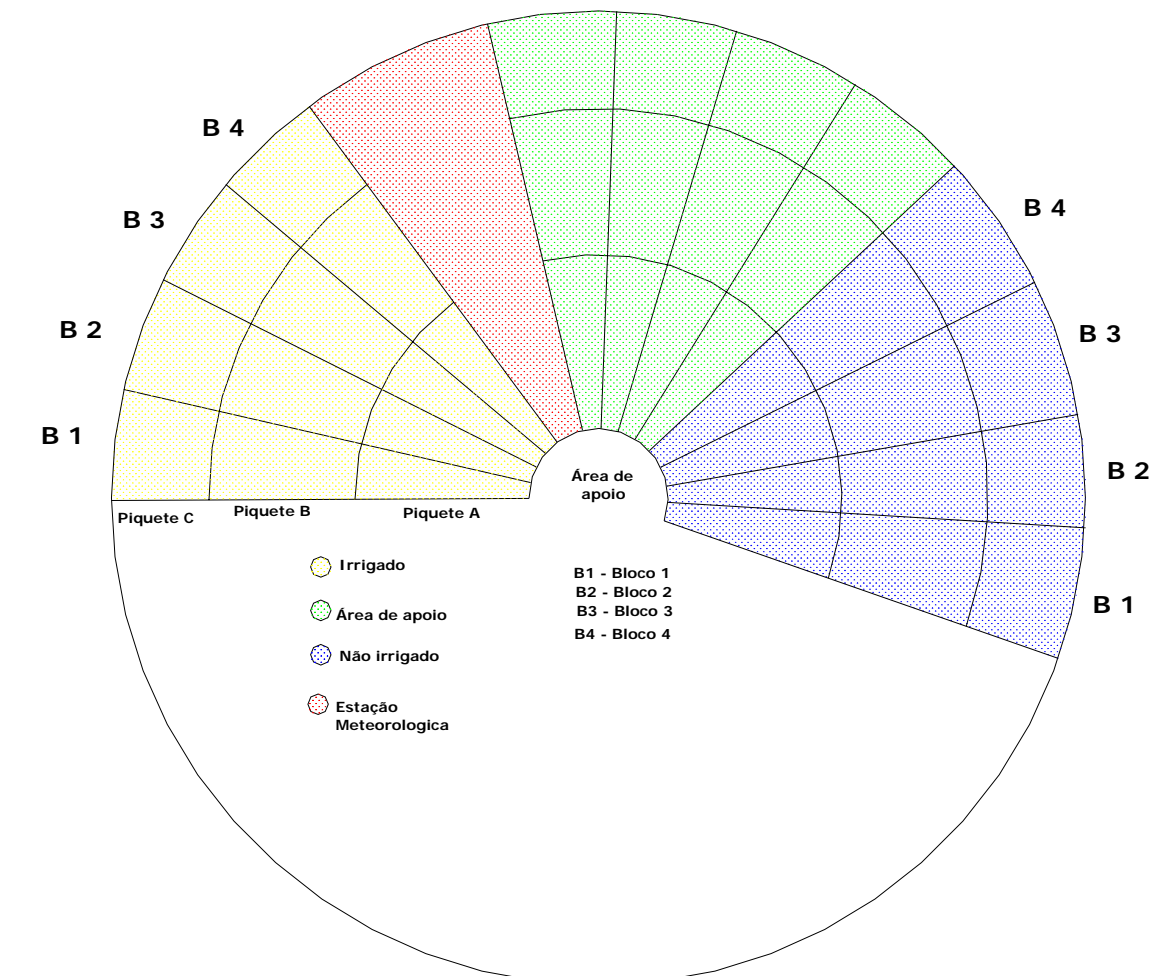

Figura 4 - Croqui da área experimental indicando as respectivas faixas dos experimentos

Os pastejos que caracterizaram o período experimental foram realizados entre 23 de fevereiro 2002 e 4 de janeiro de 2003, totalizando nove ciclos de pastejo. As adubações para produção da forragem foram parceladas e aplicadas logo após o pastejo, utilizando-se $275 \mathrm{~kg}$ da fórmula 26-03-00, 1\% de enxofre e $0,1 \%$ de boro, por hectare e por ciclo de pastejo, totalizando 430 e $357 \mathrm{~kg}$ de nitrogênio, 50 e $41 \mathrm{~kg} \mathrm{P}_{2} \mathrm{O}_{5}, 17$ e $14 \mathrm{~kg}$ de enxofre e 1,7 e 1,4 kg de boro para o experimento irrigado e sequeiro, respectivamente. A época de cada ciclo, bem como os ciclos onde foram efetuadas as adubações, pode ser observada na Tabela 9. 
Tabela 9. Distribuição dos ciclos de pastejo nos períodos com as respectivas épocas de ocorrência e os ciclos em que foram realizadas as adubações

\begin{tabular}{ccccc}
\hline \multirow{2}{*}{ Ciclo } & \multicolumn{2}{c}{ Época } & \multicolumn{2}{c}{ Adubação * } \\
& & & Irrigado & Sequeiro \\
\hline 1 & $23 / 02 / 02$ & $30 / 03 / 02$ & $X$ & $X$ \\
2 & $31 / 03 / 02$ & $06 / 05 / 02$ & $X$ & $X$ \\
3 & $07 / 05 / 02$ & $11 / 06 / 02$ & & \\
4 & $12 / 06 / 02$ & $17 / 07 / 02$ & & \\
5 & $18 / 07 / 02$ & $20 / 08 / 02$ & & \\
6 & $21 / 08 / 02$ & $26 / 09 / 02$ & $X$ & $X$ \\
7 & $27 / 09 / 02$ & $31 / 10 / 02$ & $X$ & $X$ \\
8 & $01 / 11 / 02$ & $07 / 12 / 02$ & $X$ & $X$ \\
9 & $08 / 12 / 02$ & $04 / 01 / 03$ & $X$ & \\
\hline
\end{tabular}

* Os ciclos marcados foram adubados com $275 \mathrm{~kg}$ da fórmula 26:03:00, 1\%S e 0,1\% de B.

A estimativa da massa de forragem pré-pastejo foi realizada conforme Penati et al. (2001). Essas avaliações foram efetuadas colhendo as plantas a 5 $\mathrm{cm}$ do solo, precedendo a entrada dos animais nos piquetes de amostragem, com as mesmas freqüência e metodologia do primeiro ano experimental. A massa de forragem pós-pastejo foi estimada ao término de cada ciclo de pastejo, com idênticas freqüência e metodologia utilizadas para determinar a massa de forragem pré-pastejo. A carga animal foi ajustada diariamente, em função dos níveis de massa de forragem pré e pós-pastejo, tendo como objetivo uma massa de forragem pós-pastejo de 2.500 a $3.000 \mathrm{~kg}$ de matéria seca verde/ha, conforme proposto por Penati (2002) e descrito por Maya (2003).

As amostras destinadas à avaliação do estado nutricional da planta foram retiradas das amostras para a determinação da massa de forragem prépastejo durante os nove ciclos. Foi feita a separação das partes da planta conforme descrito no primeiro ano experimental, incluindo-se lâmina de folhas 
senescentes (LFS) e colmo mais bainha senescentes (CBS). Foi considerado material senescido aquele que apresentava $50 \%$ de senescimento.

Após a separação, o material foi pesado e seco em estufa a $65^{\circ} \mathrm{C}$, a fim de determinar a porcentagem de cada componente da planta na base seca do material.

\subsection{Análise da terra e da planta}

A análise química da terra foi realizada no Laboratório de Solos do Departamento de Solos e Nutrição de Plantas da ESALQ-USP, com base em: matéria orgânica, pelo método colorimétrico (Quaggio \& Raij, 1979); pH em $\mathrm{CaCl}_{2}$ 0,01 $\mathrm{mol} \mathrm{L}^{-1}$ (Schofield \& Taylor, 1955; Davey \& Connyers, 1988); S-SO extraído com $\mathrm{CaCl}_{2}$ 0,15\% e determinado por turbidimetria de sulfato de bário (Vitti, 1989). O fósforo, o potássio, o cálcio e o magnésio foram extraídos com resina trocadora de íons. A determinação de cálcio e magnésio foi realizada por espectrofotometria de absorção atômica; de potássio, por fotometria de emissão atômica; e de fósforo, por espectrofotometria. O boro foi extraído com água quente e a determinação feita por espectrofotometria pelo método da azometina H (Abreu et al., 1994). As extrações de cobre, ferro, manganês e zinco foram efetuadas a partir do método DTPA (Lindsay \& Norvell, 1978) e as determinações, por espectrofotometria de absorção atômica.

As análises do tecido vegetal foram realizadas no Laboratório de Plantas do Departamento de Solos e Nutrição de Plantas da ESALQ-USP. Para o preparo dos extratos, procedeu-se a: digestão sulfúrica para determinação de nitrogênio; digestão nítrico-perclórica para determinação de fósforo, potássio, cálcio, magnésio, enxofre, cobre, ferro, manganês e zinco; e incineração para determinação de boro. A determinação do nitrogênio foi feita a partir do método Micro Kjeldahl. O fósforo foi determinado por colorimetria do metavanadato; o potássio, por fotometria de chama de emissão; cálcio, magnésio, cobre, ferro, 
manganês e zinco, por espectrofotometria de absorção atômica. A determinação de enxofre foi por turbidimetria do sulfato de bário, e a de boro, por colorimetria da azometina H (Sarruge \& Haag, 1974, Bataglia et al., 1983).

\subsection{DRIS}

\subsubsection{Métodos de cálculo do DRIS}

Os métodos para cálculo das funções das razões dos nutrientes, considerando uma relação entre o nutriente $X$ e $Y$ genérica, foram os seguintes:

Beaufils (1973):

$f(X / Y)=((X / Y) /(x / y)-1) * 100 K / C V$

se $X / Y>x / y$

e

$f(X / Y)=(1-(X / Y) /(x / y)) * 100 K / C V$

se $X / Y<x / y$

Elwali \& Gascho (1984):

$f(X / Y)=((X / Y) /(x / y)-1) * 100 K / C V$

se $X / Y>(X / y+s)$

e

$f(X / Y)=(1-(X / Y) /(x / y)) * 100 K / C V$

se $X / Y<(x / y-s)$

e 
$f(X / Y)=0$

se $x / y-s \leq X / Y \leq x / y+s$

Jones (1981):

$f(X / Y)=(X / Y-X / y) \cdot K / s$

Onde:

$\mathrm{X} / \mathrm{Y}=$ nutriente sob diagnóstico

$\mathrm{x} / \mathrm{y}=$ média da população de referência

CV = Coeficiente de variação na população de referência

$\mathrm{K}=$ constante de sensibilidade (neste estudo, foi utilizado $\mathrm{K}=5$ )

$\mathrm{s}=$ desvio-padrão da relação x/y na população de referência

A constante de sensibilidade ( $k$ ) é um componente das fórmulas para cálculo do DRIS pouco mencionado nos trabalhos envolvendo essa metodologia (Reis Júnior, 1999). A constante tem a finalidade de transformar os índices DRIS em números inteiros, e seu valor é arbitrário, variando, em geral, de 1 a 20 (Beaufils, 1973).

A razão entre um par de nutrientes pode ser tanto direta quanto inversa ( $X / Y$ ou $Y / X$, onde $X$ e $Y$ são concentrações de nutrientes). Foi utilizada, neste experimento, a ordem direta para todos os métodos propostos.

O índice DRIS para dado nutriente foi calculado da seguinte maneira (Beaufils, 1973):

$$
I x=\left\{\sum_{i=1}^{m_{i=1}} f\left(X_{i} / Y\right)-\sum_{j=1}^{n} f(Y / X j)\right\} /(m+n)
$$


Onde:

Ix = Índice DRIS para $X$

$X=$ nutriente a calcular o índice DRIS

$Y=$ nutriente

$\mathrm{m}=$ número de vezes cujo fator $\mathrm{X}$ encontra-se no numerador da razão da norma

$\mathrm{n}=$ número de vezes cujo fator $\mathrm{X}$ encontra-se no denominador da razão da norma

Foi calculado o índice de balanço nutricional (IBN), a partir da soma dos valores absolutos de todos os índices dos nutrientes, da seguinte forma (Beaufils, 1973):

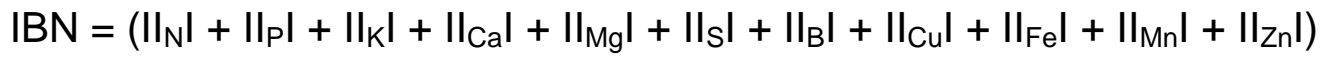

Do mesmo modo, foi calculado o IBN médio, sendo este a média dos valores absolutos de todos os índices dos nutrientes, como demonstrado abaixo:

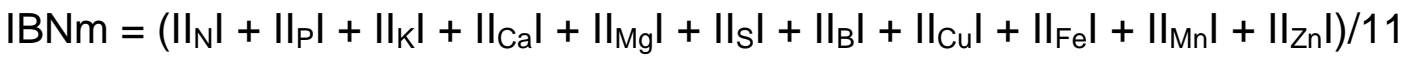

\subsubsection{Cálculo da norma}

As normas DRIS foram estabelecidas sob a seleção de uma população de dados coletados durante os dois anos experimentais com base nos dados de concentração dos nutrientes na LFRE e acúmulo de massa seca de capim Tanzânia manejado intensivamente em áreas irrigadas e de sequeiro em solo de elevada fertilidade, dando origem a uma população de referência (normas). 
Neste sentido, segundo Walworth \& Sumner (1987), o nível de corte para separar a população de referência da população não-referência deve ser escolhido de forma arbitrária. Por outro lado, Malavolta et al. (1997) recomendam que o ponto de referência seja $80 \%$ da produção máxima. Silveira et al. (2003), em estudo que determinou as normas DRIS para Brachiaria decumbens, utilizaram $50 \%$ da população máxima como ponto de referência para separação entre as duas subpopulações. Mourão Filho (2000) conclui que os critérios para a definição da subpopulação de referência precisam ser estudados e, de certa forma, ajustados especificamente, para cada situação. Sendo assim, segundo Beaufils (1973), não existe uma metodologia definida para determinar o nível de corte entre as subpopulações, sendo o mais importante a validade dos resultados finais obtidos.

Com base nos dados das taxas médias de acúmulo de massa seca prépastejo nos tratamentos (alta, média e baixa intensidade de pastejo) no primeiro e no segundo ano experimental (irrigado e sequeiro), determinou-se o critério de seleção. Nesse procedimento, tomou-se por pressuposto que as plantas com maiores taxas de crescimento apresentaram melhor balanço nutricional.

O nível de corte para a seleção da subpopulação de referência foi a média da taxa de acúmulo de massa seca. Desse modo, plantas que apresentaram acúmulo maior que a média anual foram selecionadas. Em virtude da diferença estatística entre as taxas de acúmulo de massa seca dos tratamentos realizados no primeiro ano experimental (Penati, 2002) e da nãoocorrência de diferença na concentração dos mineras nas LFRE (parte da planta escolhida para representar seu estado nutricional), determinaram-se bases diferentes para a seleção destinada a cada tratamento, sendo $2.298 \mathrm{~kg}$ $\mathrm{MS} / \mathrm{ha}, 3.350 \mathrm{~kg}$ de MS/ha e $3.104 \mathrm{~kg}$ de $\mathrm{MS} / \mathrm{ha}$, respectivamente para os tratamentos de alta, média e baixa intensidade de pastejo. Para os dados do segundo ano experimental (sequeiro e irrigado), a média das taxas de acúmulo foi $3.426 \mathrm{~kg}$ de MS/ha. Desse modo, dados referentes aos ciclos em que ocorreram limitações climáticas (período de inverno) foram eliminados, pois 
apresentavam acúmulos menores que a média anual. Assim, dos 177 dados iniciais de acúmulo de massa seca de forragem, 43 foram selecionados para compor a população de referência, apresentando uma taxa média de acúmulo de massa seca de $5.186 \mathrm{~kg}$ de MS/ha. Optou-se por selecionar os dados com taxas de acúmulo de MS acima da média, pois a população de dados iniciais já apresentava valores de taxa média de acúmulo de massa seca $(2.760 \mathrm{~kg}$ MS/ha) acima dos obtidos a campo e compatíveis ao valor observado por Tosi (1999), de 29,5 t MS/ha/ano, em capim Tanzânia adubado com 320 kg de N/ha/ano.

Para determinação da norma DRIS para capim Tanzânia, foram calculadas as médias, os coeficientes de variação e os desvios-padrão de todas as relações entre os nutrientes $\mathrm{N}, \mathrm{P}, \mathrm{K}, \mathrm{Ca}, \mathrm{Mg}, \mathrm{S}, \mathrm{Fe}, \mathrm{Mn}, \mathrm{Zn}, \mathrm{Cu}$ e B.

\subsubsection{Validação da norma DRIS}

Para a validação das normas, foram utilizados os dados obtidos por Belarmino (2001), que determinou o rendimento e qualidade da forragem de Panicum maximum Jacq. cv. Tanzânia em função da aplicação de superfosfato simples e sulfato de amônio. 


\section{RESULTADOS E DISCUSSÃO}

\subsection{Concentração dos minerais em diferentes partes do capim Tanzânia irrigado}

Não foi observado efeito significativo de interação entre intensidade de pastejo e período experimental, exceção feita para o cobre, ficando a significância, desta forma, limitada aos fatores isolados. Deste modo, serão apresentadas as concentrações médias para cada tratamento (intensidade de pastejo) e período experimental, nas diferentes partes analisadas da planta, tendo o período experimental apresentado diferenças mais evidentes entre as variáveis-respostas avaliadas.

As concentrações de nitrogênio nas diferentes partes das plantas manejadas em três intensidades (alta, média e baixa) de pastejo, referentes a massa de forragem pós-pastejo de 1.000, 2.500 e $4.000 \mathrm{~kg}$ de MSV/ha, ao longo do período experimental, são demonstradas na Tabela 10. As menores concentrações de nitrogênio nas partes analisadas foram observadas no período 01 , correspondente ao período de primavera e verão, enquanto as maiores ocorreram no período 03 , referente ao inverno. 
Tabela 10. Concentração de nitrogênio e fósforo nas partes da planta de capim Tanzânia irrigado em função dos períodos de coleta e das intensidades de pastejo

\begin{tabular}{lcccccc}
\hline \multirow{2}{*}{$\begin{array}{l}\text { Partes da } \\
\text { planta }\end{array}$} & \multicolumn{5}{c}{ Período de coleta } & \multicolumn{4}{c}{ Intensidade de pastejo } \\
& P1 & P2 & P3 & Alta & Média & Baixa \\
\hline FE & $17,6 \mathrm{~b}$ & $19,6 \mathrm{~b}$ & $25,9 \mathrm{a}$ & $22,1 \mathrm{~A}$ & $20,5 \mathrm{~A}$ & $20,4 \mathrm{~A}$ \\
LFRE & $17,7 \mathrm{c}$ & $20,8 \mathrm{~b}$ & $26,2 \mathrm{a}$ & $22,9 \mathrm{~A}$ & $21,0 \mathrm{~A}$ & $20,7 \mathrm{~A}$ \\
LFM & $15,6 \mathrm{c}$ & $18,3 \mathrm{~b}$ & $23,4 \mathrm{a}$ & $21,2 \mathrm{~A}$ & $18,6 \mathrm{~A}$ & $17,4 \mathrm{~B}$ \\
CB & $8,8 \mathrm{~b}$ & $8,6 \mathrm{~b}$ & $12,9 \mathrm{a}$ & $11,3 \mathrm{~A}$ & $9,5 \mathrm{~A}$ & $9,5 \mathrm{~A}$ \\
PT & $14,2 \mathrm{~b}$ & $13,4 \mathrm{~b}$ & $19,8 \mathrm{a}$ & $17,5 \mathrm{~A}$ & $15,1 \mathrm{~B}$ & $14,8 \mathrm{~B}$ \\
& ------------------ Fósforo $(\mathrm{g} / \mathrm{kg} \mathrm{MS})^{\star}$ & & & \\
& $2,5 \mathrm{~b}$ & $3,4 \mathrm{a}$ & $3,6 \mathrm{a}$ & $3,3 \mathrm{~A}$ & $3,2 \mathrm{~A}$ & $3,0 \mathrm{~A}$ \\
FE & $2,0 \mathrm{~b}$ & $3,0 \mathrm{a}$ & $3,0 \mathrm{a}$ & $2,8 \mathrm{~A}$ & $2,7 \mathrm{~A}$ & $2,5 \mathrm{~A}$ \\
LFRE & $1,6 \mathrm{~b}$ & $2,4 \mathrm{a}$ & $2,4 \mathrm{a}$ & $2,3 \mathrm{~A}$ & $2,2 \mathrm{AB}$ & $1,9 \mathrm{~B}$ \\
LFM & $1,9 \mathrm{~b}$ & $2,4 \mathrm{a}$ & $2,3 \mathrm{a}$ & $2,4 \mathrm{~A}$ & $2,2 \mathrm{~A}$ & $1,9 \mathrm{~A}$ \\
CB & $2,0 \mathrm{~b}$ & $2,5 \mathrm{a}$ & $2,7 \mathrm{a}$ & $2,6 \mathrm{~A}$ & $2,4 \mathrm{~A}$ & $2,2 \mathrm{~A}$ \\
PT &
\end{tabular}

FE - Folha em expansão; LFRE - Lâmina de folha recém-expandida; LFM - Lâmina de folha madura; CB - Colmo mais bainha; $\mathrm{PT}$ - Planta toda.

P1 - 30/10/1999 a 14/02/2000; P2 - 15/02/2000 a 01/06/2000; P3 - 02/06/2000 a 23/10/2000.

Intensidade de pastejo alta, média e baixa - 1.000, 2.500 e $4.000 \mathrm{~kg} \mathrm{MSV/ha,} \mathrm{respectivamente,} \mathrm{de} \mathrm{resíduo} \mathrm{pós-pastejo.}$

* Médias seguidas pela mesma letra na linha (minúscula para período de coleta e maiúscula para tratamento) não são diferentes ( $p>0.05)$ pelo teste de Tukey.

Sória (2002) estudou o efeito da aplicação de diferentes lâminas de água $(0,30,70,100$ e 150\% da capacidade de campo) e da adubação nitrogenada $(0,100,275,756$ e $2.079 \mathrm{~kg}$ de N/ha/ano) e suas interações, realizando nove cortes entre novembro de 2000 e novembro de 2001. As médias das produções nas diferentes lâminas de irrigação, na dose de $756 \mathrm{~kg}$ de N/ha/ano, foram $3.938 \mathrm{~kg} / \mathrm{ha}$ de MS para o corte 1 (21/11/00 a 01/01/01), $736 \mathrm{~kg} / \mathrm{ha}$ de MS para o corte $6(20 / 07$ a 26/08/01) e $3.161 \mathrm{~kg} / \mathrm{ha}$ de MS para o corte $9(10 / 10 \mathrm{a}$ 14/11/01). As concentrações de nitrogênio nas folhas, na dose de $756 \mathrm{~kg}$ de $\mathrm{N} / \mathrm{ha} / \mathrm{ano}$, foram, respectivamente para os cortes 1,6 e $9,17,3,28,7$ e $18,5 \mathrm{~g} / \mathrm{kg}$ 
MS. Observou-se aumento da concentração de nitrogênio no corte 6 (período de inverno), concomitantemente com a redução da produção de massa seca e o retorno da concentração de nitrogênio aos valores de 18,5 g/ $/ \mathrm{kg}$ MS no corte 9 (período de primavera), quando as condições climáticas são favoráveis para maior acúmulo de massa seca.

Deste modo, pode-se concluir que o aumento da concentração de nitrogênio nesse experimento, no período 03 , pode estar relacionado à diminuição da taxa média de acúmulo de massa seca, decorrente de limitações climáticas, principalmente temperatura e luminosidade (período de inverno) (Tabela 1), quando a taxa expressa em $\mathrm{kg} \mathrm{MS/ha/ciclo} \mathrm{passou} \mathrm{de} 3.891$ (média dos três tratamentos), no período 02 , para 221, no período 03, como determinou Penati (2002) na área experimental dessa pesquisa.

Faquin et al. (1994) também obtiveram maiores concentrações de nitrogênio na planta toda nos tratamentos que limitaram o crescimento, ou seja, $41 \mathrm{~g} / \mathrm{kg} \mathrm{MS}$ no tratamento sem fósforo e $20 \mathrm{~g} / \mathrm{kg}$ MS no tratamento completo, fato este atribuído ao efeito da concentração do nutriente no tecido vegetal.

Este aspecto fica evidente ao observar a Tabela 11, onde são apresentadas as concentrações de nitrato $\left(\mathrm{N}^{\left.-\mathrm{NH}_{3}\right)}\right.$ em função dos períodos de coleta. Observa-se que, em todas as partes analisadas, as concentrações de nitrato são maiores no período 03 (1,7 a 4,9 g/kg MS) em relação aos períodos 01 e 02 ( 0,4 a $1,5 \mathrm{~g} / \mathrm{kg} \mathrm{MS})$. 
Tabela 11. Concentração de nitrogênio na forma nítrica nas partes da planta de capim Tanzânia irrigado em função dos períodos de coleta

\begin{tabular}{|c|c|c|c|}
\hline \multirow{3}{*}{$\begin{array}{c}\text { Partes } \\
\text { da } \\
\text { planta }\end{array}$} & \multicolumn{3}{|c|}{$\mathrm{N}-\mathrm{NO}_{3}(\mathrm{~g} / \mathrm{kg} \mathrm{MS})^{\star}$} \\
\hline & \multicolumn{3}{|c|}{ Período de coleta } \\
\hline & P1 & P2 & P3 \\
\hline FE & $0,4 \mathrm{~b}$ & $0,5 \mathrm{~b}$ & $1,7 \mathrm{a}$ \\
\hline LFRE & $0,4 \mathrm{~b}$ & $0,7 \mathrm{~b}$ & $1,8 \mathrm{a}$ \\
\hline LFM & $0,5 \mathrm{~b}$ & $0,7 \mathrm{~b}$ & $2,0 \mathrm{a}$ \\
\hline CB & $0,6 \mathrm{~b}$ & $1,5 \mathrm{~b}$ & $4,9 a$ \\
\hline
\end{tabular}

FE - Folha em expansão; LFRE - Lâmina de folha recém-expandida; LFM - Lâmina de folha madura; CB - Colmo mais bainha.

P1 - 30/10/1999 a 14/02/2000; P2 - 15/02/2000 a 01/06/2000; P3 - 02/06/2000 a 23/10/2000.

Intensidade de pastejo alta, média e baixa - 1.000, 2.500 e 4.000 kg MSV/ha, respectivamente, de resíduo pós-pastejo.

* Médias seguidas pela mesma letra na linha não são diferentes ( $p>0.05)$ pelo teste de Tukey.

O íon nitrato, após a absorção, pode ser estocado nos vacúolos do sistema radicular (Corrêa, 1996) ou ser translocado via xilema para a parte aérea, onde pode ser armazenado ou reduzido (Abreu, 1999). O nitrogênio que excede a necessidade de crescimento das plantas geralmente é acumulado no vacúolo na forma de nitrato. Este, se não for prontamente assimilado, forma o que se denomina "pool substrato". No trabalho de Primavesi et al. (2001), houve acúmulo significativo de nitrato nas plantas tratadas com $200 \mathrm{~kg} / \mathrm{ha}$ de N por corte, na forma de nitrato de amônio, sendo este $0,72 \mathrm{~g} / \mathrm{kg} \mathrm{MS}$ de $\mathrm{N}_{-} \mathrm{NO}_{3}$ na média dos cinco cortes realizados. Deste modo, verifica-se que os valores de nitrato observados na Tabela 11 (4,9 mg/kg MS) são maiores que os determinados por Primavesi et al. (2001). Assim, possivelmente tenha ocorrido acúmulo significativo de nitrato nas plantas no período 03 , demonstrando que o nitrogênio absorvido excedeu a capacidade da planta forrageira de assimilá-lo.

Ribeiro et al. (1999) trabalharam com cinco doses de nitrogênio em capim Elefante (0, 25, 50, 75 e $100 \mathrm{~kg}$ de N/ha/ciclo), pastejado ao atingir 80 e $120 \mathrm{~cm}$, no período de outubro a junho de 1994, no ano de formação da pastagem. Nesse trabalho, houve aumento das concentrações de nitrogênio 
nas lâminas com o suceder dos cortes, sendo 15,8 g/kg MS no primeiro e 18,7 $\mathrm{g} / \mathrm{kg}$ MS no terceiro corte. Esse comportamento foi interpretado como sendo o efeito residual do adubo nitrogenado, concomitantemente com a queda do rendimento forrageiro em decorrência de fatores climáticos.

Por outro lado, Ambrosano et al. (1996) estudaram o comportamento do nitrogênio $\left({ }^{15} \mathrm{~N}\right)$ no capim Tobiatã em sucessivos cortes. Os autores observaram que, com o avançar do período de coleta, o capim utilizava menor porcentagem do nitrogênio proveniente do fertilizante sem comprometer a produção de massa seca, demonstrando menor dependência da planta em relação ao fertilizante aplicado durante o ciclo de crescimento. Neste sentido, a matéria orgânica do solo pode ser um bom indicador de sua capacidade para suprir nitrogênio. Este experimento foi conduzido em área recém-estabelecida, com teores inicias de matéria orgânica de $25 \mathrm{~g} / \mathrm{dm}^{3}$ e, no final do período experimental, esses valores eram 30,8 g/ $\mathrm{dm}^{3}$ (Tabela 2 e 3), demonstrando uma sensível melhora neste parâmetro. Deste modo, espera-se que, com o decorrer do período experimental e das adubações nitrogenadas, as concentrações de nitrogênio na plantas sejam mais equilibradas, pois o sistema tem melhores condições de fornecer esse nutriente às plantas, seja pelo acúmulo residual das adubações (Ribeiro et al., 1999), pela disponibilidade do $\mathrm{N}$ mineralizado pelo solo (Ambrosano et al., 1996) ou pela concentração de nutrientes devido às condições desfavoráveis de crescimento (Sória, 2002).

Pagoto (2001) demonstrou ocorrer aumento do sistema radicular da planta forrageira no decorrer do período experimental, possibilitando maior exploração do solo, facilitando a absorção de nutrientes. Assim, podem-se esperar aumentos em produção de massa seca e, conseqüentemente, em produtividade (kg PV/ha), decorrentes de adubações sucessivas, em virtude de a planta forrageira estar mais bem-estruturada para responder à melhora da fertilidade do solo.

Ribeiro et al. (1999) obtiveram menores concentrações de nitrogênio nos colmos mais bainha no último corte (6,8 $\mathrm{g} / \mathrm{kg} \mathrm{MS})$, quando comparados aos do 
primeiro (11,68 g/kg MS), devido à intensificação do alongamento dos colmos e, conseqüentemente, à diluição do conteúdo celular. Observa-se, na Tabela 10, que as concentrações de nitrogênio nos CB aumentaram apenas no período 03. O período 02 apresentou maior porcentagem de perfilhos em estado reprodutivo (Santos, 2002), o que justificaria a manutenção das concentrações de nitrogênio no segundo corte, devido a um efeito semelhante ao demonstrado por Ribeiro et al. (1999).

O fósforo teve comportamento semelhante ao do nitrogênio (Tabela 10). No entanto, o aumento da concentração ocorreu em todas as partes analisadas a cada período, não havendo diferenças entre os períodos 02 e 03, mantendose entre 2,3 e 3,6 g/kg MS no período 03.

Estes resultados são contrários aos encontrados por Cecato et al. (2001) manejando capim Tanzânia com lotação contínua e a alturas de 20, 40, 60 e 80 cm. Nesse experimento, as concentrações de fósforo nas lâminas foliares decresceram ao longo do período experimental compreendido entre janeiro e maio. Almeida et al. (2000), trabalhando com capim Elefante, obtiveram a mesma tendência, tendo as concentrações de fósforo decrescido no decorrer do período experimental, de outubro a abril. Em ambos experimentos, as concentrações de fósforo variaram de 3,5 a 3,8 g/kg MS nos colmos e 4,2 a 4,9 $\mathrm{g} / \mathrm{kg}$ MS nas lâminas foliares. Observa-se que, mesmo nas menores concentrações de fósforo no final do período experimental, essas são maiores que as determinadas neste experimento (Tabela 10) e acima do nível crítico estabelecido por Corrêa (1996) como sendo 2,3 g/kg MS na parte aérea de capim Tanzânia. As comparações dos resultados deste experimento com os de Almeida et al. (2000) e Cecato et al. (2001) estariam prejudicadas porque as plantas apontam consumo de luxo, como se deduz do trabalho de Corrêa (1991). Este, em trabalho com doses de fósforo cultivando Panicum maximum Jack, demonstrou que a inflexão da curva de produção - $18 \mathrm{~g}$ de MS/vaso ocorreu na dose de $1.760 \mathrm{~kg}$ de $\mathrm{P}_{2} \mathrm{O}_{5} /$ ha e a inflexão da curva de concentração de fósforo - 2,9 $\mathrm{g} / \mathrm{kg} \mathrm{MS} \mathrm{-,} \mathrm{na} \mathrm{dose} \mathrm{de} 2.680 \mathrm{~kg} \mathrm{P}_{2} \mathrm{O}_{5} / \mathrm{ha}$, demonstrando a 
capacidade da planta de continuar acumulando fósforo mesmo após ter atingido a máxima produção de massa nas condições impostas no experimento.

O aumento da concentração de fósforo na planta deste trabalho pode ser atribuído à melhora da condição de fertilidade do solo, decorrente das adubações realizadas, totalizando $134 \mathrm{~kg}$ de $\mathrm{P}_{2} \mathrm{O}_{5} / \mathrm{ha} / \mathrm{ano}$, o que possibilitou a elevação do teor no solo de 19 para $30 \mathrm{mg} / \mathrm{dm}^{3}$ (média dos tratamentos) (Tabela 2 e 3), quando o nível crítico externo determinado por Corrêa et al. (1996) para capim Tanzânia é $21 \mathrm{mg} / \mathrm{dm}^{3}$.

Com relação às exigências nutricionais da forrageira a esses nutrientes, os valores encontrados de nitrogênio variaram de 17,7 a 26,2 $\mathrm{g} / \mathrm{kg}$ MS na LFRE. Estes estão próximos do nível crítico de 21,4 g/kg MS, determinado por Abreu (1999) na folha nova de capim Tanzânia aos 28 dias de crescimento. Valores similares foram encontrados por Colozza (1998) (20,8 e 22,9 g/kg MS) em folhas novas de capim Mombaça, no primeiro e segundo cortes, respectivamente. Hoffman et al. (1995) também obtiveram 19,4 g/kg MS na folha nova de capim Colonião aos 46 dias de crescimento. Nos três experimentos apontados, os níveis críticos foram estabelecidos para 90\% da produção máxima e a parte analisada foi a mesma utilizada neste experimento, a LFRE.

Para o fósforo as concentrações da PT (2,0 a 2,7 g/kg MS) estão acima do nível crítico de 1,9 g/kg MS, determinado por Dias Filho (1995) na parte aérea de capim Tanzânia. Esse valor está próximo do encontrado por Corrêa et al. (1996) 2,3 g/kg MS na parte aérea do mesmo cultivar. Rossi (1999) determinou os níveis críticos para diferentes partes do capim Colonião, sendo 2,3 $\mathrm{g} / \mathrm{kg}$ MS para folhas em expansão, 1,6 $\mathrm{g} / \mathrm{kg}$ MS para lâminas de folhas recém-expandidas e 1,5 $\mathrm{g} / \mathrm{kg}$ MS para lâminas de folhas maduras. Os valores encontrados neste experimento variam de 2,5 a 3,6 g/kg MS para FE, 2,0 a 3,0 $\mathrm{g} / \mathrm{kg}$ MS para LFRE, e de 1,6 a $2,4 \mathrm{~g} / \mathrm{kg}$ MS para LFM (Tabela 10), demonstrando a boa condição nutricional da forrageira comparada à determinada por Rossi (1999). 
Os resultados da Tabela 10 indicam pouco efeito dos tratamentos nas concentrações dos minerais nos componentes analisados, ocorrendo diferenças significativas apenas no tratamento de baixa intensidade em relação à LFM, onde a concentração de nitrogênio foi menor (17,4 g/kg MS), e no tratamento de alta intensidade na PT (17,5 g/kg MS), sendo maior que nos outros tratamentos.

Não houve diferenças na concentração de fósforo entre os tratamentos, exceto para LFM nas intensidades baixa e alta. A concentração desse nutriente na intensidade baixa de pastejo foi menor $(1,9 \mathrm{~g} / \mathrm{kg} \mathrm{MS})$ em relação à intensidade alta (2,3 $\mathrm{g} / \mathrm{kg} \mathrm{MS})$, mas o tratamento de média intensidade não diferiu dos demais, mantendo concentração de 2,2 g/kg MS.

As menores concentrações de nitrogênio e fósforo nas LFM no pastejo menos intenso podem estar relacionadas à maior quantidade de material senescente, como determinado por Penati (2002) na mesma área experimental, onde esse tratamento obteve a menor eficiência de pastejo (47\%) em comparação ao de maior intensidade (75\%). Malavolta et al. (1997) demonstraram que ocorre diminuição das concentrações de nitrogênio, fósforo e potássio com o avançar da idade do tecido vegetal em cana-de-açúcar, milho e sorgo. As menores concentrações de fósforo e nitrogênio em material senescente são atribuídas à elevada mobilidade desses nutrientes na planta.

A Tabela 12 indica os resultados referentes às concentrações de potássio e cálcio em função dos períodos de coleta e das intensidades de pastejo nas partes da planta de capim Tanzânia irrigado.

A concentração de potássio variou entre os períodos experimentais, nas FE, LFRE, CB e PT, sendo os menores valores encontrados no período 02. Os períodos 01 e 03 apresentaram valores maiores em relação ao período 02 e não diferiram entre si nas concentrações de potássio nas LFRE e PT. Além disso, o potássio foi o nutriente que apresentou as maiores concentrações nas partes analisadas, bem como na planta toda de capim Tanzânia, atingindo valores de 51,2 g/kg MS nos CB e 37,2 g/kg MS na PT. 
Tabela 12. Concentração de potássio e cálcio nas partes da planta de capim Tanzânia irrigado em função dos períodos de coleta e das intensidades de pastejo

\begin{tabular}{lcccccc}
\hline \multirow{2}{*}{$\begin{array}{l}\text { Partes da } \\
\text { planta }\end{array}$} & \multicolumn{5}{c}{ Período de coleta } & \multicolumn{3}{c}{ Intensidade de pastejo } \\
& P1 & P2 & P3 & Alta & Média & Baixa \\
\hline FE & $30,1 \mathrm{~b}$ & $27,8 \mathrm{c}$ & $33,1 \mathrm{a}$ & $31,0 \mathrm{~A}$ & $30,1 \mathrm{~A}$ & $30,0 \mathrm{~A}$ \\
LFRE & $27,3 \mathrm{a}$ & $24,6 \mathrm{~b}$ & $28,8 \mathrm{a}$ & $27,1 \mathrm{~A}$ & $26,6 \mathrm{~A}$ & $26,9 \mathrm{~A}$ \\
LFM & $27,2 \mathrm{a}$ & $24,9 \mathrm{a}$ & $25,8 \mathrm{a}$ & $26,6 \mathrm{~A}$ & $25,3 \mathrm{~A}$ & $26,0 \mathrm{~A}$ \\
CB & $51,2 \mathrm{a}$ & $40,4 \mathrm{c}$ & $46,5 \mathrm{~b}$ & $51,0 \mathrm{~A}$ & $43,7 \mathrm{~B}$ & $43,4 \mathrm{~B}$ \\
PT & $37,2 \mathrm{a}$ & $32,5 \mathrm{~b}$ & $36,0 \mathrm{a}$ & $36,9 \mathrm{~A}$ & $34,3 \mathrm{~A}$ & $34,6 \mathrm{~A}$ \\
& ----------------------- Cálcio $(\mathrm{g} / \mathrm{kg} \mathrm{MS})^{\star}---------------------$ \\
FE & $1,5 \mathrm{a}$ & $1,7 \mathrm{a}$ & $1,7 \mathrm{a}$ & $1,4 \mathrm{~A}$ & $1,7 \mathrm{~A}$ & $1,7 \mathrm{~A}$ \\
LFRE & $4,2 \mathrm{~b}$ & $5,6 \mathrm{a}$ & $4,7 \mathrm{~b}$ & $4,7 \mathrm{~A}$ & $4,9 \mathrm{~A}$ & $4,8 \mathrm{~A}$ \\
LFM & $6,5 \mathrm{~b}$ & $7,4 \mathrm{a}$ & $6,1 \mathrm{~b}$ & $6,9 \mathrm{~A}$ & $6,8 \mathrm{~A}$ & $6,3 \mathrm{~A}$ \\
CB & $1,4 \mathrm{a}$ & $1,2 \mathrm{~b}$ & $1,3 \mathrm{~b}$ & $1,3 \mathrm{~A}$ & $1,3 \mathrm{~A}$ & $1,1 \mathrm{~A}$ \\
PT & $3,0 \mathrm{a}$ & $3,0 \mathrm{a}$ & $2,9 \mathrm{a}$ & $3,1 \mathrm{~A}$ & $3,0 \mathrm{~A}$ & $2,8 \mathrm{~A}$ \\
\hline
\end{tabular}

FE - Folha em expansão; LFRE - Lâmina de folha recém-expandida; LFM - Lâmina de folha madura; CB - Colmo mais bainha; PT - Planta toda.

P1 - 30/10/1999 a 14/02/2000; P2 - 15/02/2000 a 01/06/2000; P3 - 02/06/2000 a 23/10/2000.

Intensidade de pastejo alta, média e baixa - 1.000, 2.500 e $4.000 \mathrm{~kg}$ MSV/ha, respectivamente, de resíduo pós-pastejo.

* Médias seguidas pela mesma letra na linha (minúscula para período de coleta e maiúscula para tratamento) não são diferentes $(p>0.05)$ pelo teste de Tukey.

No período 02, o acúmulo de massa seca foi $3.891 \mathrm{~kg}$ de $\mathrm{MS} / \mathrm{ha} / \mathrm{ciclo}$, sendo acompanhado pela maior participação de colmos mais bainha (CB). A contribuição dos CB foi 37,5, 54,3 e 44,3\% na produção total de massa seca, nos períodos 01, 02 e 03, respectivamente (Tabela 13). A maior participação dos $\mathrm{CB}$ e as altas concentrações de potássio poderiam levar a um maior requerimento de potássio no período 02 , visto que os $C B$ apresentaram as maiores concentrações desse elemento (40,4 a 51,2 g/kg MS), podendo determinar redução das concentrações nesse período (Tabela 12). Pereira (2001) também observou variações nas concentrações de potássio nos CB 
(39,2 e $31,8 \mathrm{~g} / \mathrm{kg} \mathrm{MS}$ no $1^{\circ}$. e no $2^{\circ}$. corte, respectivamente) e nas LFM (26,9 e $27,9 \mathrm{~g} / \mathrm{kg} \mathrm{MS}$ no $1^{\circ}$. e no $2^{\circ}$. corte, respectivamente), como ocorrido neste experimento, com valores de 40,4 a 51,2 g/kg MS nos CB e 24,9 a 27,2 g/kg MS nas LFM (Tabela 12).

Tabela 13. Participação percentual das partes da planta de capim Tanzânia irrigado na produção de massa seca em função dos tratamentos e períodos de coleta

\begin{tabular}{lcccccc}
\hline \multirow{2}{*}{$\begin{array}{c}\text { Partes da } \\
\text { planta }\end{array}$} & \multicolumn{5}{c}{ Período de coleta } & \multicolumn{3}{c}{ Porcentagem (\%) } \\
& P1 & P2 & P3 & Alta & Média & Baixa \\
\hline FE & $16,1 \mathrm{a}$ & $8,2 \mathrm{C}$ & $11,8 \mathrm{~b}$ & $13,0 \mathrm{~A}$ & $11,8 \mathrm{~A}$ & $12,0 \mathrm{~A}$ \\
LFRE & $36,9 \mathrm{a}$ & $23,0 \mathrm{c}$ & $31,7 \mathrm{~b}$ & $32,8 \mathrm{~A}$ & $29,6 \mathrm{~A}$ & $29,2 \mathrm{~A}$ \\
LFM & $10,0 \mathrm{~b}$ & $13,6 \mathrm{a}$ & $12,2 \mathrm{ab}$ & $11,8 \mathrm{~A}$ & $12,3 \mathrm{~A}$ & $11,8 \mathrm{~A}$ \\
CB & $37,5 \mathrm{C}$ & $54,3 \mathrm{a}$ & $44,3 \mathrm{~b}$ & $42,4 \mathrm{~A}$ & $46,6 \mathrm{AB}$ & $47,3 \mathrm{~B}$ \\
\hline
\end{tabular}

FE - Folha em expansão; LFRE - Lâmina de folha recém-expandida; LFM - Lâmina de folha madura; CB - Colmo mais bainha.

P1 - 30/10/1999 a 14/02/2000; P2 - 15/02/2000 a 01/06/2000; P3 - 02/06/2000 a 23/10/2000.

Intensidade de pastejo alta, média e baixa - 1.000, 2.500 e $4.000 \mathrm{~kg} \mathrm{MSV/ha,} \mathrm{respectivamente,} \mathrm{de} \mathrm{resíduo} \mathrm{pós-pastejo.}$

* Médias seguidas pela mesma letra na linha (minúscula para período de coleta e maiúscula para tratamento) não são

diferentes ( $p>0.05)$ pelo teste de Tukey.

As concentrações de cálcio nas LFRE e LFM demonstraram um comportamento sazonal, mas diferentes das de potássio, ocorrendo aumento das concentrações no período 02, com posterior queda no período 03 (Tabela 12). Para PT, FE e CB, esse comportamento não foi observado. No entanto, segundo Colozza (1998), Abreu (1999) e Pereira (2001), a LFRE é a parte da planta que mais representam o estado nutricional da forrageira.

Diversos fatores, externos e/ou internos, modificam a velocidade de absorção dos íons pela planta, sendo a presença de outro íon um desses fatores. Um exemplo de efeitos interiônicos relaciona o cálcio e o magnésio com o potássio, este tem efeito negativo na absorção dos primeiros por inibição competitiva, ou seja, o inibidor (potássio) combina-se com o mesmo sítio ativo 
do carregador, diminuindo a absorção de cálcio e magnésio (Malavolta et al., 1997). Esses autores citam que, em trabalho realizado com sorgo sacarino cv. Brandes, a concentração de cálcio nas lâminas foliares diminuiu de 20 para 5 $\mathrm{g} / \mathrm{kg} \mathrm{MS}$, quando a concentração de potássio passou de 5 para $30 \mathrm{~g} / \mathrm{kg} \mathrm{MS}$, demonstrando o efeito inibidor do potássio sobre o cálcio. Neste aspecto, Gomide (1986) sugere que aplicações maciças de potássio devem ser evitadas para prevenir a absorção de luxo e minimizar a interferência na absorção de magnésio e cálcio pela planta.

Esse efeito interativo pode ter gerado deficiência de cálcio na planta, visto que as concentrações de cálcio na PT (2,8 a 3,1 g/kg MS) estão abaixo das encontradas por Faquin et al. (1994), em seu tratamento completo (5 g/kg MS). Do mesmo modo, Werner et al. (1979) demonstraram que as concentrações de cálcio na parte aérea variaram entre 3,5 g/kg MS e 4,2 g/kg MS, respectivamente, nos tratamentos sem e com o uso de calagem. Também, Faquin et al. (1997) determinaram as concentrações de cálcio na parte aérea de Brachiaria brizantha e Andropogom gayanus, obtendo valores de, respectivamente, 4,9 a 5,5 e 4,7 a 5,3 g/kg MS para essas espécies.

As concentrações na FE - 1,5 a 1,7 g/kg MS - (Tabela 12) estão bem abaixo dos valores apresentados por Faquin et al. (1997) e Werner et al. (1979). A amplitude de variação das concentrações da FE (1,5 a 1,7 g/kg MS) em relação às verificadas nas LFM (6,1 a 7,4 g/kg MS) demonstra concentração de cálcio nos tecidos mais velhos, devido a sua baixa mobilidade na planta.

De maneira contrária, as concentrações de potássio na LFRE $(24,57$ a 28,83 g/kg MS) estão acima do nível crítico indicado por Pereia (2001), de 17,3 $\mathrm{g} / \mathrm{kg}$ MS na LFRE do capim Mombaça aos 22 dias de crescimento, demonstrando um consumo de luxo pela planta forrageira. Andrade et al. (2000) sugerem nível critico de potássio de 20,0 g/kg MS nas folhas de capim Elefante e $21,3 \mathrm{~g} / \mathrm{kg}$ MS para os colmos aos 54 dias de crescimento. Os valores encontrados por Lavres Júnior (2001), usando elevadas doses de adubações com potássio (429 mg K/l), também foram mais baixos (18,8 g/kg MS na LFRE) 
que os obtidos neste trabalho, acontecendo o mesmo para a fração CB, quando atingiu 33,2 g/kg MS, e para FE (19,5 g/kg MS) no primeiro corte do capim Mombaça. Os valores observados para a concentração do potássio (Tabela 12) na LFER e no CB variaram de 24,6 a 28,8 e 40,4 a 51,2 g/kg MS, respectivamente, indicando que os elevados níveis apresentados poderiam justificar o efeito antagônico na absorção de cálcio.

Os teores de cálcio, magnésio e potássio no solo em que se realizou este experimento foram, na média dos tratamentos, 39, 19 e 6,6 mmol $/ \mathrm{dm}^{3}$ ao final do experimento, respectivamente para cálcio, magnésio e potássio (Tabela 2 e 3). Por outro lado, apresentaram na CTC uma relação de 39, 20 e 6,7\% da CTC para cálcio, magnésio e potássio, respectivamente, ao final do experimento. Deste modo, pode-se observar que, em teores absolutos, os três nutrientes se encontraram acima dos níveis críticos externos determinados por Raij et al. (1997). Esses autores definiram limites de interpretação para os teores de cálcio, magnésio e potássio no solo, sendo baixo, médio e alto. Para $\mathrm{Ca}$, esses valores são 0 a 3,4 a 7 e maior que $7 \mathrm{mmol}_{\mathrm{c}} / \mathrm{dm}^{3}$, respectivamente; para $\mathrm{Mg}, 0$ a 4,5 a 8 e maior que $8 \mathrm{mmol}_{\mathrm{c}} / \mathrm{dm}^{3}$; para $\mathrm{K}, 0$ a 1,5, 1,6 a 3,0 e 3,1 a 6,0. No entanto, em termos relativos, existe uma divergência dos valores propostos por Corsi \& Nussio (1994), de 65 a 85\%, 6 a 12\% e 2 a 5\%, respectivamente para $\mathrm{Ca}, \mathrm{Mg}$ e K na CTC (capacidade de troca catiônica), o que poderia gerar problemas de equilíbrio nutricional na planta, como discutido anteriormente. Do mesmo modo, Vitti (1997) recomenda que a participação de Ca, Mg e K na CTC seja 5, 16 e 48\% para saturação de bases de 70\%.

Neste sentido, Corsi \& Martha Júnior (1999) alertam que, ao considerar a inter-relação entre nutrientes, a interpretação dos valores absolutos de níveis de fertilidade para $\mathrm{Ca}$, Mg e $\mathrm{K}$ não é tão simples. Por exemplo: para a maioria das culturas, o nível crítico de $\mathrm{Mg}$ no solo é $5 \mathrm{mmol} / \mathrm{dm}^{3}$, mas, na presença de elevadas adubações potássicas, deve ser elevado para $9 \mathrm{mmol} / \mathrm{dm}^{3}$ (Raij et al., 1997) 
Diante destes resultados, observa-se a importância da análise das relações entre os cátions ( $\mathrm{Ca}, \mathrm{Mg}$ e $\mathrm{K}$ ) e destes na CTC do solo como um fator auxiliar para análise de sua disponibilidade no solo. Segundo Raij et al. (1997), a melhor alternativa de análise de disponibilidade desses cátions no solo é considerar os teores absolutos como fundamentais, indicando a quantidade existente do nutriente e as relações com outros cátions como um fator secundário que afeta a disponibilidade.

A intensidade de pastejo teve pouco efeito sobre as concentrações de potássio e cálcio nas diferentes partes da planta, exceção feita para o potássio, que teve sua concentração reduzida nos CB nas intensidades de pastejo média e baixa em relação à verificada no pastejo mais intenso (Tabela 12).

Ribeiro et al. (1999), trabalhando com capim Elefante cv. Mott, em pastejo rotacionado, em duas alturas pré-pastejo (80 e $120 \mathrm{~cm}$ ), também encontraram diferença na concentração de potássio nos colmos entre os tratamentos, sendo $43,2 \mathrm{~g} / \mathrm{kg}$ MS no tratamento de $80 \mathrm{~cm}$ e $29,2 \mathrm{~g} / \mathrm{kg}$ MS no tratamento de $120 \mathrm{~cm}$. Além disso, a fração CB também é composta por colmos mais bainhas senescidos, e, devido à mobilidade do potássio na planta e à menor eficiência de pastejo no tratamento de baixa intensidade (maior quantidade de material morto), as concentrações de potássio nos CB nos tratamentos menos intensos podem ser menores.

As concentrações de magnésio e enxofre nas partes da planta de capim Tanzânia são apresentadas na Tabela 14. Observa-se que as concentrações desses minerais foram maiores no período 03 , quando as taxas de acúmulo de massa seca foram menores, comportamento semelhante ao observado para 0 nitrogênio. 
Tabela 14. Concentração de magnésio e enxofre nas partes da planta de capim Tanzânia irrigado em função dos períodos de coleta e das intensidades de pastejo

\begin{tabular}{lcccccc}
\hline \multirow{2}{*}{$\begin{array}{l}\text { Partes da } \\
\text { planta }\end{array}$} & \multicolumn{5}{c}{ Período de coleta } & \multicolumn{4}{c}{ Intensidade de pastejo } \\
& P1 & P2 & P3 & Alta & Média & Baixa \\
\hline FE & 2,2 b & $2,4 \mathrm{~b}$ & $2,7 \mathrm{a}$ & $2,4 \mathrm{~A}$ & $2,4 \mathrm{~A}$ & $2,4 \mathrm{~A}$ \\
LFRE & $3,4 \mathrm{~b}$ & $3,5 \mathrm{~b}$ & $4,8 \mathrm{a}$ & $3,9 \mathrm{~A}$ & $3,9 \mathrm{~A}$ & $3,8 \mathrm{~A}$ \\
LFM & 4,8 b & $4,5 \mathrm{~b}$ & $5,6 \mathrm{a}$ & $5,3 \mathrm{~A}$ & $5,0 \mathrm{~A}$ & $4,6 \mathrm{~A}$ \\
CB & $3,3 \mathrm{~b}$ & $3,0 \mathrm{~b}$ & $3,8 \mathrm{a}$ & $3,5 \mathrm{~A}$ & $3,4 \mathrm{~A}$ & $3,3 \mathrm{~A}$ \\
PT & $3,3 \mathrm{~b}$ & $3,2 \mathrm{~b}$ & $4,0 \mathrm{a}$ & $3,6 \mathrm{~A}$ & $3,5 \mathrm{~A}$ & $3,4 \mathrm{~A}$ \\
& & & & & & \\
& $1,2 \mathrm{~b}$ & $1,3 \mathrm{~b}$ & $1,6 \mathrm{a}$ & $1,4 \mathrm{~A}$ & $1,4 \mathrm{~A}$ & $1,3 \mathrm{~A}$ \\
FE & $1,2 \mathrm{~b}$ & $1,2 \mathrm{~b}$ & $1,5 \mathrm{a}$ & $1,4 \mathrm{~A}$ & $1,3 \mathrm{~A}$ & $1,3 \mathrm{~A}$ \\
LFRE & $1,1 \mathrm{~b}$ & $1,1 \mathrm{~b}$ & $1,4 \mathrm{a}$ & $1,3 \mathrm{~A}$ & $1,2 \mathrm{AB}$ & $1,1 \mathrm{~B}$ \\
LFM & $0,8 \mathrm{~b}$ & $0,8 \mathrm{~b}$ & $1,0 \mathrm{a}$ & $1,0 \mathrm{~A}$ & $0,9 \mathrm{~B}$ & $0,8 \mathrm{~B}$ \\
CB & $1,1 \mathrm{~b}$ & $1,0 \mathrm{~b}$ & $1,3 \mathrm{a}$ & $1,2 \mathrm{~A}$ & $1,1 \mathrm{AB}$ & $1,0 \mathrm{~B}$ \\
PT & &
\end{tabular}

FE - Folha em expansão; LFRE - Lâmina de folha recém-expandida; LFM - Lâmina de folha madura; CB - Colmo mais bainha; PT - Planta toda.

P1 - 30/10/1999 a 14/02/2000; P2 - 15/02/2000 a 01/06/2000; P3 - 02/06/2000 a 23/10/2000.

Intensidade de pastejo alta, média e baixa - 1.000, 2.500 e $4.000 \mathrm{~kg} \mathrm{MSV/ha,} \mathrm{respectivamente,} \mathrm{de} \mathrm{resíduo} \mathrm{pós-pastejo.}$

* Médias seguidas pela mesma letra na linha (minúscula para período de coleta e maiúscula para tratamento) não são diferentes ( $p>0.05)$ pelo teste de Tukey.

A concentração de magnésio neste estudo (3,2 a 4,0 g/kg MS na PT) está dentro da faixa de suficiência proposta por Werner et al. (1997) de 1,5 a $5,0 \mathrm{~g} / \mathrm{kg}$ MS na parte aérea de capim Colonião, mas abaixo (3,4 e 4,8 g/kg MS na LFRE) do nível critico determinado por Pereira (2001) 4,2 g/kg MS nas LFRE de capim Mombaça no primeiro e no segundo corte, realizados ao 30 e 21 dias de crescimento. Entretanto, os valores obtidos nesta pesquisa estão próximos da concentração média de magnésio na parte aérea de 280 gramíneas forrageiras (3,6 g/kg MS), determinada em avaliação realizada por Skerman \& Riveres (1992). Faquin et al. (1994) encontraram, em seu tratamento completo, 
concentração de 3,0 g/kg MS de magnésio na parte aérea dessa forrageira. Deste modo, a concentração de magnésio nas diferentes partes da planta de capim Tanzânia, obtida neste trabalho, encontra-se adequada, embora próxima dos níveis críticos determinados por outros estudos. Este fato deve ressaltar a importância de um bom manejo da adubação potássica, pois esta pode interferir nas concentrações de magnésio por meio de inibição competitiva. Deve-se ressaltar que o nível de magnésio no solo desta pesquisa estava alto (20,9 e $19,9 \mathrm{mmol}_{\mathrm{d}} / \mathrm{dm}^{3}$ ) (Tabelas 2 e 3 ), considerando os valores de $8 \mathrm{mmol} / \mathrm{dm}^{3}$ indicados por Raij et al. (1997). Entretanto, as concentrações de magnésio na planta não refletiram essa magnitude de diferença observada nos níveis desse nutriente no solo.

As concentrações de enxofre encontradas por Hoffmann (1992) no capim Colonião aos 46 dias de crescimento demonstram que a faixa de suficiência é 0,9 a 1,1 g/kg MS na parte aérea e 0,8 a 1,0 g/ $\mathrm{kg}$ MS nas folhas. Monteiro \& Carriel (1987) estudaram os efeitos da aplicação de enxofre para cultivo de capim Colonião, demonstrando que a concentração de enxofre para atingir a máxima produção foi $1,8 \mathrm{~g} / \mathrm{kg}$ MS na parte aérea da forrageira. Segundo Malavolta et al. (1997), os valores adequados desse nutriente na parte aérea de capim Colonião são 1,1 a 1,5 g/kg MS. Com base nesses resultados, os valores encontrados neste trabalho e apresentados na Tabela 14 (0,8 a 1,6 g/kg MS) podem ser considerados adequados para o bom desenvolvimento dessa forrageira.

A avaliação da concentração de magnésio nas diferentes intensidades de pastejo demonstra que os tratamentos não influenciaram a concentração do elemento, existindo, porém, tendência de terem sido observadas concentrações menores do nutriente quando a intensidade de pastejo foi baixa. Cecato et al. (2001), manejando capim Tanzânia em diferentes alturas (20, 40, 60 e 80 cm) em lotação contínua, demonstraram que as concentrações de magnésio nas lâminas foliares e colmos decresciam em função da altura. 
Devido às alterações na física do solo, demonstradas por Da Silva et al. (2003) na mesma área experimental, por meio do aumento do IC no tratamento de alta intensidade (9,92 Mpa), e as alterações no sistema radicular em função dos tratamentos impostos, como demonstrado por Pagoto (2001) no decorrer deste experimento, determinando uma retomada mais lenta do crescimento do sistema radicular no tratamento de alta intensidade de pastejo (21 dias póspastejo) em comparação ao verificado nos tratamentos de média e baixa intensidade de pastejo, os quais retornavam o crescimento aos 12 dias póspastejo, esperava-se que as plantas manejadas mais intensamente apresentassem maiores limitações nutricionais em relação aos manejos menos intensos. Entretanto, parece que as limitações físicas do solo e do crescimento do sistema radicular, prejudicadas pela maior intensidade de pastejo, foram compensadas pela maior fertilidade do solo ao final do experimento (Tabela 15).

Tabela 15. Análise química da terra da área experimental, coletada em fevereiro de 2001, nas camadas de 10 a $20 \mathrm{~cm}$ e 20 a $40 \mathrm{~cm}$ (média dos tratamentos)

\begin{tabular}{cccccccccccccc}
\hline Camada & M.O. & $\mathrm{P}$ & $\mathrm{S}-\mathrm{SO} 4$ & $\mathrm{~K}$ & $\mathrm{Ca}$ & $\mathrm{Mg}$ & $\mathrm{T}$ & $\mathrm{V}$ & $\mathrm{B}$ & $\mathrm{Cu}$ & $\mathrm{Mn}$ & $\mathrm{Zn}$ & $\mathrm{Fe}$ \\
\hline \multirow{2}{*}{$10-20$} & $\mathrm{~g} / \mathrm{dm}^{3}$ & $-----\mathrm{mg} / \mathrm{dm}^{3}---$ & & $-------\mathrm{mmolc}^{3} \mathrm{dm}^{3}-----$ & $\%$ & $-------------\mathrm{mg}^{3} \mathrm{dm}^{3}---------------$ \\
$20-40$ & 23 & 25,6 & 5,2 & 40 & 20 & 96 & 68 & 0,26 & 5,8 & 65 & 4,1 & 48 \\
& 23 & 8 & 73,7 & 2,4 & 32 & 15 & 88 & 56 & 0,20 & 3,7 & 20 & 1,0 & 30 \\
\hline
\end{tabular}

As concentrações de enxofre nas partes da planta mostram a mesma tendência que o magnésio, mas o tratamento com alta pressão de pastejo apontou maiores concentrações do elemento na PT, LFM e CB quando comparado ao manejo com baixa intensidade de pastejo (Tabela 14). As concentrações de enxofre nas LFM e PT em planta submetida à intensidade de pastejo média não diferiram daquelas determinadas no pastejo com intensidades alta e baixa.

Em revisão realizada por Werner \& Monteiro (1988), foi apontado que as proteínas apresentam proporção constante entre nitrogênio e enxofre, sendo 
essa relação utilizada para determinar o estado nutricional de plantas. A relação adequada é igual a 14:1 a 20:1, onde os menores valores são observados em gramíneas e os maiores, em leguminosas. A Tabela 16 apresenta as relações entre nitrogênio e enxofre nas diferentes partes do capim Tanzânia submetido a três intensidades de pastejo. Observa-se que as intensidades de pastejo não influenciaram a relação N:S, variando entre 14,4 e 17,0 nas diferentes folhas e entre 10,7 e 12,0 nos CB.

Tabela 16. Relação nitrogênio:enxofre nas partes da planta de capim Tanzânia irrigado em função das intensidades de pastejo

\begin{tabular}{|c|c|c|c|}
\hline \multirow{3}{*}{ Partes da planta } & \multicolumn{3}{|c|}{ Relação N:S } \\
\hline & \multicolumn{3}{|c|}{ Intensidade de pastejo } \\
\hline & Alta & Média & Baixa \\
\hline FE & $15,5 \mathrm{~A}$ & $\overline{14,4 \mathrm{~A}}$ & $\overline{15,5 \mathrm{~A}}$ \\
\hline LFRE & $16,5 \mathrm{~A}$ & $16,3 \mathrm{~A}$ & $16,2 \mathrm{~A}$ \\
\hline LFM & $17.0 \mathrm{~A}$ & $16,2 \mathrm{~A}$ & $16,4 \mathrm{~A}$ \\
\hline $\mathrm{CB}$ & $10,7 \mathrm{~A}$ & $10,9 \mathrm{~A}$ & $12,0 \mathrm{~A}$ \\
\hline
\end{tabular}

FE - Folha em expansão; LFRE - Lâmina de folha recém-expandida; LFM - Lâmina de folha madura; CB - Colmo mais bainha.

P1 - 30/10/1999 a 14/02/2000; P2 - 15/02/2000 a 01/06/2000; P3 - 02/06/2000 a 23/10/2000.

Intensidade de pastejo alta, média e baixa - 1.000, 2.500 e $4.000 \mathrm{~kg} \mathrm{MSV/ha,} \mathrm{respectivamente,} \mathrm{de} \mathrm{resíduo} \mathrm{pós-pastejo.}$

* Médias seguidas pela mesma letra na linha (maiúscula para tratamento) não são diferentes ( $p>0.05)$ pelo teste de Tukey.

Analisando as Tabelas 10 e 14, observa-se comportamento similar com relação às concentrações de nitrogênio e enxofre nas diferentes partes da planta em função das intensidades de pastejo, embora esses nutrientes apresentem comportamentos opostos quanto à redistribuição na planta, ou seja, o nitrogênio tem alta e o enxofre, baixa mobilidade na planta. Deste modo, a menor concentração de enxofre na PT, LFM e CB no tratamento de baixa intensidade de pastejo pode ser decorrente de uma menor necessidade desse nutriente, devido à redução da quantidade de proteína, determinando a relação $\mathrm{N}: \mathrm{S}$ constante na planta (Tabela 16). 
As concentrações de boro podem ser observadas na Tabela 17. A análise dos dados demonstra que as concentrações de boro foram pouco influenciadas pelos períodos de coleta e intensidades de pastejo, apresentando valores entre 7,4 e 8,1 mg/kg MS na PT de capim Tanzânia. Neste sentido, esses valores estão próximos dos indicados por Malavolta et al. (1997) como adequados para a parte aérea de capim Colonião (7 a $10 \mathrm{mg} / \mathrm{kg} \mathrm{MS}$ ) e abaixo dos valores propostos por Werner et al. (1997) - 10 a $30 \mathrm{mg} / \mathrm{kg} \mathrm{MS} \mathrm{-} \mathrm{também}$ para a parte aérea de capim Colonião. Em revisão realizada por Monteiro et al. (2001), estes demonstraram que a faixa de suficiência para boro em gramíneas seria 6 a $10 \mathrm{mg} / \mathrm{kg}$ MS. Gallo et al. (1974) determinaram a concentração de boro na parte aérea de capim Colonião, cultivados no Estado de São Paulo, sendo $15 \mathrm{mg} / \mathrm{kg}$ MS. Observa-se que as concentrações médias nas FE (7,7 $\mathrm{mg} / \mathrm{kg} \mathrm{MS}$ ) e nas LFRE (8,0 mg/kg MS) são próximas. Deste modo, tendo o boro baixa mobilidade na planta, os resultados indicam que esse nutriente não deve limitar o desenvolvimento da planta forrageira em estudo.

Por outro lado, com relação aos teores desse nutriente no solo, estes apresentam níveis de 0,45 e $0,34 \mathrm{mg} / \mathrm{dm}^{3}$ no início e no final do experimento, respectivamente (Tabelas 2 e 3). Esses valores são considerados níveis médios segundo Raij et al. (1997), que apresentaram valores de 0,21 a $0,6 \mathrm{mg} / \mathrm{dm}^{3}$. Monteiro et al. (2001), em revisão sobre o assunto, apontaram que os resultados dos estudos com micronutrientes em gramíneas forrageiras, em sua maioria, determinam respostas positivas às adubações quanto à concentração dos micronutrientes na planta, mas não promovem incrementos na produção de massa seca. 
Tabela 17. Concentração de boro nas partes da planta de capim Tanzânia irrigado em função dos períodos de coleta e das intensidades de pastejo

\begin{tabular}{lcccccc}
\hline \multirow{2}{*}{$\begin{array}{c}\text { Partes da } \\
\text { planta }\end{array}$} & \multicolumn{5}{c}{ Período de coleta } & \multicolumn{3}{c}{ Intensidade de pastejo } \\
& P1 & P2 & P3 & Alta & Média & Baixa \\
\hline FE & $7,9 \mathrm{a}$ & $8,0 \mathrm{a}$ & $7,4 \mathrm{a}$ & $7,6 \mathrm{~A}$ & $7,8 \mathrm{~A}$ & $7,9 \mathrm{~A}$ \\
LFRE & $7.6 \mathrm{a}$ & $8,7 \mathrm{a}$ & $7,7 \mathrm{a}$ & $8,1 \mathrm{~A}$ & $7,8 \mathrm{~A}$ & $8,2 \mathrm{~A}$ \\
LFM & $9,5 \mathrm{a}$ & $9,4 \mathrm{a}$ & $8,4 \mathrm{a}$ & $9,8 \mathrm{~A}$ & $8,7 \mathrm{~A}$ & $8,9 \mathrm{~A}$ \\
CB & $6,5 \mathrm{a}$ & $7,0 \mathrm{a}$ & $7,2 \mathrm{a}$ & $7,6 \mathrm{~A}$ & $6,5 \mathrm{~A}$ & $6,6 \mathrm{~A}$ \\
PT & $7,7 \mathrm{a}$ & $8,0 \mathrm{a}$ & $7,6 \mathrm{a}$ & $8,2 \mathrm{~A}$ & $7,5 \mathrm{~A}$ & $7,7 \mathrm{~A}$
\end{tabular}

FE - Folha em expansão; LFRE - Lâmina de folha recém-expandida; LFM - Lâmina de folha madura; CB - Colmo mais bainha. P1 - 30/10/1999 a 14/02/2000; P2 - 15/02/2000 a 01/06/2000; P3 - 02/06/2000 a 23/10/2000.

Intensidade de pastejo alta, média e baixa - 1.000, 2.500 e $4.000 \mathrm{~kg} \mathrm{MSV} / \mathrm{ha}$, respectivamente, de resíduo pós-pastejo.

* Médias seguidas pela mesma letra na linha (minúscula para período de coleta e maiúscula para tratamento) não são diferentes $(p>0.05)$ pelo teste de Tukey.

As concentrações de cobre e zinco são apresentadas na Tabela 18. Observa-se decréscimo da concentração de cobre no período 02 , com posterior recuperação no período 03 , apresentando comportamento semelhante ao já observado para o potássio, no qual as concentrações foram inversas aos acúmulos médios de massa seca. De maneira diferente, o zinco demonstra distribuição de concentração nas partes da planta pouco influenciada pelos períodos, ocorrendo diferenças significativas apenas entre os períodos 01 e 02 nas LFM e entre o período 01 e os demais no CB e na PT.

Malavolta et al. (1997) demonstraram existir efeito interiônico entre zinco e cálcio, por meio de inibição competitiva. Deste modo, ao analisar a Tabela 12, observa-se aumento da concentração de cálcio na LFM entre os períodos 01 e 02, o que poderia ocasionar redução da concentração de zinco nesse período, como observado na Tabela 18. Por outro lado, as concentrações de cálcio nos CB no período 01 são menores em relação às verificadas nos demais períodos, comportamento oposto ao apresentado pela concentração de zinco nos CB (Tabela 18). 
Em trabalho realizado por Monteiro et al. (1999), com Brachiaria brizantha cv. Marandu, os autores verificaram que as concentrações de zinco no tecido vegetal variaram de acordo com a parte da planta analisada, apresentando valores próximos a $19 \mathrm{mg} / \mathrm{kg}$ MS nas FE, $16 \mathrm{mg} / \mathrm{kg}$ MS nas LFER, $25 \mathrm{mg} / \mathrm{kg}$ MS nas LFM e $13 \mathrm{mg} / \mathrm{kg}$ MS nos CB. Observa-se que os valores na Tabela 18 se encontram acima dos encontrados por esses autores, principalmente os determinados nos CB (34,6 a 47,8 mg/kg MS).

Considerando os resultados apresentados por Faquin et al. (1994) e Werner et al. (1997) para a parte aérea do capim Colonião, os níveis críticos para cobre e zinco são, respectivamente, 5 e 20 mg/kg MS (Faquin et al., 1994) e 4 a 14 e 20 a $50 \mathrm{mg} / \mathrm{kg}$ MS para cobre e zinco, respectivamente (Werner et al., 1997). Observa-se que as concentrações obtidas (Tabela 18) se encontram acima dos valores citados, demonstrando que a planta forrageira teria suas exigências nutricionais atendidas em todos os períodos e tratamentos. 
Tabela 18. Concentração de cobre e zinco nas partes da planta de capim Tanzânia irrigado em função dos períodos de coleta e das intensidades de pastejo

\begin{tabular}{|c|c|c|c|c|c|c|}
\hline \multirow{3}{*}{$\begin{array}{c}\text { Partes da } \\
\text { planta }\end{array}$} & \multicolumn{6}{|c|}{ Cobre $(\mathrm{mg} / \mathrm{kg})^{\star}$} \\
\hline & \multicolumn{3}{|c|}{ Período de coleta } & \multicolumn{3}{|c|}{ Intensidade de pastejo } \\
\hline & P1 & P2 & P3 & Alta & Média & Baixa \\
\hline$\overline{\mathrm{FE}}$ & $16,6 \mathrm{a}$ & $13,3 \mathrm{~b}$ & $16,1 \mathrm{a}$ & $15,2 \mathrm{~A}$ & $15,9 \mathrm{~A}$ & $14,9 \mathrm{~A}$ \\
\hline LFRE & $14,9 \mathrm{a}$ & $11,8 \mathrm{~b}$ & $14,1 \mathrm{a}$ & $13,6 \mathrm{~A}$ & $14,0 \mathrm{~A}$ & $13,2 \mathrm{~A}$ \\
\hline LFM & $13,6 \mathrm{a}$ & $10,4 \mathrm{~b}$ & $11,7 a b$ & $12,7 \mathrm{~A}$ & $12,3 \mathrm{~A}$ & $10,7 \mathrm{~A}$ \\
\hline \multirow[t]{2}{*}{ PT } & $15,1 \mathrm{a}$ & $10,1 \mathrm{~b}$ & $13,1 \mathrm{a}$ & $13,3 \mathrm{~A}$ & $13,3 \mathrm{~A}$ & $11,7 \mathrm{~A}$ \\
\hline & \multicolumn{6}{|c|}{ - Zinco $(\mathrm{mg} / \mathrm{kg})^{\star}$} \\
\hline FE & $28,3 \mathrm{a}$ & $27,0 \mathrm{a}$ & $28,6 \mathrm{a}$ & $28,0 \mathrm{~A}$ & $28,2 \mathrm{~A}$ & $27,8 \mathrm{~A}$ \\
\hline LFRE & $24,7 \mathrm{a}$ & $24,1 \mathrm{a}$ & $23,3 \mathrm{a}$ & $24,5 \mathrm{~A}$ & $24,1 \mathrm{~A}$ & $23,5 \mathrm{~A}$ \\
\hline LFM & $24,9 \mathrm{a}$ & $22,2 \mathrm{~b}$ & $24,1 a b$ & $25,1 \mathrm{~A}$ & $24,2 \mathrm{AB}$ & $22,0 \mathrm{~B}$ \\
\hline CB & $34,7 \mathrm{~b}$ & $44,7 \mathrm{a}$ & $47,9 \mathrm{a}$ & $39,8 \mathrm{~A}$ & $43,6 \mathrm{~A}$ & $41,7 \mathrm{~A}$ \\
\hline PT & $29,7 \mathrm{~b}$ & $34,3 \mathrm{a}$ & $34,0 \mathrm{a}$ & $32,7 \mathrm{~A}$ & $32,6 \mathrm{~A}$ & $32,7 \mathrm{~A}$ \\
\hline
\end{tabular}

FE - Folha em expansão; LFRE - Lâmina de folha recém-expandida; LFM - Lâmina de folha madura; CB - Colmo mais bainha; PT - Planta toda.

P1 - 30/10/1999 a 14/02/2000; P2 - 15/02/2000 a 01/06/2000; P3 - 02/06/2000 a 23/10/2000.

Intensidade de pastejo alta, média e baixa - 1.000, 2.500 e $4.000 \mathrm{~kg}$ MSV/ha, respectivamente, de resíduo pós-pastejo.

* Médias seguidas pela mesma letra na linha (minúscula para período de coleta e maiúscula para tratamento) não são diferentes $(p>0.05)$ pelo teste de Tukey.

A análise da Tabela 18 mostra que não houve efeito dos tratamentos nas concentrações dos nutrientes em estudo, ocorrendo apenas efeito para o zinco nas LFM, as quais, no tratamento de maior intensidade de pastejo, têm maiores concentrações de zinco em relação às submetidas ao tratamento de menor intensidade.

A intensidade de pastejo tem demonstrado pouca influência sobre a concentração dos minerais nas partes da planta forrageira, e, quando ocorre, está, na maior parte das vezes, como nos casos de nitrogênio, fósforo, enxofre e zinco, relacionada às lâminas de folhas maduras (LFM). Deste modo, observa-se que a intensidade de pastejo pode influenciar as concentrações dos 
elementos nessa parte da planta (LFM), o que sugere que esta deve ser preterida para análise do estado nutricional de Panicum maximum cv. Tanzânia sob tais condições. Neste sentido, um dos fatores que poderia explicar a influência dos tratamentos na concentração de N e P na LFM está relacionado à redistribuição dos nutrientes na planta, que ocorre predominantemente pelo floema. As LFM são compostas por folhas mais velhas em relação às LFRE e, também, por folhas senescidas. Deste modo, é nessa parte da planta que as diferenças de eficiência de pastejo entre os tratamentos, apresentadas por Penati (2002), devem ser observadas, ocorrendo maior quantidade de material senescido no tratamento de menor intensidade de pastejo. Assim, nesse tratamento, pode ocorrer maior concentração de nutrientes pouco móveis e imóveis e menores concentrações de nutrientes móveis, quando comparado com o tratamento de maior intensidade.

A Tabela 19 demonstra a interação entre os tratamentos e períodos de coleta na concentração de cobre no colmo mais bainha (CB). Observa-se que houve maior concentração de cobre nas plantas de capim Tanzânia submetidas ao pastejo de intensidade média $(18,3 \mathrm{mg} / \mathrm{kg} \mathrm{MS})$ do que nas plantas manejadas com intensidade baixa de pastejo $(11,5 \mathrm{mg} / \mathrm{kg} \mathrm{MS})$ durante $\mathrm{o}$ período 01. Com relação aos períodos de coletas, estes apresentaram diferenças no tratamento de média intensidade, ocorrendo maior concentração de cobre no período 01. 
Tabela 19. Concentração de cobre no colmo mais bainha (CB) em mg/kg MS do capim Tanzânia irrigado em função dos períodos de coleta e das intensidades de pastejo

\begin{tabular}{cccc}
\hline \multirow{2}{*}{ Período de coleta } & Alta & Intensidade de pastejo * \\
& $15,75 \mathrm{aAB}$ & $18,33 \mathrm{aA}$ & Baixa \\
\hline 01 & $11,11 \mathrm{aA}$ & $8,77 \mathrm{bA}$ & $8,11 \mathrm{aA}$ \\
02 & $12,14 \mathrm{aA}$ & $11,57 \mathrm{bA}$ & $12,92 \mathrm{aA}$ \\
03 &
\end{tabular}

P1 - 30/10/1999 a 14/02/2000; P2 - 15/02/2000 a 01/06/2000; P3 - 02/06/2000 a 23/10/2000.

Intensidade de pastejo alta, média e baixa - 1.000, 2.500 e $4.000 \mathrm{~kg} \mathrm{MSV/ha,} \mathrm{respectivamente,} \mathrm{de} \mathrm{resíduo} \mathrm{pós-pastejo.}$

* Médias seguidas pela mesma letra (minúscula na coluna e maiúscula na linha) não são diferentes ( $p>0.05)$ pelo teste de Tukey.

As concentrações de ferro e manganês são apresentadas na Tabela 20, demonstrando que os elementos tiveram comportamentos opostos na distribuição de suas concentrações durante os períodos, exceto para LFM. O ferro apresentou maiores concentrações na PT no período 01 de pastejo (248 $\mathrm{mg} / \mathrm{kg} \mathrm{MS}$ ), enquanto o manganês esteve mais concentrado nas partes da planta colhidas no período 03 (140 mg/kg MS na PT).

Sabe-se que existe efeito interiônico entre ferro e manganês. $O$ manganês, por inibição competitiva, tem efeito negativo na absorção de ferro (Malavolta, et al., 1997). Deste modo, comportamentos opostos na distribuição de concentração desses elementos são esperados. No entanto, esse efeito não chegou a causar deficiência de ferro e/ou manganês, pois os dados obtidos por Werner et al. (1997) demonstram que a faixa de suficiência para esses elementos é 50 a $200 \mathrm{mg} / \mathrm{kg}$ MS para o ferro e 40 a $200 \mathrm{mg} / \mathrm{kg}$ MS para o manganês, enquanto Malavolta et al. (1997) indicam a faixa 100 a $150 \mathrm{mg} / \mathrm{kg}$ MS para ferro e 80 a $100 \mathrm{mg} / \mathrm{kg}$ MS para manganês. Assim, observa-se, na Tabela 20, que os valores obtidos são maiores que os apresentados por esses autores. 
Tabela 20. Concentração de ferro e manganês nas partes da planta de capim Tanzânia em função dos períodos de coleta e das intensidades de pastejo

\begin{tabular}{lcccccc}
\hline \multirow{2}{*}{$\begin{array}{l}\text { Partes da } \\
\text { planta }\end{array}$} & \multicolumn{5}{c}{ Período de coleta } & \multicolumn{3}{c}{ Intensidade de pastejo } \\
& P1 & P2 & P3 & Alta & Média & Baixa \\
\hline FE & $178 \mathrm{a}$ & $117 \mathrm{~b}$ & $148 \mathrm{~b}$ & $158 \mathrm{~A}$ & $135 \mathrm{~A}$ & $145 \mathrm{~A}$ \\
LFRE & $269 \mathrm{a}$ & $158 \mathrm{c}$ & $209 \mathrm{~b}$ & $263 \mathrm{~A}$ & $182 \mathrm{~B}$ & $182 \mathrm{~B}$ \\
LFM & $324 \mathrm{a}$ & $204 \mathrm{~b}$ & $269 \mathrm{a}$ & $302 \mathrm{~A}$ & $257 \mathrm{~A}$ & $229 \mathrm{~A}$ \\
CB & $162 \mathrm{a}$ & $85 \mathrm{~b}$ & $105 \mathrm{~b}$ & $135 \mathrm{~A}$ & $107 \mathrm{~A}$ & $100 \mathrm{~A}$ \\
PT & $248 \mathrm{a}$ & $139 \mathrm{~b}$ & $173 \mathrm{~b}$ & $222 \mathrm{~A}$ & $168 \mathrm{~B}$ & $170 \mathrm{~B}$ \\
& $----------------------~ M a n g a n e ̂ s ~(m g / k g)$ & ------------------ \\
FE & $72 \mathrm{~b}$ & $84 \mathrm{a}$ & $87 \mathrm{a}$ & $68 \mathrm{~A}$ & $94 \mathrm{~A}$ & $81 \mathrm{~A}$ \\
LFRE & $101 \mathrm{~b}$ & $109 \mathrm{~b}$ & $174 \mathrm{a}$ & $104 \mathrm{~A}$ & $139 \mathrm{~A}$ & $113 \mathrm{~A}$ \\
LFM & $127 \mathrm{~b}$ & $135 \mathrm{ab}$ & $154 \mathrm{a}$ & $118 \mathrm{~A}$ & $169 \mathrm{~A}$ & $129 \mathrm{~A}$ \\
CB & $115 \mathrm{~b}$ & $130 \mathrm{ab}$ & $154 \mathrm{a}$ & $124 \mathrm{~A}$ & $153 \mathrm{~A}$ & $121 \mathrm{~A}$ \\
PT & $104 \mathrm{~b}$ & $117 \mathrm{~b}$ & $140 \mathrm{a}$ & $108 \mathrm{~A}$ & $139 \mathrm{~A}$ & $113 \mathrm{~A}$ \\
\hline
\end{tabular}

FE - Folha em expansão; LFRE - Lâmina de folha recém-expandida; LFM - Lâmina de folha madura; CB - Colmo mais bainha; PT - Planta toda.

P1 - 30/10/1999 a 14/02/2000; P2 - 15/02/2000 a 01/06/2000; P3 - 02/06/2000 a 23/10/2000.

Intensidade de pastejo alta, média e baixa - 1.000, 2.500 e $4.000 \mathrm{~kg} \mathrm{MSV/ha,} \mathrm{respectivamente,} \mathrm{de} \mathrm{resíduo} \mathrm{pós-pastejo.}$ * Médias seguidas pela mesma letra (minúscula para período de coleta e maiúscula para tratamento) não são diferentes ( $p>0.05$ ) pelo teste de Tukey.

A influência dos tratamentos na concentração dos elementos ocorreu apenas para o ferro nas LFRE e PT, quando a planta forrageira foi submetida a alta intensidade de pastejo, sendo sua concentração (263 mg/kg MS na LFRE) maior que as concentrações obtidas nas plantas sob pastejo de média e baixa intensidade (182 mg/kg MS na LFRE). Por outro lado, a intensidade de pastejo não alterou a concentração de manganês nas diferentes partes da planta de capim Tanzânia (Tabela 20). 
Os resultados mostram que, exclusivamente para análise foliar para determinar o estado nutricional da planta em ferro, não seria indicado escolher a LFRE, pois o manejo do pastejo interferiu em suas concentrações.

Segundo Vitti (2001), os fatores que estão associados a deficiência e disponibilidade dos micronutrientes são: material de origem do solo; reação do solo $(\mathrm{pH})$; textura do solo; aeração do solo; práticas culturais; características genéticas da planta; e desbalanceamento entre cátions metálicos.

Neste aspecto, o pH do solo tem grande importância na disponibilidade desses elementos. A elevação do $\mathrm{pH}$ do solo provoca a diminuição da disponibilidade de cátions, como $\mathrm{Fe}$ e $\mathrm{Mn}$, por meio da precipitação pela hidroxila $\left(\mathrm{OH}^{-}\right)$na solução do solo, e de $\mathrm{Zn}$, pela adsorção específica na fração coloidal do solo. Por outro lado, a disponibilidade de ânions, como $\mathrm{Mo} \mathrm{e} \mathrm{Cl}$, é aumentada com a elevação do pH do solo. Deste modo, devido aos valores de saturação de bases (V\%) do solo deste experimento, $66 \%$ na camada $0-20 \mathrm{~cm}$, e considerando a alta relação da $\mathrm{V} \% \mathrm{com}$ o pH do solo (Catani \& Gallo 1955), esperava-se baixa disponibilidade de cátions como $\mathrm{Fe}, \mathrm{Mn}$ e $\mathrm{Zn}$ no solo, refletindo-se em menores concentrações desses nutrientes na planta. No entanto, como apresentado, as concentrações de $\mathrm{Fe}, \mathrm{Mn}$ e $\mathrm{Zn}$ encontram-se acima dos níveis críticos e da faixa de suficiência estabelecida (Tabelas 18 e 20).

Esperavam-se diferenças no requerimento nutricional da planta forrageira manejada sob diferentes intensidades de pastejo, visto que essas diferenças de manejo podem promover alterações no acúmulo e disponibilidade de forragem e no desempenho animal (Penati, 2002), no consumo animal em pastejo (Balsalobre, 2002) e na reciclagem de nutrientes, via animal e via planta. $O$ manejo do pastejo também poderia alterar o balanço nutricional das plantas forrageiras devido a fatores relacionados à física do solo, como a compactação (Da Silva et al., 2003), e a alterações no desenvolvimento do sistema radicular (Pagoto, 2001). No entanto, possivelmente devido às adubações de correções realizadas no início do experimento, à boa fertilidade do solo e às altas 
adubações de produção, não foi possível observar diferenças nas concentrações dos nutrientes em plantas de capim Tanzânia manejado sob diferentes intensidades de pastejo.

Deste modo, com exceção ao cálcio, que apresentou concentrações próximas aos níveis críticos internos, todos os nutrientes apresentaram, em todos os tratamentos, concentrações consideradas adequadas. Sendo assim, tem-se a possibilidade de comparar as diferentes partes da planta forrageira para determinar, em situação de equilíbrio nutricional, qual destas melhor demonstra o estado nutricional em que a planta se encontra, sem que o manejo influencie sua concentração.

Neste sentido, Garcez Neto et al. (2002) estudaram as respostas morfogênicas de capim Mombaça sob diferentes alturas de corte (5, 10 e 20 $\mathrm{cm}$ ) em casa de vegetação, demonstrando que a duração de vida da folha foi aumentada com a altura de corte, sendo 32, 38 e 45 dias para 5, 10 e $20 \mathrm{~cm}$, respectivamente. Deste modo, em ambiente que impõe diferenças de manejo a partir da intensidade promovida por pastejo ou corte, as características morfológicas e estruturais do dossel forrageiro podem ser alteradas. Lâminas foliares ocupando a mesma posição no perfilho podem apresentar diferenças em tamanho e duração de vida. Neste sentido, segundo Raij (1991) e Malavolta et al. (1997), a idade do tecido vegetal influencia a concentração dos nutrientes nesse tecido. Os nutrientes nitrogênio, fósforo, potássio, magnésio, cloro e molibdênio são móveis na planta, e folhas mais jovens apresentam concentrações mais elevadas que folhas velhas. Para outros elementos, como cálcio, enxofre, zinco, cobre, manganês, ferro e boro, freqüentemente, ocorre um aumento relativo com o envelhecimento do tecido vegetal.

No entanto, para os nutrientes estudados, com exceção ao ferro, as lâminas de folhas recém-expandidas (LFRE) neste trabalho não foram influenciadas pela intensidade de pastejo impostas pelos tratamentos. Assim, devem ser indicadas para expressar o estado nutricional dessa forrageira, visto 
que esta apresenta melhor correlação com a produção de massa seca (Rossi, 1999; Lavres Junior, 2001).

\subsection{Pastejo simulado, consumo e reciclagem de nutrientes}

Os resultados das concentrações de nitrogênio, fósforo, potássio, cálcio, magnésio e enxofre na parte da planta colhida por meio de simulação de pastejo (pastejo simulado), em função das intensidades de pastejo e do período experimental, são apresentadas na Tabela 21. A interação entre tratamento e período não foi significativa $(p>0,05)$. Dessa forma, foram efetuadas comparações das médias entre tratamentos e entre períodos.

As concentrações de $\mathrm{N}, \mathrm{P}, \mathrm{Mg}$ e $\mathrm{S}$ tiveram comportamento crescente ao longo do período experimental. O aumento da concentração de $\mathrm{P}$ ocorreu entre os períodos 01 e 02. Para os outros nutrientes citados, o aumento ocorreu entre os períodos 02 e 03, apresentando nestes suas maiores concentrações. Esse comportamento é semelhante ao discutido para esses nutrientes nas diferentes partes do capim Tanzânia. Deste modo, as considerações feitas anteriormente devem ser válidas, visto que o pastejo simulado é uma composição de diferentes partes da planta forrageira. Por outro lado, as concentrações de $\mathrm{K} \mathrm{e}$ Ca não seguiram a mesma tendência. Houve redução da concentração de $\mathrm{K}$ entre os períodos 01 e 02. Do mesmo modo, a análise das concentrações nas LFRE e CB do capim Tanzânia demonstra redução da concentração de K no período 02 (Tabela 12). De maneira contrária, no caso do Ca, as concentrações do pastejo simulado foram constantes ao longo dos períodos, comportamento diferente das concentrações de Ca nas LFRE, FM e CB, que tiveram variações no decorrer do período experimental. 
Tabela 21. Concentração de nitrogênio, fósforo, potássio, cálcio, magnésio e enxofre no pastejo simulado de capim Tanzânia irrigado em função dos períodos de coletas e das intensidades de pastejo

\begin{tabular}{|c|c|c|c|c|c|c|c|}
\hline & \multicolumn{6}{|c|}{ Minerais $(\mathrm{g} / \mathrm{kg})$ * } \\
\hline & & Nitrogênio & Fósforo & Potássio & Cálcio & Magnésio & Enxofre \\
\hline \multirow{3}{*}{$\begin{array}{l}\text { Período de } \\
\text { coleta }\end{array}$} & 01 & $17,7 \mathrm{~b}$ & $1,8 \mathrm{~b}$ & $26,3 a$ & $3,4 \mathrm{a}$ & $3,2 \mathrm{~b}$ & $1,2 \mathrm{~b}$ \\
\hline & 02 & $18,9 \mathrm{~b}$ & $2,0 \mathrm{a}$ & $22,9 \mathrm{~b}$ & $3,0 \mathrm{a}$ & $3,3 \mathrm{~b}$ & $1,3 \mathrm{~b}$ \\
\hline & 03 & $21,8 \mathrm{a}$ & $1,9 a b$ & $24,0 \mathrm{~b}$ & $3,4 \mathrm{a}$ & $4,3 \mathrm{a}$ & $1,5 \mathrm{a}$ \\
\hline \multirow{3}{*}{$\begin{array}{l}\text { Intensidade } \\
\text { de pastejo }\end{array}$} & Alta & $20,2 \mathrm{~A}$ & $2,0 \mathrm{~A}$ & $26,9 \mathrm{~A}$ & $3,0 \mathrm{~A}$ & $3,7 \mathrm{~A}$ & 1,3 A \\
\hline & Média & $18,7 \mathrm{~A}$ & $1,9 \mathrm{~A}$ & $24,0 \mathrm{~B}$ & $3,3 \mathrm{~A}$ & $3,5 \mathrm{~A}$ & $1,2 \mathrm{~A}$ \\
\hline & Baixa & $19,4 \mathrm{~A}$ & $1,8 \mathrm{~A}$ & $22,9 \mathrm{~B}$ & $3,5 \mathrm{~A}$ & $3,6 \mathrm{~A}$ & $1,3 \mathrm{~A}$ \\
\hline
\end{tabular}

A intensidade de pastejo teve pouca influência nas concentrações dos minerais no pastejo simulado, sendo suas concentrações semelhantes entre os tratamentos. Esse comportamento era esperado, pois as concentrações nas FE, LFRE e CB tiveram pouca influência das intensidades de pastejo, e, possivelmente, são as partes que devem compor preferencialmente a dieta dos animais em pastejo. As concentrações de $\mathrm{K}$ nos $\mathrm{CB}$, porém, foram maiores no tratamento de alta intensidade quando comparadas às dos tratamentos de média e baixa intensidade de pastejo (Tabela 12). Deste modo, como os CB tiveram grande participação na produção total de massa seca (42 a 47\%, Tabela 13) e a forragem apresentou alta concentração de K (43 a 51 g/kg MS), esses aspectos podem ter influenciado as concentrações desse mineral no pastejo simulado. Neste sentido, o tratamento de alta intensidade, por ter maior eficiência de pastejo (75\%), deve proporcionar maior consumo de CB pelos animais, em relação ao tratamento de baixa intensidade, que teve uma eficiência de $47 \%$ (Penati, 2002). 
As Tabelas 22, 23 e 24 demonstram o consumo animal dos minerais por ciclo de pastejo, em função das intensidades de pastejo. A interação de tratamento e período foi significativa $(p<0,05)$ apenas para o consumo animal de $\mathrm{N}$ e Mg (Tabelas 22 e 24). Nesse caso, foram efetuadas comparações de médias entre tratamentos dentro de cada período e entre períodos dentro de cada tratamento.

Tabela 22. Estimativa do consumo animal de nitrogênio $\left(\mathrm{kg}^{*} \mathrm{ha}^{-1 *} \mathrm{ciclo}^{-2}\right)$ em capim Tanzânia em função dos períodos de coletas e das intensidades de pastejo

\begin{tabular}{|c|c|c|c|}
\hline \multirow{2}{*}{ Período de coleta } & \multicolumn{3}{|c|}{ Intensidade de pastejo } \\
\hline & Alta & Média & Baixa \\
\hline 01 & 35,5 aA & 35,3 aA & $31,4 \mathrm{aA}$ \\
\hline 02 & $38,7 \mathrm{aA}$ & $31,4 \mathrm{aA}$ & $26,1 \mathrm{aA}$ \\
\hline 03 & $44,9 \mathrm{aA}$ & $30,8 \mathrm{aB}$ & $25,0 \mathrm{aB}$ \\
\hline
\end{tabular}

Observa-se que os valores de consumo variam de 25,0 a $44,9 \mathrm{~kg} \mathrm{~N} ; 2,6$ a 4,0 kg P; 33,9 a 54,2 kg K; 5,0 a 6,1 kg Ca; 4,4 a 8,3 kg Mg; e 1,7 a 2,6 kg S por hectare, por ciclo de pastejo. Por outro lado, Wilkinson \& Lowrey (1973) determinaram o consumo dos animais por meio do pastejo, sendo $30 \mathrm{~kg} \mathrm{P}, 255$ $\mathrm{kg} \mathrm{K}, 27 \mathrm{~kg} \mathrm{Ca}, 18 \mathrm{~kg} \mathrm{Mg}$ e $22 \mathrm{~kg} \mathrm{~S}^{\star} \mathrm{ha}^{-1 \star} \mathrm{ano}^{-2}$.

A partir dos dados das Tabelas 22, 23 e 24, pode-se determinar 0 consumo anual de minerais, multiplicando os resultados pelos dez ciclos de pastejo realizados neste experimento. Assim, comparando os resultados obtidos aos de Wilkinson \& Lowrey (1973), observa-se que o consumo de P e S foi semelhante e o de $\mathrm{K}$, Ca e Mg, superior, como demonstram as Tabelas $23 \mathrm{e}$ 24. A maior quantidade de nutrientes consumidos neste experimento justifica-se pelas taxas de lotação empregadas, sendo 4,1 a 6,5 UA/ha, valores estes 
superiores ao utilizados por Wilkinson \& Lowrey (1973) 2,47 pares de vacasbezerro/ha.

Por outro lado, Primavesi et al. (2001) obtiveram, a partir dos cinco cortes de capim Coastcross, com aplicação de $200 \mathrm{~kg} \mathrm{~N} / \mathrm{ha}$ por corte, extração de 429 kg N, $35 \mathrm{~kg} \mathrm{P,} 392 \mathrm{~kg} \mathrm{~K}, 67 \mathrm{~kg} \mathrm{Ca}, 37 \mathrm{~kg} \mathrm{Mg} \mathrm{e} 40 \mathrm{~kg} \mathrm{~S}$ por hectare. Observa-se similaridade dos dados de consumo de minerais obtidos nos dez ciclos de pastejo realizados neste experimento, com adubações de $800 \mathrm{~kg} \mathrm{~N} / \mathrm{ha} / \mathrm{ano}$, com os dados apresentado por Primavesi et al. (2001), exceção feita ao consumo de $\mathrm{K}$, sendo este maior devido às maiores concentrações desse elemento no pastejo simulado (Tabela 21). Neste aspecto, a reciclagem de nutrientes assume um importante papel quando comparadas as adubações realizadas em áreas de corte com aquelas realizadas em áreas de pastejo.

Em áreas destinadas à produção de volumosos (silagem, feno etc.), as possibilidades de reciclagem tornam-se bem reduzidas, pois existe grande eficiência de colheita desse material. Igarasi (2002) mostrou que, para a forragem colhida por meio de corte, as perdas resultantes das atividades captação, corte e carregamento da forragem foram $4 \%$ da massa total e, neste caso, a reciclagem via animal não ocorre. Por outro lado, em ambiente de pastejo, os animais são menos eficientes na colheita (consumo) da forragem, como demonstrado por Tosi (1999), em pastagens adubadas de capim Tanzânia sob lotação rotacionada, determinando perdas de $1.050 \mathrm{~kg} \mathrm{MS} / \mathrm{ha}$ por ciclo de pastejo, equivalente a $28 \%$ da massa de forragem pré-pastejo. Assim, obtendo as quantidades de nutrientes extraídos via corte e consumidos no pastejo animal, o que é realmente exportado depende da capacidade de cada sistema de promover a reciclagem desses nutrientes. 
Tabela 23. Estimativa do consumo animal de fósforo, potássio, cálcio e enxofre $\left(\mathrm{kg}^{*} \mathrm{ha}^{-1 *} \mathrm{Ciclo}^{-2}\right)$ em capim Tanzânia irrigado em função das intensidades de pastejo

\begin{tabular}{ccccc}
\hline $\begin{array}{c}\text { Intensidade } \\
\text { de pastejo }\end{array}$ & Fósforo & Potássio & Cálcio & Enxofre \\
\hline Alta & $4,0 \mathrm{~A}$ & $54,2 \mathrm{~A}$ & $6,1 \mathrm{~A}$ & $2,6 \mathrm{~A}$ \\
Média & $3,3 \mathrm{~B}$ & $43,0 \mathrm{~B}$ & $5,9 \mathrm{~A}$ & $2,2 \mathrm{~B}$ \\
Baixa & $2,6 \mathrm{C}$ & 34,0 C & $5,1 \mathrm{~A}$ & $1,7 \mathrm{~B}$ \\
\hline
\end{tabular}

P1 - 30/10/1999 a 14/02/2000; P2 - 15/02/2000 a 01/06/2000; P3 - 02/06/2000 a 23/10/2000.

Intensidade de pastejo alta, média e baixa - 1.000, 2.500 e $4.000 \mathrm{~kg} \mathrm{MSV/ha,} \mathrm{respectivamente,} \mathrm{de} \mathrm{resíduo} \mathrm{pós-pastejo.}$

* Médias seguidas pela mesma letra na coluna não são diferentes ( $p>0.05)$ pelo teste de Tukey.

Observa-se, nas Tabelas 22, 23 e 24, que a intensidade de pastejo influenciou no consumo de nutrientes, ocorrendo aumento do consumo com o aumento da intensidade de pastejo. Para $\mathrm{P}$ e $\mathrm{K}$, as diferenças ocorreram entre as três intensidades; para $\mathrm{N}, \mathrm{Mg}$ e $\mathrm{S}$, apenas o tratamento de alta intensidade foi diferente dos demais. As diferenças de consumo de $\mathrm{N}$ e Mg (Tabelas $22 \mathrm{e}$ 24) foram maiores no período 03 para intensidade alta em relação às demais intensidades de pastejo. Já para $\mathrm{Ca}$, a intensidade de pastejo não teve efeito em seu consumo.

O consumo animal de minerais por meio do pastejo foi calculado a partir dos dados de taxa de lotação (UA/ha), consumo animal de forragem (kg $\mathrm{MS} / 100 \mathrm{~kg} \mathrm{PV})$ e concentração dos minerais no pastejo simulado $(\mathrm{g} / \mathrm{kg})$. Deste modo, qualquer destas variáveis influencia diretamente o consumo animal de minerais.

Neste sentido, houve efeito da intensidade de pastejo na taxa de lotação, sendo 6,5, 5,2 e 4,1 UA/ha, respectivamente para os tratamentos de alta, média e baixa intensidade de pastejo (Penati, 2002). Observa-se que a taxa de lotação aumenta com a intensidade de pastejo. De maneira contrária, o consumo médio de forragem no tratamento de alta intensidade de pastejo foi menor - 65,3 g MO/kg PM (g de matéria orgânica/kg de peso metabólico) - quando comparado 
ao verificado nos outros tratamentos. Por outro lado, os consumos nos tratamentos de média e baixa intensidade de pastejo foram semelhantes e iguais a 73,6 e 74,2 g MO/kg PM, respectivamente (Balsalobre, 2002). Com relação às concentrações de minerais no pastejo simulado, observa-se, na Tabela 21, que não foram influenciadas pela intensidade de pastejo. Assim, analisando os dados relativos a taxa de lotação, consumo de forragem e concentração de minerais no pastejo simulado, conclui-se que a variável que determinou as diferenças de consumo animal de minerais (Tabelas 22, 23 e 24) foi a taxa de lotação.

Tabela 24. Estimativa do consumo animal de magnésio $\left(\mathrm{kg}^{\star} \mathrm{ha}^{-1 *} \mathrm{Ciclo}^{-2}\right)$ em capim Tanzânia irrigado em função dos períodos de coletas e das intensidades de pastejo

\begin{tabular}{cccc}
\hline \multirow{2}{*}{ Período de coleta } & Alta & $\begin{array}{c}\text { Intensidade de pastejo } \\
\text { Média }\end{array}$ & Baixa \\
\hline 01 & $6,2 \mathrm{aA}$ & $6,3 \mathrm{aA}$ & $5,5 \mathrm{aA}$ \\
02 & $6,3 \mathrm{aA}$ & $5,6 \mathrm{aA}$ & $4,4 \mathrm{aA}$ \\
03 & $8,3 \mathrm{aA}$ & $5,9 \mathrm{aB}$ & $4,7 \mathrm{aB}$
\end{tabular}

P1 - 30/10/1999 a 14/02/2000; P2 - 15/02/2000 a 01/06/2000; P3 - 02/06/2000 a 23/10/2000. Intensidade de pastejo alta, média e baixa - 1.000, 2.500 e $4.000 \mathrm{~kg}$ MSV/ha, respectivamente, de resíduo pós-pastejo. * Médias seguidas pela mesma letra (minúscula na coluna e maiúscula na linha) não são diferentes ( $p>0.05$ ) pelo teste de Tukey.

Os resultados apresentados nas Tabelas 22, 23 e 24 permitem estimar 0 requerimento de minerais nas adubações de pastagens manejadas em diferentes intensidades de pastejo, uma vez que se pode calcular o consumo total desses nutrientes durante os dez ciclos de pastejo. O consumo de minerais, em ordem decrescente, foi $339 \mathrm{~kg} \mathrm{~K}, 274 \mathrm{~kg} \mathrm{~N}, 50 \mathrm{~kg} \mathrm{Ca}, 48 \mathrm{~kg} \mathrm{Mg} \mathrm{e}$ $26 \mathrm{~kg} \mathrm{P}$ e $16 \mathrm{~kg} \mathrm{~S}$ por hectare por ano no tratamento de baixa intensidade, e $541 \mathrm{~kg} \mathrm{~K}, 397 \mathrm{~kg} \mathrm{~N}, 61 \mathrm{~kg} \mathrm{Ca}, 69 \mathrm{~kg} \mathrm{Mg}, 40 \mathrm{~kg} \mathrm{P}$ e $26 \mathrm{~kg} \mathrm{~S} \mathrm{ha}^{-1 *}$ ano $^{-2}$ no tratamento de alta intensidade de pastejo. Desta forma, essas diferenças entre consumo de minerais de acordo com a intensidade de pastejo podem 
determinar diferenças nas adubações de reposição. Por outro lado, como já discutido, a reciclagem de nutrientes tem grande importância na dinâmica desses elementos no sistema solo-planta-animal, tornando-se importante o conhecimento das vias de entrada, saída e ciclagem dos nutrientes, para que sejam traçadas estratégias de adubação visando a fornecer o suprimento adequado de cada nutriente. Neste sentido, os nutrientes contidos no material vegetal depositado no solo e nas excretas dos animais são importantes fontes de reciclagem de nutrientes no sistema.

A Tabela 25 demonstra o retorno de nitrogênio, fósforo, potássio, cálcio, magnésio e enxofre via excremento animal em função das intensidades de pastejo. Do mesmo modo, a Tabela 26 compila os dados de porcentagem de nitrogênio, fósforo, potássio, cálcio, magnésio e enxofre que retornaram ao solo via excremento animal em relação ao total de nutriente contido na massa de forragem pré-pastejo.

Tabela 25. Retorno estimado de nitrogênio, fósforo, potássio, cálcio e enxofre via excremento (fezes e urina) animal em função das intensidades de pastejo por ciclo de pastejo

\begin{tabular}{ccccccc}
\hline Intensidade & \multicolumn{5}{c}{ Minerais $\left(\mathrm{kg}^{\star} \mathrm{ha}^{-1} \text { Ciclo }^{-2}\right)^{*}$} \\
de pastejo & Nitrogênio & Fósforo & Potássio & Cálcio & Magnésio & Enxofre \\
\hline Alta & $33,8 \mathrm{a}$ & $2,9 \mathrm{a}$ & $53,9 \mathrm{a}$ & $4,1 \mathrm{a}$ & $6,4 \mathrm{a}$ & $2,3 \mathrm{a}$ \\
Média & $27,4 \mathrm{~b}$ & $2,3 \mathrm{~b}$ & $42,2 \mathrm{~b}$ & $3,9 \mathrm{a}$ & $5,8 \mathrm{ab}$ & $1,9 \mathrm{ab}$ \\
Baixa & $23,1 \mathrm{~b}$ & $1,7 \mathrm{c}$ & $33,0 \mathrm{~b}$ & $3,3 \mathrm{a}$ & $4,7 \mathrm{~b}$ & $1,6 \mathrm{~b}$ \\
\hline
\end{tabular}

Intensidade de pastejo alta, média e baixa - 1.000, 2.500 e $4.000 \mathrm{~kg} \mathrm{MSV/ha,} \mathrm{respectivamente,} \mathrm{de} \mathrm{resíduo} \mathrm{pós-pastejo.}$ * Médias seguidas pela mesma letra na coluna não são diferentes ( $p>0.05)$ pelo teste de Tukey.

Observa-se, na Tabela 25, que uma maior quantidade de minerais retorna ao solo via excremento animal nos tratamentos de alta intensidade de pastejo, exceção feita ao Ca. Segundo Barrow (1987), 60 a 99\% dos nutrientes ingeridos retornam ao pasto na forma de excreta. Desta maneira, a quantidade de nutrientes removidos pelos animais por meio do pastejo, proporcionando 
ganhos, e dessa forma exportados do sistema, é baixa. Sendo assim, o comportamento do retorno de minerais via excrementos deve ser semelhante ao observado no consumo desses minerais pelos bovinos, como demonstrado nas Tabelas 22, 23 e 24 e, do mesmo modo, influenciado pela taxa de lotação. No presente estudo, as porcentagens de minerais ingeridos que retornaram ao pasto na forma de excreta foram 88, 71, 99, 68, 99 e 90\%, respectivamente para $\mathrm{N}, \mathrm{P}, \mathrm{K}, \mathrm{Ca}, \mathrm{Mg}$ e $\mathrm{S}$, demonstrando similaridade com os dados apresentados por Barrow (1987).

A Tabela 26 demonstra o retorno dos minerais via excrementos em relação ao total de minerais na massa de forragem pré-pastejo. Observa-se que uma maior porcentagem dos minerais contidos na forrageira retorna ao solo via excreções quando a pastagem é manejada com alta intensidade, obtendo valores ao redor de $49 \%$ para N e S, cerca de $46 \%$ para Mg e perto de 30,33 e $35 \%$ para $\mathrm{P}$, Ca e $\mathrm{K}$, respectivamente.

Por outro lado, quando a pastagem é manejada com baixa intensidade, uma menor proporção dos minerais contidos na forragem retorna ao solo via excrementos em aproximadamente $21 \%$ para $\mathrm{N}$ e S, 18\% para Mg e 10, 12 e $15 \%$ para $\mathrm{P}, \mathrm{K}$ e $\mathrm{Ca}$, respectivamente.

Tabela 26. Retorno estimado de nitrogênio, fósforo, potássio, cálcio e enxofre via excremento animal em relação ao total de nutrientes na massa seca pré-pastejo em função das intensidades de pastejo

\begin{tabular}{ccccccc}
\hline Intensidade & & \multicolumn{5}{c}{ Minerais (\%) * } \\
de pastejo & Nitrogênio & Fósforo & Potássio & Cálcio & Magnésio & Enxofre \\
\hline Alta & $49,5 \mathrm{a}$ & $30,2 \mathrm{a}$ & $35,4 \mathrm{a}$ & $33,4 \mathrm{a}$ & $45,9 \mathrm{a}$ & $49,4 \mathrm{a}$ \\
Média & $27,7 \mathrm{~b}$ & $14,7 \mathrm{~b}$ & $18,2 \mathrm{~b}$ & $18,9 \mathrm{~b}$ & $24,8 \mathrm{~b}$ & $25,5 \mathrm{~b}$ \\
Baixa & $21,4 \mathrm{~b}$ & $10,1 \mathrm{~b}$ & $12,6 \mathrm{~b}$ & $14,9 \mathrm{~b}$ & $18,3 \mathrm{~b}$ & $20,9 \mathrm{~b}$
\end{tabular}

Intensidade de pastejo alta, média e baixa - 1.000, 2.500 e $4.000 \mathrm{~kg}$ MSV/ha, respectivamente, de resíduo pós-pastejo. * Médias seguidas pela mesma letra na coluna não são diferentes $(p>0.05)$ pelo teste de Tukey. 
Mays et al. (1980) demonstraram o efeito da utilização da forragem na reciclagem de fósforo via excreta animal ou resíduo da planta, indicando que a mudança nas vias de reciclagem ocorre de acordo com o grau de utilização da forragem. Quando se utilizam apenas $25 \%$ da forragem, $75 \%$ do P contido na forragem retornam ao solo via planta. Por outro lado, a utilização de $75 \%$ da forragem determina um retorno de $66 \%$ do $\mathrm{P}$ contido na forragem via fezes. Assim, à medida que se intensifica o sistema de produção, por exemplo, por meio do aumento da taxa de lotação, aumenta a proporção de forragem consumida, elevando a importância da excreta em relação ao material vegetal depositado no solo no retorno dos nutrientes a este.

Neste sentido, a diferença entre a disponibilidade e a perda de minerais contidos na liteira e nos excrementos animais determina que os tratamentos que retornam maior quantidade dos minerais via excreta (alta intensidade de pastejo), ao mesmo tempo em que disponibilizam maior quantidade desses minerais à planta, também estão sujeitos a maiores possibilidades de perdas. Por outro lado, os tratamentos que retornam menor quantidade de minerais via excreta (média e baixa intensidade) retornam maior quantidade de minerais via planta por meio de processos de senescência e perdas de forragem por danos físicos decorrentes do pisoteio. Esses tipos de perdas de forragem podem gerar benefícios a esses tratamentos, pois, como revisado, a reciclagem via planta tem melhor distribuição espacial na pastagem e possibilita menores perdas dos minerais.

Neste sentido, segundo Mott (1974), a porcentagem de minerais reciclada via planta depende, primeiramente, da quantidade de forragem utilizada pelos animais, bem como da composição química das partes das plantas consumidas pelo animal.

A quantidade de forragem utilizada é função, por exemplo, da carga animal empregada, tendo Penati (2002) obtido eficiências de pastejo de 47, 67 e $75 \%$ com taxas de lotação equivalentes a 4,1, 5,2 e 6,5 UA/ha, respectivamente. Do mesmo modo, Caminha et al. (2002) obtiveram eficiência 
de pastejo em capim Marandu, em lotação contínua, manejado a 40, 30, 20 e $10 \mathrm{~cm}$ de altura, de 68, 69, 76 e 82\%, respectivamente. Santos (2002) demonstrou existir maior renovação da população de perfilhos nas áreas submetidas a alta intensidade de pastejo. Esses aspectos reforçam a hipótese de ocorrer maior reciclagem de minerais via planta nos tratamentos de média e baixa intensidade de pastejo.

Com relação aos danos físicos por pisoteio, Quadros et al. (2001) encontraram valores de perdas de até $14 \%$ da forragem disponível pré-pastejo, para o capim Mombaça, quando submetido aos níveis mais altos de adubação, sendo os valores médios ao redor de 7\%. Tosi (1999), em pastagem adubada de capim Tanzânia sob lotação intermitente, teve perdas anuais de $1.050 \mathrm{~kg}$ MS/ha por ciclo de pastejo, correspondendo a $28 \%$ da massa de forragem prépastejo. Seguindo a tendência apresentada, neste experimento, a quantidade de forragem perdida em função dos tratamentos foi $624,1.175$ e $1.720 \mathrm{~kg}$ de massa seca por hectare por ciclo, respectivamente nos tratamentos de alta, média e baixa intensidade de pastejo (Penati, 2002). Dessa maneira, possivelmente uma maior quantidade de minerais deve ter retornado ao solo a partir das perdas de forragem por pisoteio e senescência nos tratamentos com menor intensidade de pastejo.

Por outro lado, segundo Barbosa (1999), a concentração de minerais no material depositado sobre o solo é função da disponibilidade de nutrientes para as plantas. Sendo alta, a planta forrageira perdida por meio de pastejo terá composição favorável de nutrientes, a qual determinará rápida mineralização. 0 total de material depositado no solo devido às perdas de pastejo durante os dez ciclos foi $6.240,11.750$ e $17.200 \mathrm{~kg}$ de $\mathrm{MS} / \mathrm{ha}$, respectivamente para os tratamentos de alta, média e baixa intensidade. Entretanto, ao final deste experimento, foi estimada a quantidade de material sobre o solo, sendo 1.124, 1.717 e $1.973 \mathrm{~kg} \mathrm{MS} / \mathrm{ha}$, ou seja, a cada ciclo, o material depositado sobre o solo é decomposto, uma vez que cada ciclo acumula $624,1.175$ e $1.720 \mathrm{~kg}$ de MS/ha/ciclo. Assim, 82, 86 e $89 \%$ da massa de forragem acumulada sobre 0 
solo durante os dez ciclos de pastejo, respectivamente para os tratamentos de alta, média e baixa intensidade de pastejo, foram decompostos, demonstrando a boa qualidade do material vegetal depositado sobre o solo.

\subsection{Cálculo e validação das normas DRIS}

A Tabela 27 contém os valores do acúmulo de massa seca, da concentração dos nutrientes e seus respectivos desvios-padrão e coeficientes de variação. Observa-se, ao analisar os dados das 177 amostras iniciais, uma grande variação do acúmulo de massa seca, demonstrada pelo alto coeficiente de variação (101\%). Este fato deve estar relacionado às alterações climáticas durante o período experimental. Neste sentido, a seleção das amostras para compor o grupo de dados que deram origem à população de referência (43 amostras) apresenta sensível redução desse coeficiente. 
Tabela 27. Acúmulo de massa seca, concentração dos macro e micronutrientes nas LFRE, desvio-padrão e coeficiente de variação em função da produção média para seleção da população de referência

\begin{tabular}{|c|c|c|c|c|c|c|c|c|c|c|c|c|c|}
\hline $\begin{array}{l}\text { Corte }^{*} \\
\text { (kg/ha) }\end{array}$ & & $\begin{array}{c}\text { Acúmulo } \\
\text { (kg/ha) }\end{array}$ & $\mathbf{N}$ & $\mathbf{P}$ & K & $\mathrm{Ca}$ & $\mathrm{Mg}$ & $\mathbf{S}$ & $\mathrm{Fe}$ & $\mathrm{Mn}$ & Zn & $\mathrm{Cu}$ & B \\
\hline Todas & Média & 2,76 & 21,9 & 2,6 & 26,7 & 5,2 & 3,7 & 1,4 & 288 & 133 & 24,5 & 11,9 & 7,8 \\
\hline \multirow[t]{2}{*}{177 ** } & $S$ & 2,79 & 5,12 & 0,58 & 4,65 & 1,32 & 1,16 & 0,32 & 185 & 76 & 4,87 & 4,46 & 2,38 \\
\hline & C.V\% & 101,0 & 23,3 & 22,8 & 17,4 & 25,4 & 31,5 & 22,0 & 64 & 57 & 19,9 & 37,5 & 30,5 \\
\hline 1.000 & Média & 4,10 & 20,6 & 2,5 & 26,5 & 4,9 & 3,5 & 1,4 & 259 & 124 & 24,2 & 12,0 & 8,1 \\
\hline \multirow[t]{2}{*}{115 ** } & $S$ & 2,2 & 4,5 & 0,6 & 4,0 & 1,2 & 1,0 & 0,3 & 140 & 71 & 5,2 & 4,5 & 2,5 \\
\hline & C.V\% & 54,11 & 21,8 & 24,5 & 15,0 & 24,5 & 29,5 & 23,5 & 54,0 & 57,4 & 21,4 & 37,7 & 30,7 \\
\hline 2.298 & Média & 4,92 & 19,7 & 2,4 & 26,2 & 4,9 & 3,3 & 1,3 & 269 & 119 & 24,2 & 11,4 & 8,4 \\
\hline \multirow[t]{2}{*}{90 ** } & $S$ & 1,9 & 3,64 & 0,57 & 3,99 & 1,17 & 0,86 & 0,28 & 201 & 66 & 5,31 & 4,75 & 2,64 \\
\hline & C.V\% & 40,48 & 18,5 & 23,7 & 15,2 & 23,6 & 26,1 & 21,3 & 75 & 55 & 22,0 & 41,5 & 31,5 \\
\hline Norma & Média & 5,19 & 19,4 & 2,3 & 26,1 & 5,0 & 3,4 & 1,3 & 219 & 122 & 25,1 & 12,7 & 9,5 \\
\hline \multirow[t]{2}{*}{$43^{* *}$} & $S$ & 2,0 & 3,2 & 0,4 & 4,0 & 1,1 & 0,6 & 0,2 & 104 & 55 & 4,6 & 4,6 & 2,3 \\
\hline & C.V\% & 38,76 & 16,5 & 17,3 & 15,4 & 21,6 & 17,7 & 19,1 & 47 & 45 & 18,3 & 36,0 & 23,7 \\
\hline
\end{tabular}

* Massa de forragem referente ao ponto de separação das amostras entre a subpopulação de alta produção e a subpopulação de baixa produção.

** Número de amostras que compõe cada grupo.

Com relação às outras determinações contidas na Tabela 27, observa-se que a população inicial de dados já apresentava um baixo coeficiente de variação para os nutrientes, exceção feita ao ferro e ao manganês. Mesmo assim, observam-se melhoras nas determinações do coeficiente de variação e desvio-padrão à medida que se selecionam dados que apresentam maior acúmulo de massa seca, demonstrando que populações que apresentam alta produtividade têm maior homogeneidade nas concentrações dos nutrientes.

No trabalho realizado por Bailey et al. (1997), para estabelecer as normas DRIS para Azevém perene, na Irlanda do Norte, os coeficientes de variação na população de referência foram 43, 41, 53, 34, 45 e 41\%, respectivamente para $\mathrm{N}, \mathrm{P}, \mathrm{K}, \mathrm{Ca}, \mathrm{Mg}$ e $\mathrm{S}$, sendo as médias da concentração 
dos nutrientes, nessa mesma ordem, 21, 3, 23, 10, 3 e $3 \mathrm{~g} / \mathrm{kg}$ MS. Do mesmo modo, Silveira et al. (2003) obtiveram os coeficientes de variação, na população de referência, 22, 29, 38, 69, 41, 43, 57, 39, 47 e 50\%, respectivamente para $N$, $\mathrm{P}, \mathrm{K}, \mathrm{Ca}, \mathrm{Mg}, \mathrm{S}, \mathrm{Cu}, \mathrm{Fe}, \mathrm{Mn}$ e $\mathrm{Zn}$, sendo as concentrações médias para esses nutrientes, na mesma ordem, 20,2, 2,0, 20,5, 4,2, 2,0, 1,5 g/kg MS e 5,8, 107, $25,14,8 \mathrm{mg} / \mathrm{kg} \mathrm{MS}$, em estudo para determinar as normas DRIS para Brachiaria decumbens, utilizando dados de experimentos realizados em casa de vegetação. Em trabalho realizado por Walworth et al. (1988), na geração de normas DRIS para milho, as médias das concentrações de $\mathrm{N}, \mathrm{P}, \mathrm{K}, \mathrm{Ca}, \mathrm{Mg}$ da população que compôs a norma DRIS foram 32,5, 4,2, 23,0, 5,3, 1,4 g/kg MS e 140, 40, 10 e 14 mg/kg MS, respectivamente para Fe, Mn, Cu e B. Creste \& Nakagawa (1997) estabeleceram normas DRIS para a cultura do limoeiro. Nesse estudo, os coeficientes de variação foram 10, 46, 10, 24, 9, 13, 12, 85, 37, 19 e 68\%, respectivamente para as concentrações de N, P, K, Ca, Mg, S, B, $\mathrm{Cu}, \mathrm{Fe}, \mathrm{Mn}$ e Zn. Desse modo, verifica-se que os C.V. para os micronutrientes são maiores, demonstrando existir maior faixa de variação para esses nutrientes nas populações de referência, o que pode indicar maior amplitude de variação da concentração dos micronutrientes sem alterar a produção da planta forrageira.

Com relação às médias das concentrações dos nutrientes na LFRE que compõem a população de referência, podem ser comparadas aos valores obtidos nos trabalhos apresentados e aos valores de nível crítico estabelecidos para Panicum maximum. Neste sentido, essas comparações já foram realizadas em tópicos anteriores, quando apresentados os resultados e discutidos os efeitos dos períodos de coleta e intensidade de pastejo nas concentrações dos nutrientes. Conclui-se, dos estudos apresentados, que, na maioria dos períodos e tratamentos, essas concentrações foram semelhantes ou maiores que os níveis críticos estabelecidos para essa forrageira. Sendo assim, provavelmente, as concentrações apresentadas na Tabela 27 são condizentes com o bom estado nutricional da forrageira. 
As normas DRIS para Panicum maximum cV. Tanzânia são apresentadas nas Tabelas 28 e 29, com base na média, no coeficiente de variação e no desvio-padrão das relações diretas e inversas dos nutrientes estudados, possibilitando, dessa forma, o cálculo dos índices DRIS a partir dos métodos propostos por Beaufils (1973), Jones (1981) e Elwali \& Gascho (1984). 
Tabela 28. Normas DRIS (média, coeficiente de variação e desvio-padrão) para capim Tanzânia para os pares dos macro e micronutrientes

\begin{tabular}{|c|c|c|c|c|c|c|c|}
\hline Relações & Média & C. V \% * & $S^{* *}$ & Relações & Média & C. V\% * & $S^{* *}$ \\
\hline $\mathrm{N} / \mathrm{P}$ & 8,75 & 25,1 & 2,198 & $\mathrm{Ca} / \mathrm{N}$ & 0,27 & 21,0 & 0,057 \\
\hline $\mathrm{N} / \mathrm{K}$ & 0,73 & 23,5 & 0,171 & $\mathrm{Ca} / \mathrm{P}$ & 2,26 & 26,5 & 0,597 \\
\hline $\mathrm{N} / \mathrm{Ca}$ & 3,97 & 23,3 & 0,927 & $\mathrm{Ca} / \mathrm{K}$ & 0,20 & 30,9 & 0,061 \\
\hline N/Mg & 6,17 & 23,2 & 1,429 & $\mathrm{Ca} / \mathrm{Mg}$ & 1,65 & 27,0 & 0,444 \\
\hline $\mathrm{N} / \mathrm{S}$ & 14,71 & 15,4 & 2,262 & $\mathrm{Ca} / \mathrm{S}$ & 3,95 & 28,4 & 1,124 \\
\hline $\mathrm{N} / \mathrm{Fe}$ & 0,10 & 54,1 & 0,053 & $\mathrm{Ca} / \mathrm{Fe}$ & 0,03 & 60,0 & 0,016 \\
\hline $\mathrm{N} / \mathrm{Mn}$ & 0,19 & 39,5 & 0,075 & $\mathrm{Ca} / \mathrm{Mn}$ & 0,05 & 40,7 & 0,020 \\
\hline$N / Z n$ & 0,81 & 20,0 & 0,162 & $\mathrm{Ca} / \mathrm{Zn}$ & 0,22 & 24,5 & 0,053 \\
\hline $\mathrm{N} / \mathrm{Cu}$ & 2,07 & 39,0 & 0,808 & $\mathrm{Ca} / \mathrm{Cu}$ & 0,57 & 42,9 & 0,246 \\
\hline N/B & 2,40 & 31,2 & 0,749 & $\mathrm{Ca} / \mathrm{B}$ & 0,64 & 29,3 & 0,188 \\
\hline $\mathrm{P} / \mathrm{N}$ & 0,13 & 21,4 & 0,027 & $\mathrm{Mg} / \mathrm{N}$ & 0,17 & 22,4 & 0,039 \\
\hline $\mathrm{P} / \mathrm{K}$ & 0,09 & 24,5 & 0,022 & $\mathrm{Mg} / \mathrm{P}$ & 1,45 & 28,6 & 0,415 \\
\hline $\mathrm{P} / \mathrm{Ca}$ & 0,49 & 25,1 & 0,123 & $\mathrm{Mg} / \mathrm{K}$ & 0,12 & 23,9 & 0,029 \\
\hline $\mathrm{P} / \mathrm{Mg}$ & 0,77 & 26,4 & 0,202 & $\mathrm{Mg} / \mathrm{Ca}$ & 0,68 & 29,3 & 0,198 \\
\hline $\mathrm{P} / \mathrm{S}$ & 1,86 & 29,8 & 0,553 & $\mathrm{Mg} / \mathrm{S}$ & 2,53 & 21,7 & 0,550 \\
\hline $\mathrm{P} / \mathrm{Fe}$ & 0,01 & 67,4 & 0,009 & $\mathrm{Mg} / \mathrm{Fe}$ & 0,02 & 61,2 & 0,010 \\
\hline $\mathrm{P} / \mathrm{Mn}$ & 0,02 & 44,4 & 0,010 & $\mathrm{Mg} / \mathrm{Mn}$ & 0,03 & 45,3 & 0,015 \\
\hline $\mathrm{P} / \mathrm{Zn}$ & 0,10 & 24,0 & 0,024 & $\mathrm{Mg} / \mathrm{Zn}$ & 0,14 & 23,5 & 0,032 \\
\hline $\mathrm{P} / \mathrm{Cu}$ & 0,25 & 34,8 & 0,087 & $\mathrm{Mg} / \mathrm{Cu}$ & 0,33 & 33,7 & 0,112 \\
\hline P/B & 0,30 & 21,4 & 0,063 & $\mathrm{Mg} / \mathrm{B}$ & 0,40 & 25,7 & 0,102 \\
\hline $\mathrm{K} / \mathrm{N}$ & 1,46 & 21,7 & 0,317 & $\mathrm{~S} / \mathrm{N}$ & 0,07 & 15,7 & 0,011 \\
\hline $\mathrm{K} / \mathrm{P}$ & 12,27 & 24,6 & 3,020 & $S / P$ & 0,60 & 26,8 & 0,161 \\
\hline $\mathrm{K} / \mathrm{Ca}$ & 5,80 & 27,7 & 1,603 & $S / K$ & 0,05 & 20,9 & 0,011 \\
\hline $\mathrm{K} / \mathrm{Mg}$ & 8,72 & 19,2 & 1,671 & $\mathrm{~S} / \mathrm{Ca}$ & 0,28 & 25,2 & 0,069 \\
\hline $\mathrm{K} / \mathrm{S}$ & 21,31 & 19,4 & 4,126 & $\mathrm{~S} / \mathrm{Mg}$ & 0,44 & 21,9 & 0,096 \\
\hline $\mathrm{K} / \mathrm{Fe}$ & 0,14 & 56,3 & 0,078 & $\mathrm{~S} / \mathrm{Fe}$ & 0,01 & 47,7 & 0,003 \\
\hline $\mathrm{K} / \mathrm{Mn}$ & 0,27 & 33,4 & 0,090 & $\mathrm{~S} / \mathrm{Mn}$ & 0,01 & 35,4 & 0,005 \\
\hline $\mathrm{K} / \mathrm{Zn}$ & 1,14 & 17,7 & 0,202 & $S / Z n$ & 0,06 & 14,7 & 0,008 \\
\hline $\mathrm{K} / \mathrm{Cu}$ & 2,90 & 32,6 & 0,945 & $\mathrm{~S} / \mathrm{Cu}$ & 0,15 & 33,6 & 0,050 \\
\hline $\mathrm{K} / \mathrm{B}$ & 3,40 & 26,5 & 0,902 & S/B & 0,17 & 31,4 & 0,054 \\
\hline
\end{tabular}


Tabela 29. Normas DRIS (média, coeficiente de variação e desvio-padrão) para capim Tanzânia para os pares dos macro e micronutrientes

\begin{tabular}{|c|c|c|c|c|c|c|c|}
\hline Relações & Média & C. V \% * & $S$ ** & Relações & Média & C. V\% \% & $S$ ** \\
\hline $\mathrm{Fe} / \mathrm{N}$ & 13,46 & 40,7 & 5,474 & $\mathrm{Zn} / \mathrm{S}$ & 18,84 & 16,3 & 3,075 \\
\hline $\mathrm{Fe} / \mathrm{P}$ & 118,34 & 49,8 & 58,983 & $\mathrm{Zn} / \mathrm{Fe}$ & 0,12 & 54,9 & 0,069 \\
\hline $\mathrm{Fe} / \mathrm{K}$ & 9,05 & 42,2 & 3,815 & $\mathrm{Zn} / \mathrm{Mn}$ & 0,24 & 37,3 & 0,089 \\
\hline $\mathrm{Fe} / \mathrm{Ca}$ & 53,73 & 44,6 & 23,949 & $\mathrm{Zn} / \mathrm{Cu}$ & 2,52 & 32,5 & 0,821 \\
\hline $\mathrm{Fe} / \mathrm{Mg}$ & 77,81 & 37,3 & 29,047 & $\mathrm{Zn} / \mathrm{B}$ & 3,00 & 32,7 & 0,978 \\
\hline $\mathrm{Fe} / \mathrm{S}$ & 188,06 & 37,2 & 69,947 & $\mathrm{Cu} / \mathrm{N}$ & 0,63 & 45,1 & 0,283 \\
\hline $\mathrm{Fe} / \mathrm{Mn}$ & 2,51 & 49,3 & 1,239 & $\mathrm{Cu} / \mathrm{P}$ & 5,13 & 50,4 & 2,586 \\
\hline $\mathrm{Fe} / \mathrm{Zn}$ & 10,24 & 36,2 & 3,708 & $\mathrm{Cu} / \mathrm{K}$ & 0,42 & 38,5 & 0,163 \\
\hline $\mathrm{Fe} / \mathrm{Cu}$ & 26,63 & 50,7 & 13,488 & $\mathrm{Cu} / \mathrm{Ca}$ & 2,53 & 50,3 & 1,273 \\
\hline $\mathrm{Fe} / \mathrm{B}$ & 31,85 & 47,5 & 15,129 & $\mathrm{Cu} / \mathrm{Mg}$ & 3,58 & 37,9 & 1,359 \\
\hline $\mathrm{Mn} / \mathrm{N}$ & 6,41 & 49,3 & 3,164 & $\mathrm{Cu} / \mathrm{S}$ & 9,26 & 44,9 & 4,162 \\
\hline $\mathrm{Mn} / \mathrm{P}$ & 51,52 & 47,2 & 24,301 & $\mathrm{Cu} / \mathrm{Fe}$ & 0,06 & 68,3 & 0,042 \\
\hline $\mathrm{Mn} / \mathrm{K}$ & 4,48 & 49,9 & 2,239 & $\mathrm{Cu} / \mathrm{Mn}$ & 0,12 & 56,0 & 0,066 \\
\hline $\mathrm{Mn} / \mathrm{Ca}$ & 25,11 & 54,9 & 13,796 & $\mathrm{Cu} / \mathrm{Zn}$ & 0,47 & 34,9 & 0,164 \\
\hline $\mathrm{Mn} / \mathrm{Mg}$ & 39,61 & 56,4 & 22,329 & $\mathrm{Cu} / \mathrm{B}$ & 1,35 & 44,7 & 0,604 \\
\hline $\mathrm{Mn} / \mathrm{S}$ & 93,94 & 52,8 & 49,636 & $\mathrm{~B} / \mathrm{N}$ & 0,48 & 32,2 & 0,155 \\
\hline $\mathrm{Mn} / \mathrm{Fe}$ & 0,65 & 93,6 & 0,609 & $\mathrm{~B} / \mathrm{P}$ & 3,99 & 28,2 & 1,127 \\
\hline $\mathrm{Mn} / \mathrm{Zn}$ & 5,03 & 45,8 & 2,305 & $\mathrm{~B} / \mathrm{K}$ & 0,34 & 38,1 & 0,130 \\
\hline $\mathrm{Mn} / \mathrm{Cu}$ & 13,37 & 60,5 & 8,083 & $\mathrm{~B} / \mathrm{Ca}$ & 1,86 & 34,5 & 0,644 \\
\hline $\mathrm{Mn} / \mathrm{B}$ & 15,34 & 47,9 & 7,339 & $\mathrm{~B} / \mathrm{Mg}$ & 2,86 & 29,2 & 0,834 \\
\hline $\mathrm{Zn} / \mathrm{N}$ & 1,30 & 21,8 & 0,284 & $B / S$ & 7,26 & 41,3 & 3,000 \\
\hline $\mathrm{Zn} / \mathrm{P}$ & 10,81 & 26,3 & 2,845 & $\mathrm{~B} / \mathrm{Fe}$ & 0,05 & 82,0 & 0,041 \\
\hline $\mathrm{Zn} / \mathrm{K}$ & 0,91 & 21,7 & 0,198 & $\mathrm{~B} / \mathrm{Mn}$ & 0,09 & 52,0 & 0,047 \\
\hline $\mathrm{Zn} / \mathrm{Ca}$ & 5,07 & 24,9 & 1,265 & $\mathrm{~B} / \mathrm{Zn}$ & 0,38 & 37,3 & 0,141 \\
\hline $\mathrm{Zn} / \mathrm{Mg}$ & 7,73 & 23,1 & 1,786 & $\mathrm{~B} / \mathrm{Cu}$ & 0,90 & 39,7 & 0,359 \\
\hline
\end{tabular}


Após a determinação das normas DRIS, foram realizados os cálculos dos índices DRIS com base nos métodos propostos por Beaufils (1973), Jones (1981) e Elwali \& Gascho (1984) para todas as amostras (177) do banco de dados dos experimentos do primeiro e do segundo ano experimental. A análise de regressão foi usada para ajustar um modelo que relacionasse índice DRIS com concentração de minerais, esta última como variável independente. O melhor ajuste foi o modelo linear $(y=a+b x)$.

Os modelos estatísticos entre as concentrações foliares dos minerais e os respectivos índices DRIS são apresentados nas Figuras 5 e 6 . Todos os índices DRIS aumentaram com suas respectivas concentrações de minerais.

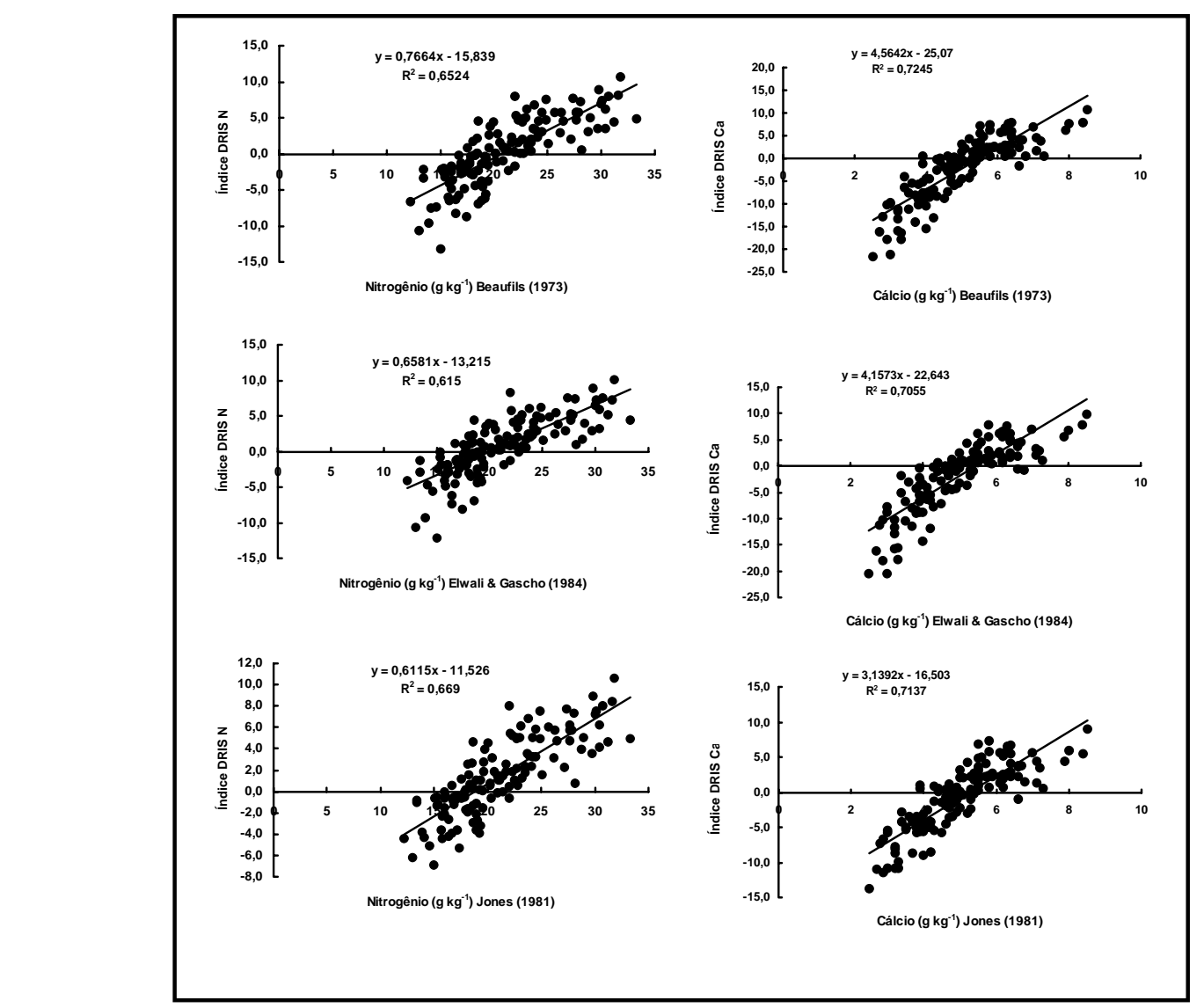

Figura 5 - Regressões entre índices DRIS, gerados a partir das funções calculadas pelos métodos propostos por Beaufils (1973), Jones (1981) e Elwali \& Gascho (1984), e a concentração de nitrogênio e cálcio (g/kg MS), para capim Tanzânia 

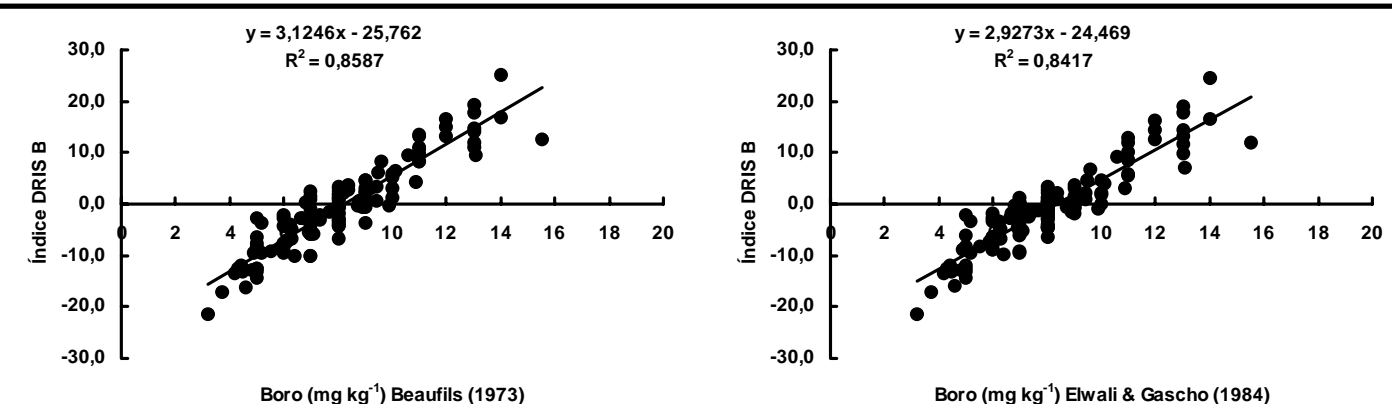

Boro $\left(\mathrm{mg} \mathrm{kg}^{-1}\right)$ Elwali \& Gascho (1984)

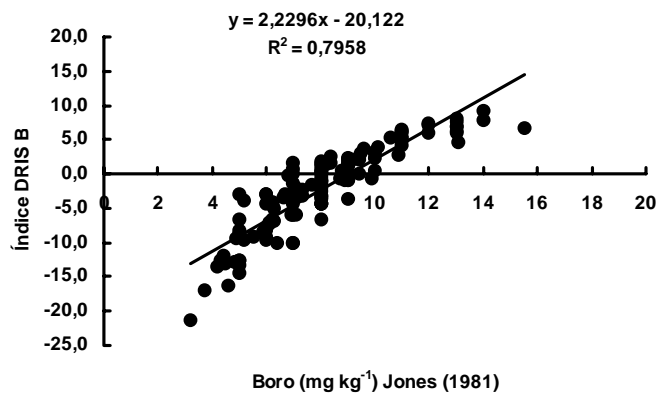

Figura 6 - Regressões entre índices DRIS, gerados a partir das funções calculadas pelos métodos propostos por Beaufils (1973), Jones (1981) e Elwali \& Gascho (1984), e a concentração de Boro (mg/kg MS), para capim Tanzânia

As Figuras 5 e 6 e a Tabela 30 demonstram que os coeficientes de determinação foram satisfatórios, exceção feita ao potássio e ao zinco, que apresentaram valores abaixo de 0,5, indicando menor relação entre os índices DRIS e a concentração desses nutrientes. Por outro lado, para todos os outros nutrientes, pode-se observar uma boa relação entre esses parâmetros. 
Tabela 30. Coeficiente de determinação entre os índices DRIS, gerados a partir das funções calculadas pelos métodos propostos por Beaufils (1973), Jones (1981) e Elwali \& Gascho (1984), e as concentrações dos macro e micronutrientes, para capim Tanzânia

\begin{tabular}{lccccccccccc}
\hline Método & $\mathrm{N}$ & $\mathrm{P}$ & $\mathrm{K}$ & $\mathrm{Ca}$ & $\mathrm{Mg}$ & $\mathrm{S}$ & $\mathrm{Fe}$ & $\mathrm{Mn}$ & $\mathrm{Zn}$ & $\mathrm{Cu}$ & $\mathrm{B}$ \\
& & - & - & - & - & - & - & - & \\
\hline Beaufils & 0,65 & 0,70 & 0,41 & 0,72 & 0,77 & 0,68 & 0,84 & 0,90 & 0,48 & 0,86 & 0,85 \\
$\begin{array}{l}\text { Elwali \& } \\
\text { Gascho }\end{array}$ & 0,61 & 0,68 & 0,39 & 0,70 & 0,74 & 0,64 & 0,77 & 0,88 & 0,46 & 0,82 & 0,84 \\
Jones & 0,67 & 0,71 & 0,38 & 0,71 & 0,79 & 0,68 & 0,82 & 0,84 & 0,46 & 0,81 & 0,79 \\
\hline
\end{tabular}

A correlação entre produtividade e concentração de minerais na planta é uma premissa para usar a análise de planta como critério de diagnose. Neste sentido, os índices DRIS podem ser usados para realizar a diagnose nutricional, no caso de existir uma correlação positiva entre concentração de minerais na planta e o índice DRIS desse mineral. Ao observar os modelos ajustados entre concentração foliares de minerais e os respectivos índices DRIS, constata-se que, em determinado ponto da reta, o índice DRIS torna-se nulo (Figuras 5 e 6). Nesse ponto, a concentração foliar não estaria limitando nutricionalmente a capacidade produtiva da forragem. Essa concentração é 20,6, 20,0 e 18,8 g/kg MS para nitrogênio, respectivamente para os métodos propostos por Beaufils (1973), Jones (1981) e Elwali \& Gascho (1984); 5,5, 5,4 e 5,2 g/kg MS para cálcio, nessa mesma ordem, e 8,2, 8,3 e 9,0 mg/kg MS para boro (Figuras 5 e $6)$.

Neste aspecto, os valores obtidos de nitrogênio estão próximos ao nível crítico de 21,4 g/kg MS, determinado por Abreu (1999), similar aos valores encontrados por Colozza (1998) - 20,8 e 22,9 g/kg MS, respectivamente no primeiro e segundo cortes -, e também ao valor de Hoffman et al. (1995) - 19,4 g/kg MS - para capim Colonião. Nos três experimentos apontados, a parte analisada foi a mesma caracterizada neste experimento como LFRE. 
Os valores obtidos de cálcio podem ser considerados adequados, visto, de acordo com Werner et al. (1979), a concentração de cálcio na parte aérea foi $4,2 \mathrm{~g} / \mathrm{kg} \mathrm{MS}$ no tratamento com o uso de calagem. Do mesmo modo, Faquin et al. (1997) determinaram as concentrações de cálcio na parte aérea de Brachiaria brizantha e Andropogom gayanus, obtendo valores de, respectivamente, 4,9 a 5,5, e 4,7 a 5,3 g/kg MS para essas espécies.

Os valores obtidos de boro foram os que se apresentaram mais próximos do nível crítico estabelecido por Malavolta et al. (1997) como adequado para a parte aérea de capim Colonião (7 a $10 \mathrm{mg} / \mathrm{kg} \mathrm{MS}$ ). Em revisão realizada por Monteiro et al. (2001), esses autores demonstraram que a faixa de suficiência para boro em gramíneas seria de 6 a $10 \mathrm{mg} / \mathrm{kg}$ MS.

Os outros nutrientes, de forma similar ao N, Ca e B, apresentaram valores de concentração, quando seu respectivo índice DRIS foi nulo, considerados adequados segundo revisão de literatura realizada.

Outro aspecto que pode ser observado na Tabela 30 relaciona-se aos métodos utilizados para cálculo das funções que deram origem aos índices DRIS para cada nutriente. Observa-se pouca variação entre os coeficientes de determinação referentes aos cálculos dos índices de cada método. Desta forma, a escolha do método não foi determinante para modificar as relações entre os índices DRIS e as concentrações dos nutrientes.

Com o objetivo de validar as normas DRIS estabelecidas, faz-se necessário o uso comparativo de dados experimentais independentes, de preferência de experimentos em que as diferenças em produtividade são obtidas em função da variação do nutriente estudado. Se os índices forem capazes de predizer a origem do comportamento observado no experimento, as normas serão válidas.

Neste sentido, foi utilizado para validar as normas DRIS para capim Tanzânia o trabalho realizado por Belarmino (2001), em que a autora determinou o rendimento e a qualidade do capim Tanzânia em função da aplicação de superfosfato simples e sulfato de amônio. Os tratamentos 
estabelecidos por Belarmino (2001) foram quatro doses de fósforo (0, 50, 100 e $150 \mathrm{~kg}$ de $\mathrm{P}_{2} \mathrm{O}_{5} / \mathrm{ha}$ ) aplicadas em uma única vez e três doses de nitrogênio ( 0 , 100 e $200 \mathrm{~kg}$ de N/ha) parceladas entre os cortes. A Tabela 31 demonstra os resultados de rendimento de massa seca, concentração dos macronutrientes na PT em função das doses de nitrogênio e fósforo determinadas por Belarmino (2001). O primeiro corte foi realizado 68 dias após o corte de uniformização; o segundo, 48 dias após o primeiro; e o terceiro, 48 dias após o segundo corte.

Tabela 31. Rendimento forrageiro (t MS/ha/corte) e concentração dos nutrientes na massa seca de capim Tanzânia (média do primeiro e segundo cortes), em função das doses de nitrogênio e fósforo

\begin{tabular}{cccccccccc}
\hline \multirow{2}{*}{$*$} & \multicolumn{2}{c}{ Doses (kg) } & $\begin{array}{c}\text { Produção } \\
\text { N }\end{array}$ & $\mathbf{N}$ & $\mathbf{P}$ & $\mathbf{K}$ & $\mathbf{C a}$ & $\mathbf{M g}$ & $\mathbf{S}$ \\
\hline 1 & 0 & 0 & 2,05 & 8,8 & 1,9 & 14,3 & 6,4 & 2,1 & 1,4 \\
2 & 0 & 50 & 2,22 & 8,8 & 2,1 & 14,2 & 6,7 & 2,2 & 1,4 \\
3 & 0 & 100 & 2,39 & 8,8 & 2,3 & 13,9 & 7,0 & 2,1 & 1,4 \\
4 & 0 & 150 & 2,56 & 8,8 & 2,5 & 13,6 & 7,3 & 2,2 & 1,4 \\
5 & 100 & 0 & 2,57 & 17,6 & 1,9 & 14,1 & 6,3 & 3,2 & 2,1 \\
6 & 100 & 50 & 3,05 & 17,6 & 2,0 & 14,1 & 6,4 & 3,1 & 2,1 \\
7 & 100 & 100 & 3,82 & 17,6 & 2,2 & 14,1 & 6,6 & 3,1 & 2,1 \\
8 & 100 & 150 & 4,90 & 17,6 & 2,4 & 14,1 & 6,7 & 3,1 & 2,1 \\
9 & 200 & 0 & 3,10 & 26,4 & 1,8 & 14,4 & 5,6 & 4,3 & 2,8 \\
10 & 200 & 50 & 3,59 & 26,4 & 1,9 & 14,0 & 5,8 & 3,9 & 2,8 \\
11 & 200 & 100 & 4,66 & 26,4 & 2,1 & 14,0 & 5,9 & 4,0 & 2,8 \\
12 & 200 & 150 & 6,31 & 26,4 & 2,2 & 14,0 & 6,1 & 4,0 & 2,8 \\
\hline
\end{tabular}

Fonte: Adaptado de Belarmino, 2001. 
Observa-se, na Tabela 31, que as concentrações dos minerais foram influenciadas pelas doses de $\mathrm{N}$ e $\mathrm{P}$, ocorrendo aumento das concentrações de $\mathrm{N}$ e $\mathrm{P}$ à medida que se aumentaram as doses desses minerais. Além disso, ocorreram aumentos nas concentrações de macronutrientes secundários, como o enxofre, devido à fonte de $\mathrm{N}$ e $\mathrm{P}$ utilizada. Também pode ser observada a resposta da planta às adubações a partir do aumento de produção de massa seca.

Utilizando os dados da Tabela 31, foram calculados os índices DRIS de cada nutriente e o Índice de Balanço Nutricional médio (IBNm), a partir dos métodos propostos por Beaufils (1973), Elwali \& Gascho (1984) e Jones (1981), expostos nas Tabelas 32, 33 e 34, respectivamente. Os dados de Belarmino (2001) não continham as concentrações dos micronutrientes. Assim, foram utilizadas as concentrações médias desses minerais determinadas na norma DRIS, para que tivessem pouca influência nos índices DRIS e IBNm. 
Tabela 32. Índices DRIS calculados a partir do método proposto por Beaufils (1973), em função das doses de nitrogênio e fósforo em capim Tanzânia e ordem de limitação entre os macronutrientes

\begin{tabular}{|c|c|c|c|c|c|c|c|c|c|c|c|c|c|}
\hline \multirow{2}{*}{$N^{0}$} & \multicolumn{11}{|c|}{ Índice DRIS } & \multirow{2}{*}{ IBNm } & \multirow{2}{*}{$\begin{array}{c}\text { Ordem de } \\
\text { limitação }\end{array}$} \\
\hline & $\mathrm{N}$ & $\mathrm{P}$ & $\mathrm{K}$ & $\mathrm{Ca}$ & $\mathrm{Mg}$ & $S$ & $\mathrm{Fe}$ & $\mathrm{Mn}$ & $\mathrm{Zn}$ & $\mathrm{Cu}$ & B & & \\
\hline 1 & $-21,6$ & $-1,4$ & $-15,5$ & 11,3 & $-6,3$ & 10,1 & 1,1 & 2,5 & 8,2 & 5,0 & 6,6 & 8,1 & $\mathrm{~N}>\mathrm{K}>\mathrm{Mg}$ \\
\hline 2 & $-22,5$ & 0,8 & $-16,6$ & 12,0 & $-4,8$ & 9,5 & 0,9 & 2,2 & 7,6 & 4,6 & 6,0 & 8,0 & $\mathrm{~N}>\mathrm{K}>\mathrm{Mg}$ \\
\hline 3 & $-23,0$ & 3,1 & $-17,7$ & 13,3 & $-6,3$ & 9,6 & 0,9 & 2,2 & 7,6 & 4,6 & 5,9 & 8,6 & $\mathrm{~N}>\mathrm{K}>\mathrm{Mg}$ \\
\hline 4 & $-23,7$ & 5,1 & $-19,4$ & 14,4 & $-6,0$ & 9,4 & 0,8 & 2,0 & 7,4 & 4,4 & 5,6 & 8,9 & $\mathrm{~N}>\mathrm{K}>\mathrm{Mg}$ \\
\hline 5 & $-3,0$ & $-5,2$ & $-22,3$ & 6,0 & 1,1 & 16,4 & $-0,8$ & $-0,1$ & 2,7 & 2,1 & 3,0 & 5,7 & $K>P>N$ \\
\hline 6 & $-3,2$ & $-3,3$ & $-22,5$ & 6,4 & 0,1 & 16,2 & $-0,9$ & $-0,2$ & 2,5 & 2,0 & 2,8 & 5,5 & $\mathrm{~K}>\mathrm{P}>\mathrm{N}$ \\
\hline 7 & $-3,4$ & $-1,7$ & $-22,8$ & 6,7 & $-0,3$ & 16,0 & $-1,0$ & $-0,3$ & 2,3 & 1,9 & 2,6 & 5,4 & $K>N>P$ \\
\hline 8 & $-3,7$ & $-0,3$ & $-23,2$ & 7,0 & $-0,1$ & 15,7 & $-1,1$ & $-0,4$ & 2,1 & 1,7 & 2,3 & 5,2 & $\mathrm{~K}>\mathrm{N}>\mathrm{P}$ \\
\hline 9 & 5,7 & $-9,9$ & $-26,6$ & 1,2 & 6,9 & 24,6 & $-1,9$ & $-1,5$ & $-0,4$ & 0,6 & 1,3 & 7,3 & $\mathrm{~K}>\mathrm{P}>\mathrm{Ca}$ \\
\hline 10 & 5,7 & $-7,3$ & $-27,9$ & 1,9 & 4,4 & 24,8 & $-1,9$ & $-1,5$ & $-0,3$ & 0,7 & 1,3 & 7,0 & $\mathrm{~K}>\mathrm{P}>\mathrm{Ca}$ \\
\hline 11 & 5,4 & $-5,4$ & $-28,3$ & 2,2 & 4,5 & 24,3 & $-2,0$ & $-1,6$ & $-0,6$ & 0,5 & 1,0 & 6,9 & $\mathrm{~K}>\mathrm{P}>\mathrm{Ca}$ \\
\hline 12 & 5,1 & $-3,7$ & $-28,7$ & 2,6 & 4,6 & 23,9 & $-2,1$ & $-1,8$ & $-0,8$ & 0,3 & 0,7 & 6,7 & $\mathrm{~K}>\mathrm{P}>\mathrm{Ca}$ \\
\hline
\end{tabular}


Tabela 33. Índices DRIS calculados a partir do método proposto por Elwali \& Gascho (1984), em função das doses de nitrogênio e fósforo em capim Tanzânia e ordem de limitação entre os macronutrientes

\begin{tabular}{|c|c|c|c|c|c|c|c|c|c|c|c|c|c|}
\hline \multirow{2}{*}{$N^{0}$} & \multicolumn{11}{|c|}{ Índice DRIS } & \multirow{2}{*}{ IBNm } & \multirow{2}{*}{$\begin{array}{l}\text { Ordem de } \\
\text { limitação }\end{array}$} \\
\hline & $\mathrm{N}$ & $P$ & $\mathrm{~K}$ & $\mathrm{Ca}$ & $\mathrm{Mg}$ & $S$ & $\mathrm{Fe}$ & $\mathrm{Mn}$ & $\mathrm{Zn}$ & $\mathrm{Cu}$ & B & & \\
\hline 1 & $-21,2$ & 0,0 & $-15,1$ & 9,8 & $-4,9$ & 9,3 & 1,1 & 2,8 & 8,0 & 4,2 & 6,0 & 7,5 & $\mathrm{~N}>\mathrm{K}>\mathrm{Mg}$ \\
\hline 2 & $-22,1$ & 2,3 & $-16,1$ & 10,1 & $-2,8$ & 9,1 & 1,1 & 2,8 & 7,2 & 3,3 & 5,0 & 7,4 & $\mathrm{~N}>\mathrm{K}>\mathrm{Mg}$ \\
\hline 3 & $-22,7$ & 4,0 & $-17,2$ & 11,4 & $-5,3$ & 9,4 & 1,1 & 2,9 & 6,9 & 4,2 & 5,3 & 8,2 & $\mathrm{~N}>\mathrm{K}>\mathrm{Mg}$ \\
\hline 4 & $-23,4$ & 5,1 & $-18,7$ & 13,3 & $-5,0$ & 9,4 & 1,1 & 2,4 & 6,8 & 4,2 & 4,7 & 8,6 & $\mathrm{~N}>\mathrm{K}>\mathrm{Mg}$ \\
\hline 5 & $-1,8$ & $-3,5$ & $-21,4$ & 5,0 & 1,0 & 15,9 & $-0,6$ & 0,5 & 1,9 & 1,0 & 2,0 & 5,0 & $\mathrm{~K}>\mathrm{P}>\mathrm{N}$ \\
\hline 6 & $-1,9$ & $-1,4$ & $-21,6$ & 5,0 & 0,7 & 15,7 & $-0,6$ & 0,5 & 1,2 & 1,0 & 1,3 & 4,6 & $\mathrm{~K}>\mathrm{N}>\mathrm{P}$ \\
\hline 7 & $-2,0$ & $-0,8$ & $-21,9$ & 5,6 & 0,1 & 15,5 & $-0,6$ & 0,5 & 1,2 & 1,0 & 1,3 & 4,6 & $K>N>P$ \\
\hline 8 & $-2,1$ & $-0,2$ & $-22,4$ & 5,7 & 0,2 & 15,3 & $-0,6$ & 0,5 & 1,2 & 1,0 & 1,3 & 4,6 & $\mathrm{~K}>\mathrm{N}>\mathrm{P}$ \\
\hline 9 & 3,7 & $-8,6$ & $-25,8$ & 1,8 & 5,4 & 24,6 & $-1,1$ & $-0,3$ & $-0,9$ & 0,3 & 0,9 & 6,7 & $\mathrm{~K}>\mathrm{P}>\mathrm{Ca}$ \\
\hline 10 & 3,5 & $-5,7$ & $-27,0$ & 1,9 & 3,1 & 24,8 & $-1,1$ & $-0,2$ & $-1,0$ & 0,4 & 1,3 & 6,4 & $\mathrm{~K}>\mathrm{P}>\mathrm{Ca}$ \\
\hline 11 & 3,3 & $-3,8$ & $-27,4$ & 2,0 & 3,0 & 24,3 & $-1,1$ & $-0,2$ & $-1,0$ & 0,4 & 0,6 & 6,1 & $\mathrm{~K}>\mathrm{P}>\mathrm{Ca}$ \\
\hline 12 & 3,1 & $-2,8$ & $-27,9$ & 2,0 & 3,0 & 23,9 & $-1,1$ & $-0,2$ & $-1,0$ & 0,4 & 0,6 & 6,0 & $\mathrm{~K}>\mathrm{P}>\mathrm{Ca}$ \\
\hline
\end{tabular}


Tabela 34. Índices DRIS calculados a partir do método proposto por Jones (1981), em função das doses de nitrogênio e fósforo em capim Tanzânia e ordem de limitação entre os macronutrientes

\begin{tabular}{|c|c|c|c|c|c|c|c|c|c|c|c|c|c|}
\hline \multirow{2}{*}{$\mathrm{N}^{0}$} & \multicolumn{11}{|c|}{ Índice DRIS } & \multirow{2}{*}{ IBNm } & \multirow{2}{*}{$\begin{array}{l}\text { Ordem de } \\
\text { limitação }\end{array}$} \\
\hline & $\mathrm{N}$ & $P$ & $\mathrm{~K}$ & $\mathrm{Ca}$ & $\mathrm{Mg}$ & $S$ & $\mathrm{Fe}$ & $\mathrm{Mn}$ & $\mathrm{Zn}$ & $\mathrm{Cu}$ & $B$ & & \\
\hline 1 & $-9,5$ & $-0,9$ & $-7,9$ & 6,4 & $-4,4$ & 4,8 & 0,2 & 1,0 & 4,2 & 2,6 & 3,6 & 4,1 & $\mathrm{~N}>\mathrm{K}>\mathrm{Mg}$ \\
\hline 2 & $-9,7$ & 0,4 & $-8,5$ & 6,8 & $-3,7$ & 4,5 & 0,0 & 0,8 & 3,8 & 2,4 & 3,2 & 4,0 & $\mathrm{~N}>\mathrm{K}>\mathrm{Mg}$ \\
\hline 3 & $-9,8$ & 2,1 & $-9,0$ & 7,6 & $-4,8$ & 4,4 & 0,0 & 0,7 & 3,6 & 2,3 & 3,0 & 4,3 & $\mathrm{~N}>\mathrm{K}>\mathrm{Mg}$ \\
\hline 4 & $-9,8$ & 3,6 & $-9,8$ & 8,1 & $-4,8$ & 4,2 & $-0,1$ & 0,5 & 3,3 & 2,1 & 2,7 & 4,5 & $\mathrm{~N}>\mathrm{K}>\mathrm{Mg}$ \\
\hline 5 & $-1,5$ & $-3,1$ & $-11,0$ & 3,6 & 0,3 & 9,8 & $-1,0$ & $-0,6$ & 0,9 & 1,0 & 1,6 & 3,1 & $\mathrm{~K}>\mathrm{P}>\mathrm{N}$ \\
\hline 6 & $-1,7$ & $-1,9$ & $-11,2$ & 3,9 & $-0,4$ & 9,8 & $-1,0$ & $-0,7$ & 0,8 & 0,9 & 1,5 & 3,1 & $\mathrm{~K}>\mathrm{P}>\mathrm{N}$ \\
\hline 7 & $-1,8$ & $-0,7$ & $-11,5$ & 4,2 & $-0,7$ & 9,7 & $-1,1$ & $-0,8$ & 0,6 & 0,8 & 1,3 & 3,0 & $K>N>P$ \\
\hline 8 & $-2,0$ & 0,3 & $-11,8$ & 4,4 & $-0,6$ & 9,6 & $-1,2$ & $-0,9$ & 0,4 & 0,7 & 1,1 & 3,0 & $\mathrm{~K}>\mathrm{N}>\mathrm{Mg}$ \\
\hline 9 & 6,3 & $-5,7$ & $-12,7$ & 0,5 & 4,0 & 14,5 & $-2,1$ & $-2,1$ & $-2,1$ & $-0,5$ & $-0,1$ & 4,6 & $\mathrm{~K}>\mathrm{P}>\mathrm{Ca}$ \\
\hline 10 & 6,3 & $-4,3$ & $-13,4$ & 0,9 & 2,5 & 14,6 & $-2,0$ & $-2,0$ & $-2,1$ & $-0,4$ & $-0,1$ & 4,4 & $\mathrm{~K}>\mathrm{P}>\mathrm{Ca}$ \\
\hline 11 & 6,0 & $-3,1$ & $-13,6$ & 1,1 & 2,6 & 14,5 & $-2,1$ & $-2,2$ & $-2,3$ & $-0,6$ & $-0,3$ & 4,4 & $\mathrm{~K}>\mathrm{P}>\mathrm{Ca}$ \\
\hline 12 & 5,7 & $-2,0$ & $-13,9$ & 1,4 & 2,7 & 14,4 & $-2,2$ & $-2,3$ & $-2,5$ & $-0,7$ & $-0,5$ & 4,4 & $\mathrm{~K}>\mathrm{P}>\mathrm{Ca}$ \\
\hline
\end{tabular}

Comparando os resultados nas Tabelas 32, 33 e 34, observa-se que existe uma semelhança entre os valores de índice DRIS gerados pelos três métodos propostos, mas os resultados mostram a ocorrência de índices mais negativos quando calculados pelos métodos de Beaufils (1973) e Elwali \& Gascho (1984) em comparação aos obtidos pelo método Jones (1981).

Com relação à ordem de limitação nutricional entre os macronutrientes, observa-se similaridade entre os métodos utilizados para cálculo do índice DRIS, indicando, na maioria das vezes, os mesmos nutrientes limitantes. As Tabelas 32, 33 e 34 demonstram que existe uma concordância entre os tratamentos (doses de N e P) e os índices DRIS obtidos. Observa-se que, com 
o aumento da dose de nitrogênio, ocorre neutralização do índice $\mathrm{N}$ e posterior acréscimo devido a um acúmulo de nitrogênio, como pode ser observado na Tabela 31. Do mesmo modo, com relação ao fósforo, o índice $P$ acompanha as doses de P. As Tabelas 32, 33 e 34 demonstram que, à medida que aumentam as doses de N, o índice $P$ tende a ser negativo, indicando uma relação entre doses de $\mathrm{N}$ e necessidade de $\mathrm{P}$. No mesmo sentido, ao analisar os índices $\mathrm{K}$, observa-se que este fica mais negativo à medida que aumenta a dose de $\mathrm{N}$, demonstrando mais uma vez a interatividade entre os nutrientes, que, por meio do método DRIS, pode ser mais facilmente analisada.

Com o objetivo de comparar a diagnose foliar a partir do método da faixa de suficiência e do DRIS, classificou-se as concentrações encontradas por Belarmino (2001) em cada tratamento em deficiente, equilibrada e excessiva, utilizando as faixas de suficiência propostas por Werner et al. (1997) (Tabela 35). Do mesmo modo, classificou-se os índices DRIS de cada nutriente como deficiente, equilibrado e excessivo (Tabela 36). Com os dados da Tabela 35 e 36 , determinou-se a porcentagem de concordância entre a diagnose obtida pelo DRIS e pela faixa de suficiência adotada como padrão (Tabela 37) para classificar as amostras como deficientes, adequadas ou excessivas.

Tabela 35. Padrões nutricionais adotados para classificação dos nutrientes, adaptados das faixas de suficiência para parte aérea do capim colonião, propostas por Werner et al. (1997)

\begin{tabular}{cccccccc}
\hline & \multicolumn{7}{c}{ Padrão nutricional (Werner et al. 1997) } \\
\hline Classificação & $\mathrm{N}$ & $\mathrm{P}$ & $\mathrm{K}$ & $\mathrm{Ca}$ & $\mathrm{Mg}$ & $\mathrm{S}$ \\
& & \multicolumn{7}{c}{$\mathrm{g} / \mathrm{kg} \mathrm{MS}$} \\
Deficiente & $<15$ & $<1$ & $<15$ & $<3$ & $<1,5$ & $<1$ \\
Equilibrada & 15 a 25 & 1 a 3 & 15 a 30 & 3 a 8 & 1,5 a 5,0 & 1 a 3 \\
Excessiva & $>25$ & $>3$ & $>30$ & $>8$ & $>5$ & $>3$ \\
\hline
\end{tabular}


Tabela 36. Padrão de classificação dos índices DRIS

\begin{tabular}{cl}
\hline Classificação & \multicolumn{1}{c}{ Descrição } \\
\cline { 2 - 2 } Deficiente & Índice DRIS negativo e maior em valor absoluto que o IBNm \\
Equilibrada & Índice DRIS em valor absoluto, menor que o IBNm \\
Excessiva & Índice DRIS positivo e maior que o IBNm \\
\hline
\end{tabular}

Tabela 37. Porcentagem de concordância entre os índices DRIS e os padrões adotados por Werner et al. (1997)

\begin{tabular}{ccccccc}
\hline & \multicolumn{7}{c}{ Concordância (\%) } \\
\hline Método & $\mathrm{N}$ & $\mathrm{P}$ & $\mathrm{K}$ & $\mathrm{Ca}$ & $\mathrm{Mg}$ & $\mathrm{S}$ \\
Beaufils & 100 & 83 & 100 & 33 & 100 & 0 \\
Elwali \& Gascho & 100 & 91 & 100 & 33 & 66 & 8 \\
Jones & 66 & 91 & 100 & 33 & 100 & 0 \\
\hline
\end{tabular}

Pode-se observar alta concordância entre a diagnose estabelecida por meio dos índices DRIS e dos padrões estabelecidos (faixa de suficiência), exceção feita ao cálcio e ao enxofre (Tabela 37). Esses dois nutrientes apresentaram-se equilibrados em todos os tratamentos quando classificados a partir da faixa de suficiência proposta por Werner et al. (1997). Por outro lado, pela classificação por meio do IBNm, os nutrientes apresentaram variação entre equilibrada e excessiva, demonstrando que a classificação com base no índice DRIS do nutriente foi mais rigorosa que a faixa de suficiência. Ou seja, a faixa de suficiência proposta por Werner et al. (1997) é mais ampla em relação à faixa determinada pelo IBNm.

Com relação à comparação entre os métodos para determinar o índice DRIS, observa-se pouca variação. A Figura 7 demonstra o coeficiente de determinação das relações entre as concentrações de nitrogênio e fósforo e o índice DRIS desses nutrientes, calculados a partir dos métodos propostos por Beaufils (1973), Elwali \& Gascho (1984) e Jones (1981), em função das 
adubações de $\mathrm{N}$ e P. A Tabela 38 demonstra os coeficientes de determinação para todos os nutrientes estudados. Observa-se correlação positiva e significativa entre as concentrações dos nutrientes e seus respectivos índices DRIS. Essa correlação aumenta a segurança da utilização das normas DRIS desenvolvidas neste trabalho.

Neste sentido, trabalhos realizados por Rossi (1999), Colozza (1998) e Pereira (2001) demonstraram existir correlação entre a concentração do nutriente na planta e a produção de massa da forragem. Assim, deve ser esperada a correlação entre índices DRIS e a produção de massa seca. A exceção ocorreu para o índice de $\mathrm{K}$, pois não se relacionou com sua concentração. Ao analisar a Tabela 31, observa-se que as concentrações de $\mathrm{K}$ não variaram com os tratamentos e, ao mesmo tempo, apresentaram valores abaixo dos níveis críticos para esse nutriente. Por outro lado, nas Tabelas 32, 33 e 34, o índice de K variou em função dos tratamentos, sendo mais negativo à medida que aumentou a adubação nitrogenada. Assim, a relação entre concentração e índice de K não era esperada.

Tabela 38. Coeficiente de determinação entre os índices DRIS, gerados a partir das funções calculadas pelos métodos propostos por Beaufils (1973), Jones (1981) e Elwali \& Gascho (1984), e as concentrações dos macronutrientes, do experimento realizado por Belarmino (2001)

\begin{tabular}{ccccccc}
\hline Método & $\mathrm{N}$ & $\mathrm{P}$ & $\mathrm{K}$ & $\mathrm{Ca}$ & $\mathrm{Mg}$ & $\mathrm{S}$ \\
\hline Beaufils & $0,96^{\star}$ & $0,62^{\star *}$ & 0,00 & $0,70^{\star}$ & $0,99^{\star}$ & $0,99^{\star}$ \\
$\begin{array}{c}\text { Elwali \& } \\
\text { Gascho }\end{array}$ & $0,95^{\star}$ & $0,54^{\star \star \star}$ & 0,00 & $0,67^{\star}$ & $0,91^{\star}$ & $0,98^{\star}$ \\
Jones & $0,99^{\star}$ & $0,72^{\star}$ & 0,00 & $0,73^{\star}$ & $0,98^{\star}$ & $0,99^{\star}$ \\
\hline
\end{tabular}

* Significância a 1\% de probabilidade, ** Significância a 5\% de probabilidade e

*** Significância a 10\% de probabilidade 

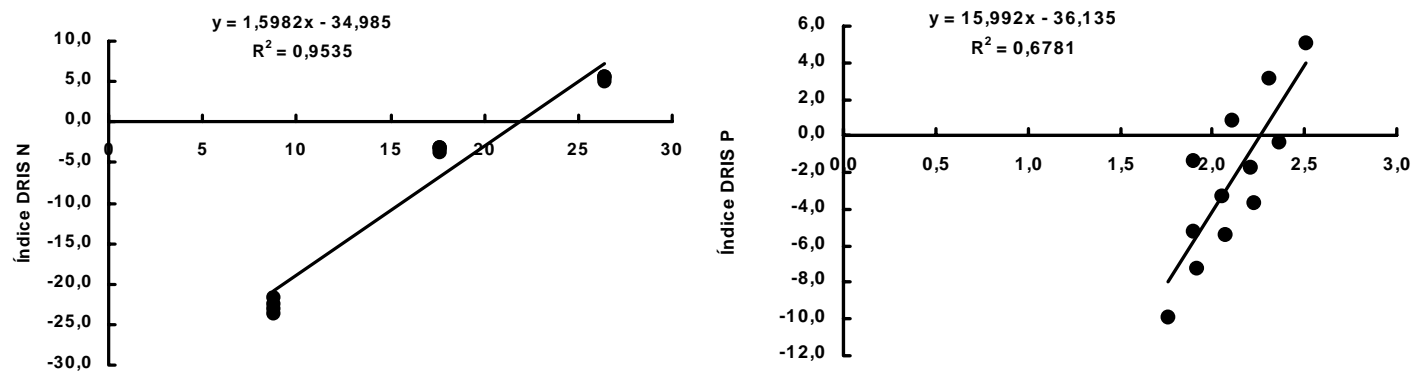

Nitrogênio $\left(\mathrm{g} \mathrm{kg}^{-1}\right)$ Beaufils (1973)

Fósforo $\left(\mathrm{g} \mathrm{kg}^{-1}\right)$ Beaufils (1973)
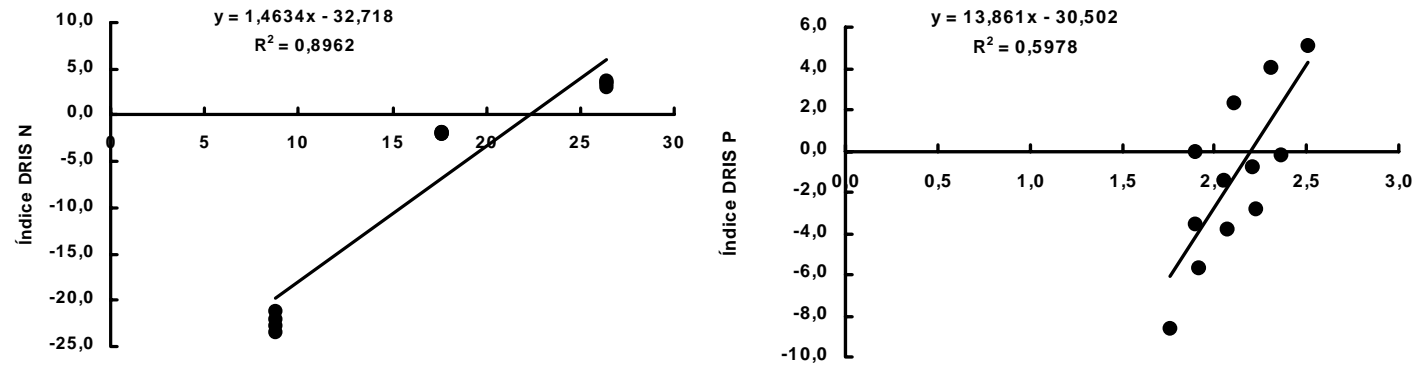

Nitrogênio $\left(\mathrm{g} \mathrm{kg}^{-1}\right)$ Elwali \& Gascho (1984)

Fósforo $\left(\mathrm{g} \mathrm{kg}^{-1}\right)$ Elwali \& Gascho (1984)
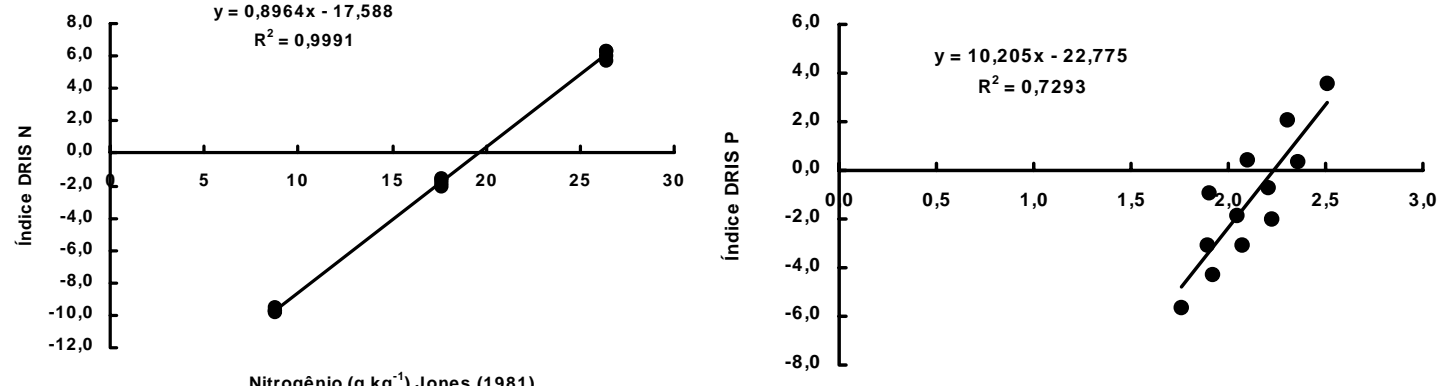

Fósforo $\left(\mathrm{g} \mathrm{kg}^{-1}\right)$ Jones (1981)

Figura 7 - Regressões ajustadas entre índices DRIS de $\mathrm{N}$ e $\mathrm{P}$, calculados a partir dos métodos propostos por Beaufils (1973), Elwali \& Gascho (1984) e Jones (1981), e concentrações de N e P (g/kg MS)

A Figura 8 demonstra a relação entre a produção e o IBN (índice de Balanço Nutricional) nos métodos propostos por Beaufils (1973), Elwali \& Gascho (1984). Observa-se que os valores de coeficiente de determinação são baixos $(0,21$ e 0,22), mas significativos, demonstrando uma relação linear inversa entre IBN e produção de massa seca. 
O IBN nem sempre acompanha os valores de produtividade, pois, à medida que o índice DRIS de determinado nutriente melhora, possivelmente, outro índice tende a apresentar variação. Pode-se observar, nas Tabelas 32, 33 e 34, que, à medida que o índice de $\mathrm{N}$ melhorou, os índices de potássio e enxofre pioraram. Desse modo, como o IBN é a somatória dos índices, este não diminuiu, embora a produção continuasse aumentando, pois a forrageira não foi sensível a esse excesso de determinados nutrientes.

Creste \& Nakagawa (1997), em estudo para estabelecer as normas DRIS para limoeiro, obtiveram o coeficiente de determinação 0,57 , em uma relação linear negativa entre o IBN e a produção de limão. Neste sentido, segundo Beaufils (1973), o IBN deve ser inversamente relacionado à produção, isto é, quanto maior o valor do IBN, maior a intensidade de desequilíbrio nutricional.

Silva et al. (2000) avaliaram o estado nutricional do cafeeiro em resposta à adubação potássica utilizando o DRIS. Nesse estudo, os autores determinaram uma correlação linear negativa entre o IBN e a produção, sendo 0,72 o coeficiente de determinação obtido. Do mesmo modo, Veloso et al. (2000) determinaram as normas DRIS para cultura de citros na região nordeste do Estado do Pará, obtendo correlação linear entre IBN e produção, por meio de um coeficiente de determinação igual a 0,61. Por outro lado, Silveira et al. (2003), trabalhando com Brachiaria decumbens, não conseguiram estabelecer relação entre o IBN e a produção da forrageira.

Pode-se concluir que, possivelmente, as normas DRIS geradas até o presente momento para gramíneas tropicais sejam mais rígidas com relação ao balanço nutricional do que a resposta da planta em produção com relação a esse balanço. Dessa maneira, mais estudos sobre o DRIS em forrageiras tropicais devem ser realizados, possibilitando maiores conclusões. 

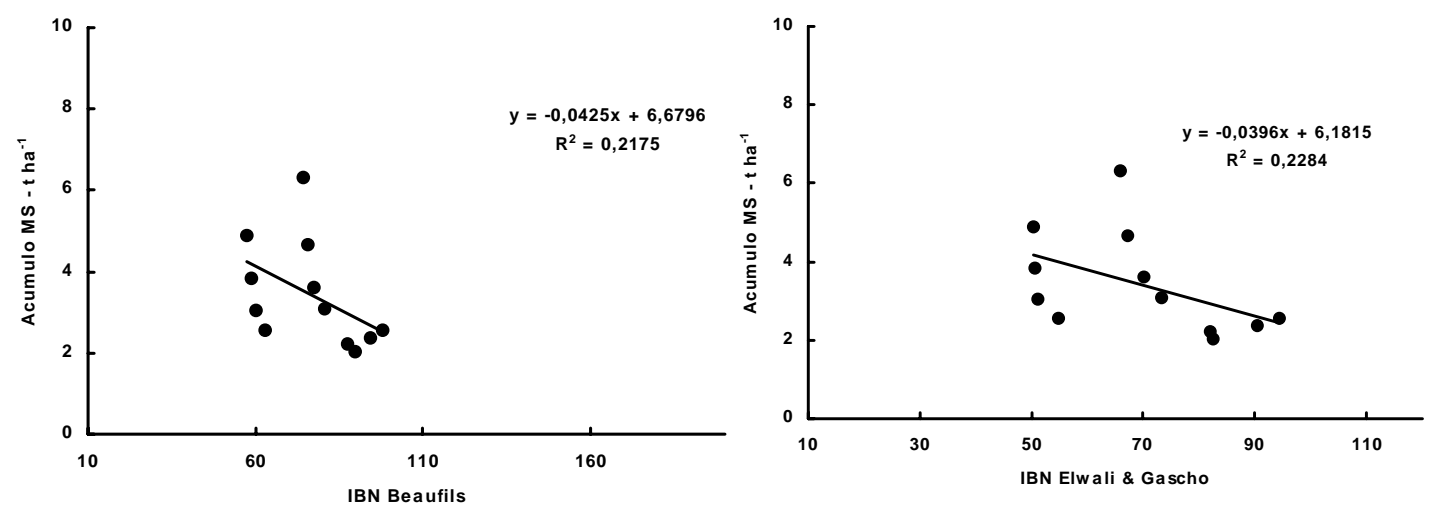

Figura 8 - Regressões ajustadas entre os Índices de Balanço Nutricional (IBN) calculados a partir dos métodos propostos por Beaufils (1973)* e Elwali \& Gascho (1984)*, e produção de massa seca (t MS/ha)

* Significância a 10\% de probabilidade.

Com relação aos métodos utilizados para cálculo das funções e posterior determinação do índice DRIS para cada nutriente, apenas os métodos propostos por Beaufils (1973) e Elwali \& Gascho (1984) apresentaram coeficiente de determinação entre IBN e produção e significância estatística, demonstrando, dessa forma, superioridade dos métodos propostos por esses autores.

Utilizando o mesmo grupo de amostras que deram origem às normas DRIS a partir das concentrações de LFRE, foi realizada a elaboração de uma nova norma DRIS, mas, dessa vez, tendo como referência a concentração dos minerais na PT. As Tabelas 39 e 40 apresentam as normas DRIS para Panicum maximum cv. Tanzânia, com base na média, no coeficiente de variação (C.V.) e no desvio-padrão das relações diretas e inversas das concentrações dos nutrientes estudados na PT. 
Tabela 39. Normas DRIS (média, coeficiente de variação e desvio-padrão) para capim Tanzânia para os pares dos macro e micronutrientes na PT

\begin{tabular}{|c|c|c|c|c|c|c|c|}
\hline Relações & Média & C. V \%* & $S$ ** & Relações & Média & C. V \% * & $S^{* *}$ \\
\hline $\mathrm{N} / \mathrm{P}$ & 7,20 & 28,1 & 2,024 & $\mathrm{Ca} / \mathrm{N}$ & 0,27 & 33,0 & 0,090 \\
\hline $\mathrm{N} / \mathrm{K}$ & 0,73 & 29,2 & 0,212 & $\mathrm{Ca} / \mathrm{P}$ & 2,26 & 47,5 & 1,073 \\
\hline $\mathrm{N} / \mathrm{Ca}$ & 3,97 & 30,6 & 1,215 & $\mathrm{Ca} / \mathrm{K}$ & 0,20 & 61,3 & 0,121 \\
\hline $\mathrm{N} / \mathrm{Mg}$ & 6,17 & 17,6 & 1,087 & $\mathrm{Ca} / \mathrm{Mg}$ & 1,65 & 27,4 & 0,452 \\
\hline$N / S$ & 14,71 & 14,5 & 2,138 & $\mathrm{Ca} / \mathrm{S}$ & 3,95 & 27,9 & 1,101 \\
\hline $\mathrm{N} / \mathrm{Fe}$ & 0,10 & 59,8 & 0,059 & $\mathrm{Ca} / \mathrm{Fe}$ & 0,03 & 50,1 & 0,014 \\
\hline $\mathrm{N} / \mathrm{Mn}$ & 0,19 & 35,0 & 0,066 & $\mathrm{Ca} / \mathrm{Mn}$ & 0,05 & 27,4 & 0,014 \\
\hline$N / Z n$ & 0,81 & 14,1 & 0,114 & $\mathrm{Ca} / \mathrm{Zn}$ & 0,22 & 9,7 & 0,021 \\
\hline $\mathrm{N} / \mathrm{Cu}$ & 2,07 & 29,2 & 0,605 & $\mathrm{Ca} / \mathrm{Cu}$ & 0,57 & 47,8 & 0,274 \\
\hline N/B & 2,40 & 19,4 & 0,465 & $\mathrm{Ca} / \mathrm{B}$ & 0,64 & 29,2 & 0,188 \\
\hline $\mathrm{P} / \mathrm{N}$ & 0,13 & 32,1 & 0,041 & $\mathrm{Mg} / \mathrm{N}$ & 0,17 & 29,2 & 0,050 \\
\hline $\mathrm{P} / \mathrm{K}$ & 0,09 & 23,2 & 0,021 & $\mathrm{Mg} / \mathrm{P}$ & 1,45 & 36,8 & 0,533 \\
\hline $\mathrm{P} / \mathrm{Ca}$ & 0,49 & 49,4 & 0,242 & $\mathrm{Mg} / \mathrm{K}$ & 0,12 & 42,7 & 0,052 \\
\hline $\mathrm{P} / \mathrm{Mg}$ & 0,77 & 25,9 & 0,199 & $\mathrm{Mg} / \mathrm{Ca}$ & 0,68 & 44,1 & 0,298 \\
\hline P/S & 1,86 & 36,9 & 0,686 & $\mathrm{Mg} / \mathrm{S}$ & 2,53 & 30,6 & 0,774 \\
\hline $\mathrm{P} / \mathrm{Fe}$ & 0,01 & 93,6 & 0,012 & $\mathrm{Mg} / \mathrm{Fe}$ & 0,02 & 85,8 & 0,014 \\
\hline $\mathrm{P} / \mathrm{Mn}$ & 0,02 & 47,4 & 0,011 & $\mathrm{Mg} / \mathrm{Mn}$ & 0,03 & 60,1 & 0,020 \\
\hline $\mathrm{P} / \mathrm{Zn}$ & 0,10 & 20,9 & 0,021 & $\mathrm{Mg} / \mathrm{Zn}$ & 0,14 & 25,2 & 0,034 \\
\hline $\mathrm{P} / \mathrm{Cu}$ & 0,25 & 28,6 & 0,071 & $\mathrm{Mg} / \mathrm{Cu}$ & 0,33 & 38,4 & 0,128 \\
\hline P/B & 0,30 & 22,1 & 0,065 & $\mathrm{Mg} / \mathrm{B}$ & 0,40 & 25,9 & 0,103 \\
\hline $\mathrm{K} / \mathrm{N}$ & 1,46 & 43,2 & 0,632 & $\mathrm{~S} / \mathrm{N}$ & 0,07 & 18,7 & 0,013 \\
\hline $\mathrm{K} / \mathrm{P}$ & 12,27 & 33,9 & 4,162 & $\mathrm{~S} / \mathrm{P}$ & 0,60 & 28,1 & 0,168 \\
\hline $\mathrm{K} / \mathrm{Ca}$ & 5,80 & 66,9 & 3,877 & $S / K$ & 0,05 & 36,0 & 0,018 \\
\hline $\mathrm{K} / \mathrm{Mg}$ & 8,72 & 31,8 & 2,771 & $\mathrm{~S} / \mathrm{Ca}$ & 0,28 & 33,8 & 0,093 \\
\hline $\mathrm{K} / \mathrm{S}$ & 21,31 & 45,8 & 9,764 & $\mathrm{~S} / \mathrm{Mg}$ & 0,44 & 22,4 & 0,098 \\
\hline $\mathrm{K} / \mathrm{Fe}$ & 0,14 & 122,4 & 0,169 & $\mathrm{~S} / \mathrm{Fe}$ & 0,01 & 61,0 & 0,004 \\
\hline $\mathrm{K} / \mathrm{Mn}$ & 0,27 & 69,3 & 0,187 & $\mathrm{~S} / \mathrm{Mn}$ & 0,01 & 35,5 & 0,005 \\
\hline $\mathrm{K} / \mathrm{Zn}$ & 1,14 & 34,0 & 0,388 & $S / Z n$ & 0,06 & 15,1 & 0,009 \\
\hline $\mathrm{K} / \mathrm{Cu}$ & 2,90 & 33,9 & 0,983 & $\mathrm{~S} / \mathrm{Cu}$ & 0,15 & 31,2 & 0,047 \\
\hline $\mathrm{K} / \mathrm{B}$ & 3,40 & 34,5 & 1,176 & S/B & 0,17 & 22,7 & 0,039 \\
\hline
\end{tabular}


Tabela 40. Normas DRIS (média, coeficiente de variação e desvio-padrão) para capim Tanzânia para os pares dos macro e micronutrientes na PT

\begin{tabular}{|c|c|c|c|c|c|c|c|}
\hline Relações & Média & C. V\% * & $S^{* *}$ & Relações & Média & C. V\%* & $\mathbf{S}^{* *}$ \\
\hline $\mathrm{Fe} / \mathrm{N}$ & 13,46 & 113,1 & 15,230 & $\mathrm{Zn} / \mathrm{S}$ & 18,84 & 63,7 & 12,008 \\
\hline $\mathrm{Fe} / \mathrm{P}$ & 118,34 & 117,7 & 139,346 & $\mathrm{Zn} / \mathrm{Fe}$ & 0,12 & 126,8 & 0,158 \\
\hline $\mathrm{Fe} / \mathrm{K}$ & 9,05 & 150,9 & 13,654 & $\mathrm{Zn} / \mathrm{Mn}$ & 0,24 & 59,4 & 0,142 \\
\hline $\mathrm{Fe} / \mathrm{Ca}$ & 53,73 & 77,9 & 41,844 & $\mathrm{Zn} / \mathrm{Cu}$ & 2,52 & 105,6 & 2,664 \\
\hline $\mathrm{Fe} / \mathrm{Mg}$ & 77,81 & 99,2 & 77,174 & $\mathrm{Zn} / \mathrm{B}$ & 3,00 & 72,9 & 2,183 \\
\hline $\mathrm{Fe} / \mathrm{S}$ & 188,06 & 94,6 & 177,824 & $\mathrm{Cu} / \mathrm{N}$ & 0,63 & 56,5 & 0,354 \\
\hline $\mathrm{Fe} / \mathrm{Mn}$ & 2,51 & 57,6 & 1,447 & $\mathrm{Cu} / \mathrm{P}$ & 5,13 & 53,8 & 2,763 \\
\hline $\mathrm{Fe} / \mathrm{Zn}$ & 10,24 & 41,6 & 4,264 & $\mathrm{Cu} / \mathrm{K}$ & 0,42 & 30,5 & 0,129 \\
\hline $\mathrm{Fe} / \mathrm{Cu}$ & 26,63 & 119,3 & 31,765 & $\mathrm{Cu} / \mathrm{Ca}$ & 2,53 & 79,1 & 2,000 \\
\hline $\mathrm{Fe} / \mathrm{B}$ & 31,85 & 95,3 & 30,356 & $\mathrm{Cu} / \mathrm{Mg}$ & 3,58 & 38,6 & 1,384 \\
\hline $\mathrm{Mn} / \mathrm{N}$ & 6,41 & 84,2 & 5,398 & $\mathrm{Cu} / \mathrm{S}$ & 9,26 & 48,9 & 4,524 \\
\hline $\mathrm{Mn} / \mathrm{P}$ & 51,52 & 71,4 & 36,808 & $\mathrm{Cu} / \mathrm{Fe}$ & 0,06 & 77,9 & 0,048 \\
\hline $\mathrm{Mn} / \mathrm{K}$ & 4,48 & 91,7 & 4,111 & $\mathrm{Cu} / \mathrm{Mn}$ & 0,12 & 64,5 & 0,076 \\
\hline $\mathrm{Mn} / \mathrm{Ca}$ & 25,11 & 89,3 & 22,431 & $\mathrm{Cu} / \mathrm{Zn}$ & 0,47 & 38,8 & 0,183 \\
\hline $\mathrm{Mn} / \mathrm{Mg}$ & 39,61 & 73,3 & 29,025 & $\mathrm{Cu} / \mathrm{B}$ & 1,35 & 51,8 & 0,700 \\
\hline $\mathrm{Mn} / \mathrm{S}$ & 93,94 & 74,0 & 69,489 & $\mathrm{~B} / \mathrm{N}$ & 0,48 & 41,9 & 0,202 \\
\hline $\mathrm{Mn} / \mathrm{Fe}$ & 0,65 & 129,7 & 0,844 & $\mathrm{~B} / \mathrm{P}$ & 3,99 & 32,6 & 1,303 \\
\hline $\mathrm{Mn} / \mathrm{Zn}$ & 5,03 & 31,7 & 1,595 & $\mathrm{~B} / \mathrm{K}$ & 0,34 & 50,7 & 0,173 \\
\hline $\mathrm{Mn} / \mathrm{Cu}$ & 13,37 & 79,2 & 10,582 & $\mathrm{~B} / \mathrm{Ca}$ & 1,86 & 54,7 & 1,020 \\
\hline $\mathrm{Mn} / \mathrm{B}$ & 15,34 & 61,0 & 9,352 & $\mathrm{~B} / \mathrm{Mg}$ & 2,86 & 27,4 & 0,783 \\
\hline $\mathrm{Zn} / \mathrm{N}$ & 1,30 & 72,6 & 0,945 & $\mathrm{~B} / \mathrm{S}$ & 7,26 & 50,5 & 3,666 \\
\hline $\mathrm{Zn} / \mathrm{P}$ & 10,81 & 88,3 & 9,547 & $\mathrm{~B} / \mathrm{Fe}$ & 0,05 & 102,4 & 0,051 \\
\hline $\mathrm{Zn} / \mathrm{K}$ & 0,91 & 129,5 & 1,179 & $\mathrm{~B} / \mathrm{Mn}$ & 0,09 & 66,0 & 0,060 \\
\hline $\mathrm{Zn} / \mathrm{Ca}$ & 5,07 & 49,8 & 2,527 & $\mathrm{~B} / \mathrm{Zn}$ & 0,38 & 24,6 & 0,093 \\
\hline $\mathrm{Zn} / \mathrm{Mg}$ & 7,73 & 75,6 & 5,844 & $\mathrm{~B} / \mathrm{Cu}$ & 0,90 & 43,0 & 0,388 \\
\hline
\end{tabular}



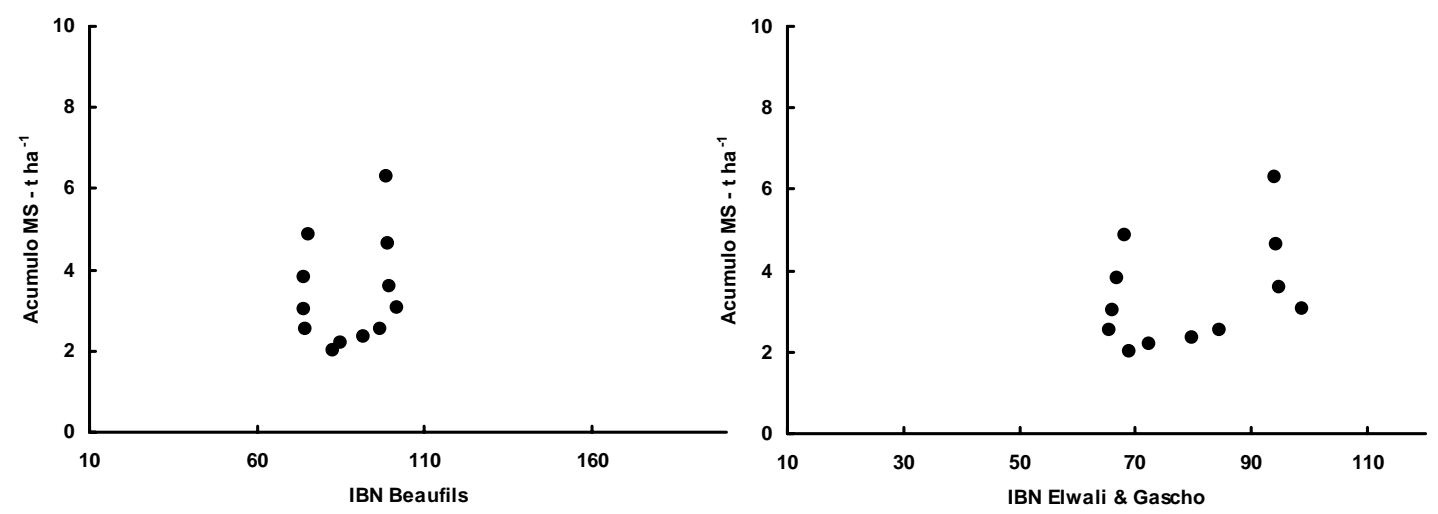

Figura 9 - Relação entre os Índices de Balanço Nutricional (IBN) calculados a partir dos métodos propostos por Beaufils (1973) e Elwali \& Gascho (1984), e produção de massa seca (t MS/ha), tendo a concentração dos minerais na PT como base para determinação das normas

A Figura 9 demonstra a relação entre o IBN e produção de massa seca. O IBN foi gerado utilizando as normas calculadas com base nas concentrações dos minerais na PT deste experimento, calculando, posteriormente, os índices DRIS de cada elemento nas doze amostras do experimento de Belarmino (2001) e, finalmente, seu IBN. Observa-se que a utilização das normas geradas a partir das concentrações dos minerais na PT para calcular o IBN não demonstra relação entre IBN e produção de massa seca. Deste modo, apesar dos baixos coeficientes de determinação observados na Figura 8, possivelmente, a utilização das LFRE é mais recomendada para o cálculo das normas DRIS. Neste sentido, faz-se necessário um maior número de estudos com gramíneas forrageiras para que se possa compreender melhor os resultados gerados pelo método DRIS. 


\section{CONCLUSÕES}

O período experimental apresentou significância estatística mais evidente nas concentrações dos minerais nas diferentes partes da planta forrageira em relação à intensidade de pastejo, ocorrendo maiores concentrações para a maioria dos minerais estudados no período 03 , referente ao inverno.

A intensidade de pastejo demonstrou pouca influência sobre a concentração dos minerais na planta, ocorrendo, na maioria das vezes, diferenças na concentração da LFM, como nos casos de N, P, S e Zn, sendo que estes apresentaram maiores concentrações na LFM no tratamento de alta intensidade de pastejo.

Em todos os períodos de coleta e intensidades de pastejo, a planta apresentou concentração na LFRE, de todos os nutrientes, acima dos níveis críticos internos propostos para Panicum maximum. A concentração de $\mathrm{Ca}$, no entanto, esteve mais próxima de apresentar-se deficiente, sendo esse comportamento justificado pela interação Ca e K.

Para os nutrientes estudados, com exceção ao $\mathrm{Fe}$, a concentração na LFRE não foi influenciada pelas intensidades de pastejo impostas pelos tratamentos. Assim, deve ser indicada para expressar o estado nutricional dessa forrageira.

Um maior consumo de minerais e uma maior quantidade de minerais retornando ao solo via excreta animal foram observados nos tratamentos de alta intensidade de pastejo. Do mesmo modo, uma maior porcentagem de minerais contidos na forragem pré-pastejo retornou ao solo via fezes e urina 
quando a pastagem foi manejada com alta intensidade de pastejo, variando de 30 a $49 \%$ para os macronutrientes.

O método DRIS para capim Tanzânia, com base nas normas determinadas a partir de uma população de alta produção, demonstrou-se eficiente para diagnosticar as amostras de tecido foliar como deficientes, equilibradas e excessivas. No entanto, existiu pouca relação entre IBN e produção de massa seca. Com relação aos métodos utilizados para cálculo das funções, o proposto por Jones (1981) demonstrou menores variações entre os índices DRIS e não apresentou relação do IBN com a produção de massa seca, o que determinou a indicação dos métodos propostos por Beaufils (1973) e Elwali \& Gascho (1984) para o cálculo do índice DRIS para capim Tanzânia. 


\section{REFERÊNCIAS BIBLIOGRÁFICAS}

ABREU, J. B. R. Produção e nutrição dos capins Tanzânia-1 e Marandu em função de estádios de crescimento e adubação nitrogenada. Piracicaba, 1999. 103 p. Dissertação (Mestrado) - Escola Superior de Agricultura "Luiz de Queiroz", Universidade de São Paulo.

ABREU, C. A. de; ABREU, M. F.; RAIJ, B. VAN; BATAGLIA, O. C.; ANDRADE, J. C. de. Extraction of boron from soil by microwave heating for ICP-AES determination. Communications in Soil Science and Plant Analysis, v. 25, p. 3321-3333, 1994.

ALMEIDA, E. X.; MARASCHIN, G. E.; HARTHMANN, O. E. L. et al. Oferta de forragem de capim-Elefante anão Mott e o rendimento animal. Revista Brasileira de Zootecnia, v. 29, n. 5, p. 1288-1295, 2000.

AMBROSANO, E. J.; CORSI, M.; TRIVELIN, P. C. O.; AMBROSANO, G. M. B. Aproveitamento do nitrogênio do sulfato de amônio $\left({ }^{15} \mathrm{~N}\right)$ pelo capimcolonião em sucessivos cortes e diferentes épocas de adubação. Revista Brasileira de Ciência do Solo, v. 20, n. 2, p. 277-282, 1996.

ANDRADE, A. C.; FONSECA, D. M.; GOMIDE, J. A.; AlVAREZ, V. H.; MARTINS, C. E.; SOUZA, D. P. H. Produtividade e valor nutritivo do capim Elefante cv. Napier sob doses crescentes de nitrogênio e potássio. Revista Brasileira de Zootecnia, v. 29, n. 6, p. 1589-1595, 2000. 
ANDRADE, J. B.; PAULINO, V. T.; FERRARI JÚNIOR, E. et al. Resposta de Panicum maximum à fertilização nitrogenada e potássica. In: REUNIÃO ANUAL DA SOCIEDADE BRASILEIRA DE ZOOTECNIA, 33., Fortaleza, 1996. Anais. Fortaleza: Sociedade Brasileira de Zootecnia, 1996, p. 280-282.

ANGELES, D. E.; SUMNER, M. E.; BARBOUR, N. W. Preliminary nitrogen, phosphorus and potassium DRIS norms for pineapple. HortScience, v. 25, n. 6, p. 652-655, 1990.

ARMELI, M. J. A.; PRIMAVESI, O.; PIASENTIN, R. M.; DA SILVA, A. G. Estudo comparativo das concentrações de $\mathrm{Ca}, \mathrm{Cl}, \mathrm{K}, \mathrm{Mg}, \mathrm{Mn}$ e $\mathrm{Na}$ em algumas gramíneas forrageiras cultivadas em diferentes tipos de solo. In: REUNIÃO ANUAL DA SOCIEDADE BRASILEIRA DE ZOOTECNIA, 38., Piracicaba, 2001. Anais. Piracicaba: Sociedade Brasileira de Zootecnia, 2001. p. 1134-1136.

ASSOCIAÇÃO BRASILEIRA DAS INDÚSTRIAS EXPORTADORAS DE CARNES. http://www.abiec.com.br (10 fev. 2004).

BAILEY, D. W.; WELLING, G. R. Modification of cattle grazing distribution with dehydrated molasses supplement. Journal of Range Management, v. 52, p. 575-582, 1999.

BAILEY, J. S.; BEATTIE, J. A. M.; KILPATRICK, D. J. The diagnosis and recommendation integrated system (DRIS) for diagnosing the nutrient status of grassland swards: I. Model establishment. Plant and Soil, v. 197, n. 1, p. 127-135, 1997a.

BAILEY, J. S.; CUSHNAHAN, A.; BEATTIE, J. A. M. The diagnosis and recommendation integrated system (DRIS) for diagnosing the nutrient status of grassland swards: II. Model calibration and validation. Plant and Soil, v. 197, n. 1, p. 137-147, 1997b. 
BAILEY, J. S.; DILS, R. A.; FOY, R. H.; PATTERSON, D. The diagnosis and recommendation integrated system (DRIS) for diagnosing the nutrient status of grassland swards: III. Practical applications. Plant and Soil, v. 222, n. 1, p. 255-262, 2000.

BALDOCK, J. O., SCULTE, E. E. Plant analysis with standardized scores combines DRIS and sufficiency range approaches for corn. Agronomy Journal, v. 88, p. 448-456, 1996.

BALSALOBRE, M. A. A. Valor alimentar do capim Tanzânia irrigado. Piracicaba, 2002. 113 p. Tese (Doutorado) - Escola Superior de Agricultura "Luiz de Queiroz", Universidade de São Paulo.

BARBOSA, R. A.; NASCIMENTO JUNIOR, D.; EUCLIDES, V. P. B.; REGAZZI, A. J.; FONSECA, D. M. Características morfogênicas e acúmulo de forragem do capim Tanzânia (Panicum maximum Jacq. Cv. Tanzânia) em dois resíduos forrageiros pós-pastejo. Revista Brasileira de Zootecnia, v. 31, n. 2, p. 583-593, 2002.

BARROW, N. J. Return of nutrients by animals. In: SNAYDON, R. W. (Ed.). Ecosystems of the World - Managed Grasslands. Amsterdam: Elsevier, 1987. p. 181-186.

BATAGLIA, O. C.; SANTOS, W. R. dos. Efeito de procedimentos de cálculo e da população de referência nos índices do sistema integrado de diagnose e recomendação (DRIS). Revista Brasileira de Ciência do Solo, v. 14, p. 339-344, 1990.

BATAGLIA, O. C.; FURLANI, A. M. C.; TEIXEIRA, J. P. F.; FURLANI, P. R.; GALLO, J. R. Métodos de análises químicas de plantas. Campinas: Instituto Agronômico, 1983. 48 p. (Boletim Técnico, 78).

BEAUFILS, E. R. Research for rational exploitation of Hevea using a physiological based on the mineral analysis of various parts of the plants. Fertilite, v. 3, p. 27-38, 1957. 
BEAUFILS, E. R. Physiological diagnosis: a guide for improving maize production based on principles developed for rubber trees. Fertilizer Society South African Journal, v. 1, p. 1-28, 1971.

BEAUFILS, E. R. Diagnosis and recommendation integrated system (DRIS). Pietermaritizburg: University of Natal, South Africa, 1973. 132 p.

BELARMINO, M. C. J. Rendimento e qualidade de forragem de Panicum maximum Jacq. cv. Tanzânia em função da aplicação de superfosfato simples e sulfato de amônio. Lavras, 2001. 94 p. Dissertação (Mestrado) Universidade Federal de Lavras.

BENETTI, I.; MONTEIRO, F. A. Doses de potássio na produção e composição química do capim-Vencedor. In: SIMPÓSIO DE INICIAÇÃO CIENTÍFICA DA UNIVERSIDADE DE SÃO PAULO, 7., Piracicaba, 1999. Anais. Piracicaba: ESALQ, 1999. p. 314.

BEVERLY, R. B. Comparison of DRIS and alternative nutrient diagnostic methods for soybean. Journal of Plant Nutrition, v. 10, n. 8, p. 901-920, 1987.

BEVERLY, R. B. DRIS diagnoses of soybean nitrogen, phosphorus and potassium status are unsatisfactory. Journal of Plant Nutrition, v. 16, n. 8 , p. 1431-1447, 1993a.

BEVERLY, R. B. Re-evaluation reveals weaknesses of DRIS and sufficiency range diagnoses for wheat, corn and alfalfa. Communications in Soil Science and Plant Analysis, v. 24, n. 5, p. 487-501, 1993b.

BEVERLY, R. B.; STARK, J. C.; OJALA, J. C.; EMBLETON, T. W. Nutrient diagnosis of "Valencia" oranges by DRIS. Journal American Society for Horticultural Science, v. 109, n. 5, p. 649-654, 1984.

BHARGAVA, B. S.; RAGHUPATHI, H. B. Current status and new norm of calcium for grapevines. Journal of the Indian Society of Soil Science, v. 44, n. 1, p. 106-111, 1996. 
BRAZ, S. P.; NASCIMENTO JUNIOR, D.; CANTARUTTI, R. B.; RAGAZZI, A. J.; MARTINS, C. E.; FONSECA, D. M. Reciclagem de nutrientes pelas fezes de bovinos sob pastejo em pastagem de Brachiaria decumbens 1. Aspectos quantitativos. In: REUNIÃO ANUAL DA SOCIEDADE BRASILEIRA DE ZOOTECNIA, 38., Piracicaba, 2001. Anais. Piracicaba: Sociedade Brasileira de Zootecnia, 2001. p. 22-25.

CAMINHA, F. O.; RIBEIRO, F. L. F.; ANDRADE, F. M. E.; SILVA, S. C. Ganho de peso, taxa de lotação e capacidade de suporte das pastagens de capim Marandu submetido a regimes de lotação contínua por bovinos de corte. In: SIMPÓSIO INTERNACIONAL DE INICIAÇÃO CIENTÍFICA DA UNIVERSIDADE DE SÃO PAULO, 10., Piracicaba, 2002. Resumos. Piracicaba: SICUSP, 2002. v. 1. p. 138.

CANTARUTTI, R. B. Dinâmica de nitrogênio em pastagens de Brachiaria humidicola em monocultivo e consorciada com Desmodium ovalifolium Cv. Itabela no sul da Bahia. Viçosa, 1996. 83 p. Tese (Doutorado) - Universidade Federal de Viçosa.

CARVALHO, S. R. Influência de dois sistemas de manejo de pastagens na compactação de uma Terra Roxa Estruturada. Piracicaba, 1976. 89 p. Dissertação (Mestrado) - Escola Superior de Agricultura "Luiz de Queiroz", Universidade de São Paulo.

CASTILLA, C. E.; AYARZA, M. A.; SÁNCHEZ, P. A. Carbon and potassium dynamics in grass/legume grazing systems in the Amazon. In: POWELL, J. M.; RIVERA, S. F.; WILLIAMS T. O.; RENARD, C. (Ed.). Livestock and sustainable nutrient cycling. Addis Ababa: ILCA, 1995. p. 141-170.

CATANI, R. A.; GALLO, J. R. Avaliação de exigência em calcário dos solos do Estado de São Paulo mediante correlação entre $\mathrm{pH}$ e a porcentagem de saturação em bases. Revista de Agricultura, v. 30, p. 49-60, 1955. 
CECATO, U.; REGO, F. C. A.; CANTO, M.; RIBAS, N.; ALMEIDA JUNIOR., J; PETERNELLI, M. Conteúdo de minerais do capim Tanzânia manejado em diferentes alturas, sob pastejo. In: REUNIÃO ANUAL DA SOCIEDADE BRASILEIRA DE ZOOTECNIA, 38., Piracicaba SP, 2001. Anais. Piracicaba: SBZ, 2001. p. 120-121.

CENTRO DE ESTUDOS AVANÇADOS EM ECONOMIA APLICADA. http://www.cepea.esalq.usp.br (10 dez. 2003).

CHAPMAN D. F.; LEMAIRE G. Morphogenetic and structural determinants of plant regrowth after defoliation. In: BECKER R. J. (Ed.). Grasslands for our world. Wellington: SIR, 1993. cap. 3. p. 55-64.

COLOZZA, M. T. Rendimento e diagnose foliar dos capins Aruana e Mombaça cultivadas em latassolo vermelho-amarelo. Piracicaba, 1998. 127 p. Tese (Doutorado) - Escola Superior de Agricultura "Luiz de Queiroz", Universidade de São Paulo.

CONFEDERAÇÃO DA AGRICULTURA E PECUÁRIA DO BRASIL. http://www.cna.org.br (01 nov. 2003).

CORREAA, B. D. Doses de nitrogênio e de magnésio afetando aspectos bioquímicos dos capins Colonião, Tanzânia-1 e Vencedor. Piracicaba, 1996. 76 p. Dissertação (Mestrado) - Escola Superior de Agricultura "Luiz de Queiroz", Universidade de São Paulo.

CORRÊA, L. A. Níveis críticos de fósforo para estabelecimento de Brachiaria decumbens Stapf., Brachiaria brizantha (Hochst.) Stapf. Cv. Marandu e Panicum maximum Jacq., em latossolo vermelho amarelo, álico. Piracicaba, 1991. 83 p. Tese (Doutorado) - Escola Superior de Agricultura "Luiz de Queiroz", Universidade de São Paulo.

CORRÊA, L. A.; FREITAS, A. R.; EUCLIDES V. P. B. Níveis críticos de fósforo para estabelecimento de quatro cultivares de Panicum maximum em latossolo vermelho-amarelo, álico. In: REUNIÃO ANUAL DA SOCIEDADE BRASILEIRA DE ZOOTECNIA, 33., Fortaleza, 1996. Anais. Fortaleza: Sociedade Brasileira de Zootecnia, 1996. p. 169-170. 
CORSI, M.; NUSSIO L. G. Manejo do capim Elefante: correção e adubação do solo. In: SIMPÓSIO SOBRE O MANEJO DA PASTAGEM, 10., Piracicaba, 1994. Anais. Piracicaba: FEALQ, 1994. p. 87-116.

CORSI, M.; MARTHA JÚNIOR, G. B. Manutenção da fertilidade do solo em sistemas intensivos de pastejo rotacionado. In: SIMPÓSIO SOBRE O MANEJO DA PASTAGEM, 14., Piracicaba, 1999. Anais. Piracicaba: FEALQ, 1999. p. 161-192.

COUTINHO, E. M.; RODRIGUES, L. R. A.; CONSOLONI, F.; SCATOLIN, M.; NATALE, W. Efeitos da adubação nitrogenada e potássica na produção de matéria seca e na composição mineral do capim Coastcross irrigado. In: REUNIÃO ANUAL DA SOCIEDADE BRASILEIRA DE ZOOTECNIA, 38., Piracicaba, 2001. Anais. Piracicaba: Sociedade Brasileira de Zootecnia, 2001. p. 947-950.

CRESTE, J. E.; NAKAGAWA, J. Estabelecimento do método DRIS para a cultura do limoeiro em função da análise foliar; 1: cálculo das normas. Revista Brasileira de Fruticultura, v. 19, n. 3, p. 297-305, 1997.

CRESTE, J. E.; GRASSI FILHO, H. Estabelecimento de curvas de produtividade para três variedades e dois porta-enxertos cítricos na região sudoeste do Estado de São Paulo, com ênfase ao DRIS. In: CONGRESSO BRASILEIRO DE FRUTICULTURA, 15., Poços de Caldas, 1998. Resumos. Poços de Caldas: Sociedade Brasileira de Fruticultura, 1998. v. 1, p. 299.

CUNHA, J. F. O DRIS da Potafos. In: SIMPÓSIO SOBRE ROTAÇÃO SOJA/MILHO NO PLANTIO DIRETO, 2., Piracicaba, 2001. Anais. Piracicaba: Potafos, 2001. p. 302.

DA SILVA, S. C.; PEDREIRA, C. G. S. Princípios de ecologia aplicados ao manejo de pastagem. In: SIMPÓSIO SOBRE ECOSSISTEMAS DE PASTAGENS, 3., Jaboticabal, 1997. Anais. Jaboticabal: FUNEP, 1997. p. 1-62. 
DA SILVA, A. P.; TORMENA, C. A.; MAZZA, J. A. Manejo físico de solos sob pastagem. In: SIMPÓSIO SOBRE O MANEJO DA PASTAGEM, 14., Piracicaba, 1999. Anais. Piracicaba: FEALQ, 1999. p. 25-38.

DA SILVA, A. P.; IMHOFF, S.; CORSI, M. Evaluation of soil compaction in an irrigated short-duration grazing system. Soil and Tillage Research, v. 70, n. 1, p. 83-90. Mar. 2003.

DA SILVA, A. P.; IMHOFF, S.; CORSI, M. Soil compaction versus cow-stocking rates on an irrigated grazing system. Soil and Tillage Research. 2004. (No prelo).

DAVEY, B. J.; CONYERS, M. K. Determining the pH of acids soils. Soil and Science, v. 146, n. 3, p. 141-150, 1988.

DAVIES, A. The regrowth of grass swards. In: JONES M. B.; LAZEMBY A. (Ed.). The physiological basis of production. London: Chapman and Hall, 1988. p. 85-127.

DAVIES, A. W.; ADAMS, A.; WILMAN, D. Soil compaction on permanent pasture and its amelioration by slitting. Journal of Agricultural Science, n. 113, p. 189-197, 1989.

DIAS FILHO, M. B. Níveis críticos internos de fósforo de três acessos de Panicum maximum. Pasturas Tropicales, v. 17, n. 2, p. 9-11, 1995.

DIAS JUNIOR, M. S.; PIERCE, F. J. O processo de compactação do solo e sua modelagem. Revista Brasileira de Ciência do Solo, v. 20, p. 172-175, 1996.

ELWALI, A. M. O.; GASCHO, G. J. Soil testing, foliar analysis, and DRIS as guide for sugarcane fertilization. Agronomy Journal, v. 76, p. 466-470, 1984.

FALADE, J. A. The effect of phosphorus on growth and mineral composition of five tropical grasses. East African Agricultural and Forest Journal, v. 41, n. 4, p. 342-350, apr. 1975. 
FAQUIN, V.; NETO, J. F.; EVANGELISTA, A. R. et al. Limitações nutricionais do colonião (Panicum maximum Jacq.), e da Braquiária (Brachiaria decumbens Staff) em amostras de um latossolo do noroeste do Paraná: II Nutrição mineral em macro e micronutrientes. Revista Brasileira de Zootecnia, v. 23, n. 4, p. 552-565,1994.

FAQUIN, V.; PASSOS, R. R.; CURI, N.; VILLA, M. R.; EVANGELISTA A. R. Absorção e acumulação de nutrientes por gramíneas forrageiras sob influência de fontes de fósforo e correção do solo. Revista Brasileira de Zootecnia, v. 26, n. 2, p. 219-226, 1997.

FARIA, V. P. de.; PEDREIRA, C. G. S.; SANTOS, F. A. P. Evolução do uso de pastagens para bovinos. In: SIMPÓSIO SOBRE MANEJO DA PASTAGEM, 13., Piracicaba, 1997. Anais. Piracicaba: FEALQ, 1997. p. 1-14.

FERRARI NETO, J. Limitações nutricionais para o colonião (Panicum maximum Jacq.) em latossolo da região noroeste do Estado do Paraná. Lavras, 1991. 126 p. Dissertação (Mestrado) - Escola Superior de Agricultura de Lavras.

FERRARI NETO, J.; FAQUIN, V.; DO VALE, F. R.; EVANGELISTA, A. R. Limitações nutricionais do colonião (Panicum maximum Jacq.), e da braquiária (Brachiaria decumbens Staff) em amostras de um latossolo do noroeste do Paraná: I Produção de matéria seca e perfilhamento. Revista Brasileira de Zootecnia, v. 23, n. 4, p. 538-551,1994.

FRANÇA, A. F. S.; HAAG, H. P. Nutrição mineral de gramíneas tropicais. Carências nutricionais de capim-Tobiatã (Panicum maximum Jacq.). Anais da Escola Superior de Agricultura "Luiz de Queiroz", v. 62, p. 38-95, 1985.

FOX, D. G; TYLUTKI, T. P.; VAN AMBURGH, M. E. et al. The net carbohydrate and protein system for evaluating herd nutrition and nutrient excretion. New York: CNCPS, version 4.0, 2000. 
GALLO, J. R.; HIROCE, R.; BATAGLIA, O. C.; FURLANI, P. R.; FURLANI, A. M. C.; MATTOS, H. B.; SARTINI, H. J.; FONSECA, M. P. Composição inorgânica de forrageiras do Estado de São Paulo. Boletim da Indústria Animal, v. 31, p. 115-137, 1974.

GARCEZ NETO, A. F.; NASCIMENTO JUNIOR, D.; REGAZZI, A. J.; FONSECA, D. M.; MOSQUIM, P. R.; GOBBI, K. F. Respostas morfogênicas e estruturais de Panicum maximum cv. Mombaça sob diferentes níveis de adubação nitrogenada e alturas de corte. Revista Brasileira de Zootecnia, v. 31, n. 5, p. 1890-1900, 2002.

GEE, G. W.; BAUDER, J. W. Particle size analysis. In: KLUTE, A. Methods of soil analysis. Madison: American Society of Agronomy, 1986. p. 383-412.

GOMIDE, J. A. Adubação fosfatada e potássica de plantas forrageiras. In: PEIXOTO, A. M.; MOURA, J. C.; FARIA, V. P. (Ed.). Pastagens fundamentos da exploração racional. Piracicaba: FEALQ, 1986. p. 155-164.

GONÇALVES, A. C. Características morfogênicas e padrão de desfolhação em pastagens de capim marandu submetidas a regimes de lotação contínua. Piracicaba, 2002. 124 p. Dissertação (Mestrado) - Escola Superior de Agricultura "Luiz de Queiroz", Universidade de São Paulo.

HAAG, H. P.; DECHEN, A. R. Deficiências minerais em plantas forrageiras. In: PEIXOTO, A. M.; MOURA, J. C.; FARIA, V. P. (Ed.). Pastagens fundamentos da exploração racional. Piracicaba: FEALQ, 1994. p. 85-110.

HALLMARK, W. B.; BEVERLY, R. B.; MORRIS, H. F. JUNIOR.; WALL, D. A. Modification of the M-DRIS for soybean. Communications in Soil Science and Plant Analysis, v. 25, n. 7, p. 1085-1101, 1994.

HALLMARK, W. B.; BEVERLY, R. B. Review: an update in the use of the diagnosis and recommendation integrated system. Journal of fertilizer Issues, v. 8, n. 3, p. 74-88, 1991 
HAYNES, R. J.; WILLIAMS, P. H. Nutrient cycling and soil fertility in the razed pasture ecosystem. Advanced Agronomy, v. 49, p. 119-199, 1993.

HODGSON, J. Grazing management: science into practice. Essex: Longman Scientific and Technical, 1990. 203 p.

HODGSON, J.; BIRCHAM, J. S.; GRANT, S. A.; KING, J. The influence of cutting and grazing management on herbage growth and utilization. In: PLANT PHISIOLOGY AND HERBAGE PRODUCTION, Occasional Symposium, 13., Belfast, 1981. Anais. Belfast: British Grassland Society, 1981, p. 51-62.

HOFFMANN, C. R. Nutrição mineral e crescimento da braquiária e do colonião, sob influência das aplicações de nitrogênio, fósforo, potássio e enxofre em latossolo da região noroeste do Paraná. Lavras, 1992. 204 p. Dissertação (Mestrado) - Escola Superior de Agricultura de Lavras.

HOFFMANN, C. R.; FAQUIN, V.; GUEDES, G. A. A.; EVANGELISTA, A. R. O nitrogênio e o fósforo no crescimento da Braquiária e do colonião em amostras de um latossolo da região noroeste do Paraná. Revista Brasileira de Ciência do Solo, v. 19, n. 1, p. 79-86, 1995.

IGARASI, M. S. Controle de perdas na ensilagem de capim Tanzânia (Panicum maximum Jacq.) sob os efeitos de teor de matéria seca, do tamanho de partícula, da estação do ano e da presença do inoculante bacteriano. Piracicaba, 2002. 113 p. Dissertação (Mestrado) - Escola Superior de Agricultura "Luiz de Queiroz", Universidade de São Paulo.

INSTITUTO DE ECONOMIA AGRÍCOLA

http://www.iea.sp.gov.br (10 nov. 2002).

JONES, C. A. Proposed modifications of the diagnosis and recommendation integrated system (DRIS) for interpreting plant analysis. Communications in Soil Science and Plant Analysis, v. 12, n. 8, p. 785-794, 1981.

LAVRES JUNIOR, J. Combinações de doses de nitrogênio e potássio para o capim Mombaça. Piracicaba, 2001. 103 p. Dissertação (Mestrado) - Escola Superior de Agricultura "Luiz de Queiroz", Universidade de São Paulo. 
LEITE, R de A. Avaliação do estado do cafeeiro Conilon no Estado do Espírito Santo utilizando diferentes métodos de interpretação de análise foliar. Viçosa, 1992. 87 p. Tese (Doutorado) - Universidade Federal de Viçosa.

LETZSCH, W. S. Computer program for selection of norms for use in the diagnosis and recommendation integrated system (DRIS). Communications in the Soil Science and Plant Analysis, v. 16, p. 339-347, 1985.

LINDSAY, W. L.; NORVELL, W. A. Development of DTPA soil for zinc, iron, manganese and copper. Soil Science of American Journal, v. 42, p. 421428, 1978.

LIRA, M. A.; DUBEUX JUNIOR., J. C. B.; FERNANDES, A. P. M.; FARIAS, I. Estudo da estabilidade de produção do capim Pangola (Digitaria decumbens Stent), submetido a adubações nitrogenada e fosfatada. Revista da Sociedade Brasileira de Zootecnia, v. 23, n. 3, p. 402-411, 1994.

LOURENÇO, L. F.; COELHO, L. D.; SORIA, L. G. T.; PINHEIRO, V. D.; CORSI, M. Coeficiente de cultura do capim Tanzânia (Panicum maximum) irrigado por pivô central. In: REUNIÃO ANUAL DA SOCIEDADE BRASILEIRA DE ZOOCTENIA. 38., Piracicaba, 2001. Anais. Piracicaba: SBZ, 2001. p. 316-317.

MALAVOLTA, E. ABC da adubação, 5. ed. São Paulo: Ceres, 1989. 292 p.

MALAVOLTA, E.; VITTI, G. C.; OLIVEIRA, S. A. Avaliação do estado nutricional das plantas: princípios e aplicações. 2. ed. Piracicaba: POTAFOS, 1997. $319 \mathrm{p}$.

MANARIN, C. A. Respostas fisiológicas, bioquímicas e produtivas do capimMombaça a doses de nitrogênio. Piracicaba, 2000. 58 p. Dissertação (Mestrado) - Escola Superior de Agricultura "Luiz de Queiroz", Universidade de São Paulo.

MARCELINO, K. R. A.; FONSECA, D. M. Reciclagem de nutrientes sob condições de pastejo. Tópicos Especiais em Forragicultura. Viçosa, 2002. Departamento de Zootecnia. Universidade Federal de Viçosa. 2002. 29 p. 
MARSCHNER, H. Mineral nutrition in higher plants. Orlando: Academic Press, 1986. $673 \mathrm{p}$.

MARTHA JUNIOR, G. B. Balanço de $\left({ }^{15} \mathrm{~N}\right)$ e perdas de amônia por volatilização em pastagens de capim-Elefante. Piracicaba, 1999. 75 p. Dissertação (Mestrado) - Escola superior de Agricultura "Luiz de Queiroz", Universidade de São Paulo.

MARTIM, R. A. Doses de nitrogênio e de potássio para a produção e composição dos capins Coastross-1 e Tifton 85 em um Latossolo VermelhoAmarelo. Piracicaba, 1997. 109 p. Dissertação (Mestrado) - Escola Superior de Agricultura "Luiz de Queiroz" Universidade de São Paulo.

MARTINEZ, H. E. P. Níveis críticos de fósforo em Brachiaria decumbens (Stapf) Prain, Brachiaria humidicola (Rendle) Schweicherdt, Digitaria decumbens Stent, Hyparrhenia rufa (Ness Stapf), Melinis minutiflora Pal de Beauv, Panicum maximum Jacq. e Pennisetum purpureum Schum. Piracicaba, 1980. 90 p. Dissertação (Mestrado) - Escola Superior de Agricultura "Luiz de Queiroz"; Universidade de São Paulo.

MATHEWS, B. W.; SOLLENBERGER, L. E.; TRITSCHLER, J. P. Grazing systems and spatial distribution of nutrients in pastures - soil considerations. In: JOOST R. E.; ROBERTS, C. A. (Ed.). Nutrient cycling in forage systems. Columbia: University of Missouri PPI, 1996. p. 213-229.

MATHEWS, B. W.; SOLLENBERGER, L. E.; NAIR, V. D.; STAPLES, C. R. Impact of grazing management on soil nitrogen, phosphorus, potassium and sulfur distribution. Journal Environmental Quality, v. 23, p. 1006-1013, 1994.

MATTHEWS, C. A study of seasonal root and tiller dynamic in sward of perennial ryegrass (Lolium perenne, L.) Palmerston North, 1992. 247 p. Thesis (Ph. D.) - Massey University.

MATTOS, H. B.; WERNER, J. C. Efeitos de nitrogênio mineral de leguminosas sobre a produção de capim-Colonião (Panicum maximum Jacq.) Boletim da Indústria Animal, v. 36, p. 147-156, 1979. 
MATTOS, W. T.; MONTEIRO, F. A. Concentração de magnésio nas partes da Brachiaria decumbens submetida a doses de potássio. In: REUNIÃO BRASILEIRA DE FERTILIDADE DO SOLO E NUTRIÇÃO DE PLANTAS, 23., Caxambu, 1998. Resumos. Lavras: Universidade Federal de Lavras, 1998. p. 278.

MAYA, F. L. A. Produtividade e viabilidade econômica da recria e engorda de bovinos em pastagens adubadas intensivamente com e sem o uso da irrigação. Piracicaba, 2003. 83 p. Dissertação (Mestrado) - Escola Superior de Agricultura "Luiz de Queiroz", Universidade de São Paulo.

MAYS, D. A.; WILKINSON, S. R.; COLE, C. V. Phosphorus nutrition of forages. In: KHASAWNEH, S. E.; SAMPLE, E. C. KAMPRATH, E. J. (Ed.). The role of phosphorus in agriculture. Madison, WI: SAC, 1980. p. 805-846.

MESA, A. R.; MENDOZA, F.; AVILA, V. Rendimiento, composición química y niveles críticos de potasio en cuatro gramíneas tropicales. Pastos y Forrajes, v. 12, p. 43-51, 1989.

MIDDLETON, K. R.; SMITH, G. S. The concept of a climax in relation to the fertiliser input of a pastoral ecosystem. Plant and Soil, v. 50, p. 595-614. 1978.

MINISTÉRIO DA AGRICULTURA, PECUÁRIA E ABASTECIMENTO. http://www.agricultura.org.br (10 jan. 2004).

MONTEIRO, F. A.; CARRIEL, J. M. Aplicação de níveis de enxofre na forma de gesso para cultivo do capim colonião em dois solos arenosos do Estado de São Paulo. Boletim da Indústria Animal, v. 44, n. 2, p. 335-347. Jun. 1987.

MONTEIRO, F. A.; WERNER, J. C. Reciclagem de nutrientes nas pastagens. In: SIMPÓSIO SOBRE MANEJO DA PASTAGEM, 14., Piracicaba, 1999. Anais. Piracicaba: FEALQ, 1999. p. 55-84.

MONTEIRO, F. A.; LIMA S. A. A.; WERNER, J. C. et al. Adubação potássica em leguminosas e em capim-colonião (Panicum maximum Jacq.) adubado com níveis de nitrogênio ou consorciado com leguminosas. Boletim da Indústria Animal, v. 37, n. 1, p. 127-147, 1980. 
MONTEIRO, F. A.; RAMOS, A. K. B.; CARVALhO, D. D. et al. Cultivo de Brachiaria brizantha Stapf. Cv. Marandu em solução nutritiva com omissões de nutrientes. Scientia Agrícola, v. 52, n. 1, p. 135-141, 1995.

MONTEIRO, F. A.; FRARE, P. M.; ONO, M. N. Magnésio, cálcio e potássio no tecido foliar de Brachiaria decumbens submetida a doses de magnésio. In: REUNIÃO BRASILEIRA DE FERTILIDADE DE SOLO E NUTRIÇÃO DE PLANTAS, 23., Lavras, 1998. Resumos. Lavras: UFLA, 1998. p. 532.

MONTEIRO, F. A.; MATTOS, W. T.; SCHIAVUZZO, P. F. Zinco e manganês na parte aérea de Braquiária Marandu. In: SIMPÓSIO INTERNACIONAL GRASSLAND ECOPHYSIOLOGY AND GRAZING ECOLOGY, Curitiba, 1999. Anais. Curitiba: UFPR, 1999. p. 333-335.

MONTEIRO, F. A.; RODRIGUES, L. R. A.; WERNER, J. C. Forrageiras. In: FERREIRA, M. E.; DA CRUZ, M. C. P.; RAIJ, B. V.; ABREU, C. A. (Ed.). Micronutrientes e elementos tóxicos na agricultura. Jaboticabal: CNPq, FAPESP, POTAFOS, 2001. p. 375-390.

MOTT, G. O. Nutrient recycling in pastures. In: MAYS, D. A. (Ed.). Forage fertilization. Madison, WI: American Society of Agronomy, 1974. p. 323-339. MOURÃO FILHO, F. A. A.; AZEVEDO, J. C.; NICK, J. A. Funções e ordem da razão dos nutrientes no estabelecimento de normas DRIS em laranja "Valência". Pesquisa Agropecuária Brasileira, v. 37, n. 2, p. 185-192. Fev. 2002.

MOURÃO FILHO, F. A. A. DRIS: Um método alternativo para avaliação do estado nutricional em citros. In: SEMINÁRIO INTERNACIONAL DE CITROS, PRODUÇÃO INTEGRADA, 6. Bebedouro, 2000. Anais. Bebedouro: Fundação Cargill, 2000. p. 36-66.

MUNSON, R. D.; NELSON, W. L. Principles and practices in plant analysis. In: WALSH, L. M.; BEATON, J. D. (Ed.). Soil testing and plant analysis. Madison: Soil Science Society of America, 1973. p. 223-248. 
MYERS, R. J. K.; PALM, C. A.; CUEVAS, E.; GUNATILLIKE, I. U. N.; BROSSARD, M. The synchronization of nutrient mineralisation and plant nutrient demand. In: WOOMER, P. L.; SWIFT, M. J. (Ed.). The biological management of tropical soil fertility. New York: WS, 1994. p. 81-116.

NABINGER, C. Eficiência do uso de pastagens: Disponibilidade e perdas de forragem. In: SIMPÓSIO SOBRE O MANEJO DA PASTAGEM, 14., Piracicaba, 1999. Anais. Piracicaba: FEALQ, 1999. p. 213-252.

NICK, J. A. DRIS para cafeeiros podados. Piracicaba, 1998. 86 p. Dissertação (Mestrado) - Escola Superior de Agricultura "Luiz de Queiroz", Universidade de São Paulo.

PAGOTTO, D. S. Comportamento do sistema radicular do capim Tanzânia (Panicum maximum Jacq.) sob irrigação e submetido a diferentes intensidades de pastejo. Piracicaba, 2001. 51 p. Dissertação (Mestrado) Escola Superior de Agricultura "Luiz de Queiroz", Universidade de São Paulo.

PARSONS, A. J.; HARVEY, A.; WOLEDGE, J. Plant-animal interaction in a continuously grazed mixture. I. Differences in the physiology of leaves of grass and clover. Journal of Applied Ecology, v. 28, p. 619-634, 1991.

PENATI, M. A. Estudo do desempenho animal e produção do capim Tanzânia (Panicum maximum Jacq.) em um sistema rotacionado de pastejo sob irrigação em três níveis de resíduo pós-pastejo. Piracicaba, 2002. 117 p. Tese (Doutorado) - Escola Superior de Agricultura "Luiz de Queiroz", Universidade de São Paulo.

PENATI, M. A.; CORSI, M.; DIAS, C. T. S.; MAYA, F. L. Efeito do número de amostras e da relação dimensão-formato da moldura sobre o coeficiente de variação na determinação da massa de forragem em pastagens de capim Tanzânia. In: REUNIÃO ANUAL DA SOCIEDADE BRASILEIRA DE ZOOTECNIA, 38., Piracicaba, 2001. Anais. Piracicaba: SBZ, 2001. p. 46-47. 
PEREIRA, W. L. M. Doses de potássio e de magnésio em solução nutritiva para capim Mombaça. Piracicaba, 2001. 124 p. Tese (Doutorado) - Escola Superior de Agricultura "Luiz de Queiroz", Universidade de São Paulo.

PETERSON, P. R.; GERRISH, J. R. Grazing systems and spatial distribution of nutrients in pastures: livestock management considerations. In: JOOST, R. E.; ROBERTS, C. A. (Ed.). Nutrient cycling in forage systems. Columbia: University of Missouri, 1996. p. 203-212.

PETERSON, R. A. O fator água. In: FUNDAMENTOS DO MANEJO EM PASTAGENS. São Paulo, 1970. Anais. São Paulo: Secretaria de Agricultura Coordenadoria de Pesquisa Agropecuária, 1970. p. 63-75.

PRIMAVESI, A. C; CORRÊA, L. A.; CANTARELLA, H.; PRIMAVESI, O.; FREITAS, A. R.; da SILVA, A. G. Eficiência nutricional de dois adubos nitrogenados aplicados a lanço em capim Coastcross (Cynodon dactylon $\mathrm{L}$. Pears). In: REUNIÃO ANUAL DA SOCIEDADE BRASILEIRA DE ZOOTECNIA, 38., Piracicaba, 2001. Anais. Piracicaba: Sociedade Brasileira de Zootecnia, 2001. p. 178-179.

PRIMAVESI, O.; CORREAA, L. de A.; PRIMAVESI, A. C.; CANTARELLA, H.; ARMELIN, M. J. A.; SILVA, H. G. de A.; FREITAS, A. R. Adubação com uréia em pastagem de Cynodon dactylon cv. Coastcross sob manejo rotacionado: eficiência e perdas. São Carlos, 2001. São Carlos: EMBRAPA Pecuária Sudeste. 2001, 42 p. (circular técnica, 30).

QUADROS, D. G.; RODRIGUES, L. R.; FAVORETTO, V.; MALHEIROS, E.; RAMOS, A. K. B. Perdas de forragem em pastagens dos cvs. Tanzânia e Mombaça de Panicum maximum Jacq. adubadas com quatro doses de N, P e K. In: REUNIÃO ANUAL DA SOCIEDADE BRASILEIRA DE ZOOTECNIA, 38., 2001. Piracicaba. Anais. FEALQ: Piracicaba, 2001. p. 294-296.

QUAGGIO, J. A.; RAIJ, B. van. Comparação de métodos rápidos para a determinação da matéria orgânica e solos. Revista Brasileira de Ciência do Solo, v. 3, p. 184-187, 1979. 
REIS JUNIOR. R. A. Diagnose nutricional da cana-de-açúcar com uso do sistema integrado de diagnose e recomendação (DRIS). Campos de Goytacazes, 1999. 141 p. Dissertação (Mestrado) - Universidade Estadual do Norte Fluminense.

REIS JÚNIOR, R. dos A.; CORRÊA, J. B.; CARVALHO J. G. de; GUIMARÃES, P. T. G. Estabelecimento de normas DRIS para o cafeeiro no Sul de Minas Gerais. $1^{a}$ aproximação. Ciência Agrotécnica, v. 26, n. 2, p. 269-282, 2002. RESENDE, C. P., CANTARUTTI, R. B.; BRAGA, J. M. et al. Litter deposition and disappearance in Brachiaria pastures in the atlantic forest region of the south of Bahia, Brazil. Nutrient Cycling In Agroecosystems, v. 54, p. 99112, 1999.

RIBEIRO, K. G.; GOMIDE, J. G.; PACIULLO, D. S. C. Adubação nitrogenada de capim Elefante cv. Mott. 2. Valor nutritivo ao atingir 80 e $120 \mathrm{~cm}$ de altura. Revista Brasileira de Zootecnia, v. 28, n. 6, p. 1194-1202, 1999.

RODRIGUES, A. C. G.; ROSSIELLO, R. O. P. Crescimento, absorção de K, Ca e $\mathrm{Mg}$ de forrageiras tropicais em função da absorção potássica. In: CONGRESSO BRASILEIRO DE CIÊNCIA DO SOLO, 25., Viçosa, 1995. Resumos. Viçosa: SBCS, 1995. p. 1252-1254.

ROSSI, C. Nutrição em fósforo e atividade da fosfatase ácida nos capins Braquiária e colonião. Piracicaba, 1999. 121 p. Tese (Doutorado) - Escola Superior de Agricultura "Luiz de Queiroz", Universidade de São Paulo.

RUSSELLE, M. P. Nutrient cycling in pasture. In: SIMPÓSIO INTERNACIONAL SOBRE PRODUÇÃO ANIMAL EM PASTEJO. Viçosa, 1997. Anais. Viçosa: Universidade Federal de Viçosa, 1997. p. 235-266.

RYDEN, J. C. Gaseous losses of nitrogen from grassland. In: VAN DER MEER, H. G. et al. (Ed.). Nitrogen fluxes in intensive grassland systems. Dordrecht: Martins Nijhoff Publishers, 1986. p. 59-74.

SANTOS, P. M. Controle do desenvolvimento das hastes no capim Tanzânia: Um desafio. Piracicaba, 2002. 98 p. Tese (Doutorado) - Escola Superior de Agricultura "Luiz de Queiroz", Universidade de São Paulo. 
SARRUGE, J. R.; HAAG, H. P. Análises químicas em plantas. Piracicaba: ESALQ, 1974. $57 \mathrm{p}$.

STATISTICAL ANALYSIS SYSTEM. SAS: user's guide statistics: version 8.0 edition. Cary, 1999. 956 p.

SAUNDERS, W. M. H. Mineral composition of soil and pasture from areas of grazed paddocks, affected and unaffected by dung and urine. New Zealand Journal of Agricultural Research, v. 27, p. 405-412, 1984.

SCHOFIELD, R. K.; TAYLOR, A. W. The measurement of soil pH. Soil Science Society of America Proceedings, v. 19, n. 2, p. 164-167, 1955.

SCHOMBERG, H. H.; STUEDEMANN, J. A.; FRANZLUEBBERS, A. J.; STANLEY, R. W. Spatial distribution of extractable phosphorus, potassium and magnesium as influenced by fertilizer and tall fescue endophyte status. Agronomy Journal, v. 92, sep. 2000. p. 981-986.

SILVA, A. A.; MATTOS, W. T.; MONTEIRO, F. A. Respostas de capim-Tanzânia - 1 (Panicum maximum Jacq.) a níveis de potássio em solução nutritiva. In: CONGRESSO BRASILEIRO DE CIÊNCIA DO SOLO, 25., VIÇOSA, 1995. Resumos. Viçosa: SBCS, 1995. p. 1046-1047.

SILVA, E. B.; NOGUEIRA, F. D.; GUIMARÃES, P. T. G. Uso do DRIS na avaliação do estado nutricional do cafeeiro em resposta à adubação potássica. Revista Brasileira de Ciência do Solo, v. 27, p. 247-255, 2003.

SILVA, S. C. Características morfofisiológicas e respostas funcionais de plantas forrageiras e animais submetidos a pastejo. Piracicaba, 2002. 487 p. Tese (Livre Docência) - Escola Superior de Agricultura "Luiz de Queiroz", Universidade de São Paulo.

SILVEIRA, C. P.; MONTEIRO, F. A.; NACHIGALL, G. R. DRIS para a forrageira Brachiaria decumbens. Relatório de estágio profissionalizante em Engenharia Agronômica. Piracicaba, 2003. 57 p. Escola Superior de Agricultura "Luiz de Queiroz", Universidade de São Paulo.

SKERMAN, P. J.; RIVEROS, F. Gramíneas tropicales. Rome: FAO, 1992. 849 p. (Colección FAO: Producción y Protección Vegetal, 23) 
SKINNER, R. H.; NELSON, C. J. Role of leaf appearance rate and coleoptile tiller in regulating production. Crop Science. v. 34, n. 1, p. 71-75, 1994.

SKINNER, R. H.; NELSON, C. J. Elongation of the grass leaf and its relationship to the phyllochron. Crop Science, v. 35, n. 1, p. 4-10, 1995.

SMITH, P. F. Mineral analysis of plant tissues. Annual Review of Plant Physiology, v. 13, p. 81-108, 1962.

SOARES, E. Influência do teor de potássio trocável do solo na absorção de cálcio e magnésio pela soja (Glycine max (L) Merril). Piracicaba, 1978. 116 p. Tese (Doutorado) - Escola Superior de Agricultura "Luis de Queiroz", Universidade de São Paulo.

SOLLENBERGER, L. E.; DUBEUX, J. C. B.; SANTOS, H. Q.; MATHEWS, B. W. Nutrient cycling in tropical pasture ecosystems. In: REUNIÃO ANUAL DA SOCIEDADE BRASILEIRA DE ZOOTECNIA, 39., Recife, 2002. Anais de Palestras. Recife: Sociedade Brasileira de Zootecnia, 2002. p. 151-179.

SÓRIA, L. G. T. Produtividade do capim-Tanzânia (Panicum maximum Jacq. cv.

Tanzânia) em função da lâmina de irrigação e de adubação nitrogenada. Piracicaba, 2002. 170 p. Tese (Doutorado) - Escola Superior de Agricultura "Luiz de Queiroz", Universidade de São Paulo.

SUMNER, M. E. Effect of corn leaf sampled on N, P, K, Ca and Mg content and calculated DRIS indices. Communications in Soil Science and Plant Analysis, v. 8, n. 3, p. 269-280, 1977.

SUMMER, M. E. Interpretation of foliar analysis for diagnostic purposes. Agronomy journal, v. 71, p. 343-348, 1979.

SUMNER, M. E. Application of Beaufils' diagnostic indices to corn data published in literature irrespective of age and conditions. Plant and Soil. v. 46, p. 359-363, 1997.

SUMNER, M. E.; RENEAU JUNIOR., R. B.; SCULTE, E. E.; AROGUM. J. O. Foliar diagnostic norms for sorghum. Communications in Soil Science and Plant Analysis, v. 14, n. 9, p. 817-825, 1983. 
TARPLEY, M. L.; ROBINSON, D. L.; GUSTAVSON, B. K.; EICHHORN JR.; M. M. The DRIS for interpretation of Coastal Bermuda grass analysis. Communications in Soil Science and Plant Analysis, v. 16, n. 12, p. 1335-1348, 1985.

THOMAS, R. J. The role of the legume in the nitrogen cycle of productive and sustainable pastures. Grass Forage Science, v. 47, p. 133-142, 1992.

THORNTON, B.; MILARD, P. The effect of nitrogen supply and defoliation on the seasonal internal cycling of nitrogen in Molinia caeruela. Journal of Experimental Botany, v. 44, p. 531-536, 1993.

TOSI, P. Estabelecimento de parâmetros agronômicos para o manejo e eficiência de utilização de Panicum maximum Jacq. cv. Tanzânia sob pastejo rotacionado. Piracicaba, 1999. 103 p. Dissertação (Mestrado) Escola Superior de Agricultura "Luiz de Queiroz", Universidade de São Paulo.

VAN RAIJ, B.; CANTARELLA, H.; QUAGGIO, J. A.; FURLANI, A. M. C. (Ed) Recomendações de adubação e calagem para o Estado de São Paulo. 2. ed. Campinas: IAC, 1997. 285 p. (Boletim Técnico, 100)

VAN RAIJ, B. Fertilidade do solo e adubação. Piracicaba: Potafos, 1991. 343 p. VELOSO, C. A. C.; GRAÇA, J. J da C.; GAMA, J. R. N. F. Estabelecimento do método DRIS para cultura de citros na mesorregião do nordeste do Estado do Pará. Revista Brasileira de Fruticultura, v. 22, n. 3, p. 372-376, 2000.

VICENTE-CHANDLER, J; PEARSON, R. W.; ABRUÑA, F. et al. Potassium fertilization of intensive managed grasses under humid tropical conditions. Agronomy Journal, v. 54, p. 450-453, 1962.

VITTI, G. C. Avaliação e interpretação do enxofre no solo e na planta. Jaboticabal: FUNEP, 1989. 37 p.

VITTI, G. C. Série de apostilas para o curso de Pós-Graduação em Ciência do Solo. Piracicaba, Departamento da Ciência do Solo/ESALQ, 1997. 40 p.

VITTI, G. C. Série de apostilas para o curso de Pós-Graduação em Ciência do Solo. Piracicaba, Departamento da Ciência do Solo/ESALQ, 2001. 60 p. 
WADT, P. G. S.; NOVAIS, R. F.; ALVAREZ-V., V. H.; BARROS, N. F.; DIAS, L. E. Uso de diferentes compartimentos da árvore nos índices DRIS e seus efeitos na avaliação da nutrição nitrogenada em eucaliptos. Revista Árvore, v. 23, n. 3, p. 271-277, 1999.

WALWORTH, J. L.; SUMNER, M. E. The diagnosis and recommendation integrated system (DRIS). Advances in Soil Sciences, v. 6, p. 149-188, 1987.

WALWORTH, J. L.; WOODDARD, H. J.; SUMNER, M. E. Generation of corn tissue norms from a small, high-yield data base. Communications in Soil Science and Plant Analysis, v. 19, p. 563-577, 1988.

WALWORTH, J. L.; SUMNER, M. E.; ISAAC, R. A.; PLANK, C. O. Preliminary DRIS norm for alfafa. Agronomy Journal, v. 78, p. 1046-1052, 1986.

WERNER, J. C. Estudos sobre a nutrição mineral de alguns capins tropicais. Piracicaba, 1971. 95 p. Tese (Doutorado) - Escola Superior de Agricultura "Luiz de Queiroz", Universidade de São Paulo.

WERNER, J. C.; MONTEIRO, F. A. Respostas das pastagens à aplicação de enxofre. In: ENXOFRE E MICRONITRIENTES NA AGRICULTURA BRASILEIRA, Londrina, 1988. Anais. Londrina: Embrapa, CNPS; IAPAR, 1988. p. 87-102.

WERNER, J. C.; MONTEIRO, F. A.; CARRIEL, J. M. Efeitos da calagem em capim Colonião (Panicum maximum Jacq.) estabelecido. Boletim da Indústria Animal, v. 36, p. 247-254, 1979

WERNER, J. C.; PAULINO, V. T.; CANTARELLA, H.; ANDRADE, N. O.; QUAGGIO, J. A. Forrageiras. Recomendações de adubação e calagem para o Estado de São Paulo. 2. ed. Campinas: IAC, 1997. 285 p. (Boletim Técnico, 100).

WILKINSON, R. R.; LOWREY, R. W. Cycling of mineral nutrients in pasture ecosystems. In: BUTLER, G. W.; BAILEY, R. W. (Ed.). Chemistry and biochemistry of herbage. London: Academic Press, 1973. v. 2, p. 247-315. 
WILLIAMS, P. H.; GREGG, P. E. H.; HEDLEY, M. J. Mass balance modeling of potassium losses from grazed dairy pasture. New Zealand Journal of Agricultural Research, v. 33, p. 661-668, 1990. 